Prepared for the U.S. Department of Energy under Contract DE-AC05-76RL01830

\title{
Soil Water Balance and Recharge Monitoring at the Hanford Site - FY09 Status Report
}
ML Rockhold
SR Waichler
DL Saunders
RE Clayton
CE Strickland

September 2009

\section{Pacific Northwest}

NATIONAL LABORATORY

Proudly Operated by Battelle Since 1965 


\title{
DISCLAIMER
}

This report was prepared as an account of work sponsored by an agency of the United States Government. Neither the United States Government nor any agency thereof, nor Battelle Memorial Institute, nor any of their employees, makes any warranty, express or implied, or assumes any legal liability or responsibility for the accuracy, completeness, or usefulness of any information, apparatus, product, or process disclosed, or represents that its use would not infringe privately owned rights. Reference herein to any specific commercial product, process, or service by trade name, trademark, manufacturer, or otherwise does not necessarily constitute or imply its endorsement, recommendation, or favoring by the United States Government or any agency thereof, or Battelle Memorial Institute. The views and opinions of authors expressed herein do not necessarily state or reflect those of the United States Government or any agency thereof.

\author{
PACIFIC NORTHWEST NATIONAL LABORATORY \\ operated by \\ BATTELLE \\ for the \\ UNITED STATES DEPARTMENT OF ENERGY \\ under Contract DE-AC05-76RL01830
}

Printed in the United States of America
Available to DOE and DOE contractors from the Office of Scientific and Technical Information,
P.O. Box 62, Oak Ridge, TN 37831-0062;
ph: (865) 576-8401
fax: $(865) 576-5728$
email: reports@adonis.osti.gov

\begin{abstract}
Available to the public from the National Technical Information Service, U.S. Department of Commerce, 5285 Port Royal Rd., Springfield, VA 22161 ph: (800) 553-6847 fax: (703) 605-6900 email: orders@ntis.fedworld.gov

online ordering: http://www.ntis.gov/ordering.htm
\end{abstract}

This document was printed on recycled paper. 


\title{
Soil Water Balance and Recharge Monitoring at the Hanford Site - FY09 Status Report
}

\author{
ML Rockhold \\ SR Waichler \\ DL Saunders \\ RE Clayton \\ CE Strickland
}

September 2009

Prepared for

the U.S. Department of Energy

under Contract DE-AC05-76RL01830

Pacific Northwest National Laboratory

Richland, Washington 99352 



\begin{abstract}
Recharge provides the primary driving force for transporting contaminants from the vadose zone to underlying aquifer systems. Quantification of recharge rates is important for assessing contaminant transport and fate and for evaluating remediation alternatives. This report describes the status of soil water balance and recharge monitoring performed by Pacific Northwest National Laboratory at the Hanford Site for Fiscal Year 2009. Previously reported data for Fiscal Years 2004 - 2008 are updated with data collected in Fiscal Year 2009 and summarized.
\end{abstract}





\section{Summary}

Recharge provides a driving force for transporting contaminants from the vadose zone to underlying aquifer systems. Quantification of recharge rates is therefore important to support calculations of contaminant transport and fate and for design and evaluation of remedial action alternatives. Recharge rates depend on three main factors - soil, vegetation, and climatic conditions - that are highly variable in both space and time. This report reviews the methods that are used for estimating recharge rates and summarizes field soil water balance and recharge data collection efforts for Fiscal Year 2009 at the U.S. Department of Energy's Hanford Site in southeast Washington State. Data for Fiscal Years 2004 through 2009 for various soil and surface covers found and planned in the 200 West and 200 East Areas of the Hanford Site are also presented. In addition, the report provides a summary of weather data collected from the Hanford Meteorological Station from 1957 through 2008. Recharge rates at Hanford are shown to vary from near zero for finer-textured soils (e.g. silt loam) and deeper rooted vegetation (e.g., sagebrush) up to greater than $86 \mathrm{~mm} \mathrm{yr}^{-1}$ for coarse-textured and unvegetated sediments (e.g., gravel-covered surfaces at tank farms). Continued and uninterrupted monitoring is needed to provide long-term continuity of recharge records to assess the variability and uncertainty of recharge rates. 



\section{Acknowledgments}

The work described herein was performed for DOE and CHRPC under the auspices of the Remediation and Closure Science (RACS) project, managed by Mark Freshley (PNNL). We acknowledge Scott Petersen (CHPRC) for continued support and Mark Freshley for project oversight and guidance. We also thank Mike Fayer (PNNL) for his peer review. Portions of this report were taken from Nichols et al. (2008; PNNL-17841) and were updated to include data collected in FY09. 



\section{Acronyms and Abbreviations}

$\begin{array}{ll}\text { bgs } & \text { below ground surface } \\ \text { CHPRC } & \text { CH2M-Hill Plateau Remediation Company } \\ \text { DOE } & \text { U.S. Department of Energy } \\ \text { FHI } & \text { Fluor Hanford, Inc. } \\ \text { FFTF } & \text { Fast Flux Test Facility } \\ \text { FLTF } & \text { Field Lysimeter Test Facility } \\ \text { FY } & \text { Fiscal Year (October 1 to September 30) } \\ \text { HMS } & \text { Hanford Meteorological Station } \\ \text { IDF } & \text { Integrated Disposal Facility } \\ \text { PNNL } & \text { Pacific Northwest National Laboratory } \\ \text { RACS } & \text { Remediation And Closure Science (Project) } \\ \text { RDS } & \text { Remediation Decision Support (Project) } \\ \text { SWL } & \text { solid waste landfill } \\ \text { WFM } & \text { water flux meter }\end{array}$





\section{Contents}

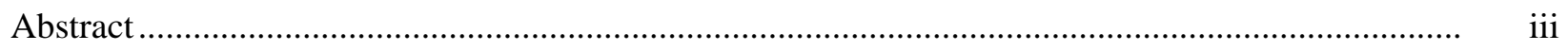

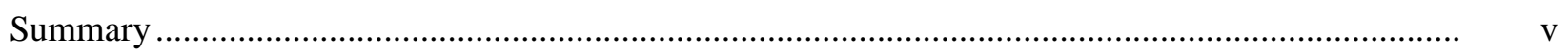

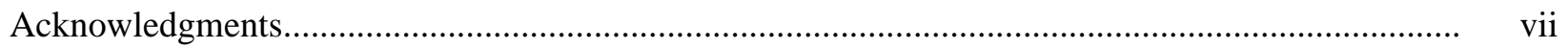

Acronyms and Abbreviations .............................................................................................. ix

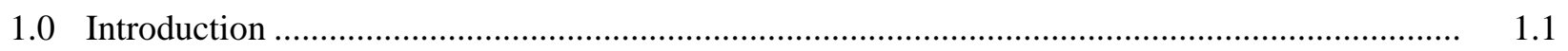

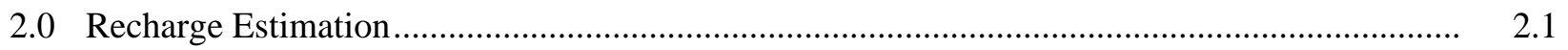

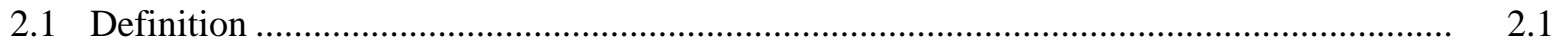

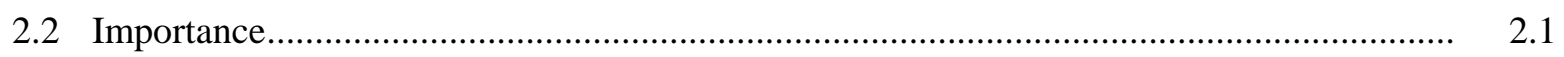

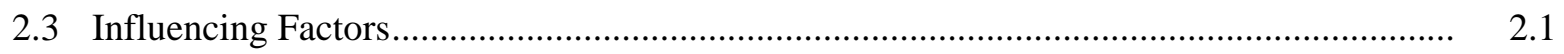

2.4 Estimation Methods.............................................................................................. 2.2

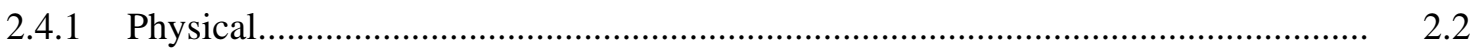

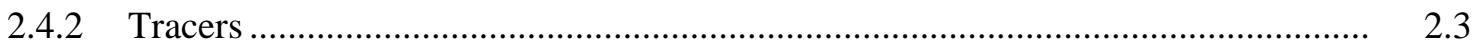

2.4.3 Numerical Modeling ..................................................................................... 2.6

3.0 Brief History of Recharge Investigations at Hanford ........................................................

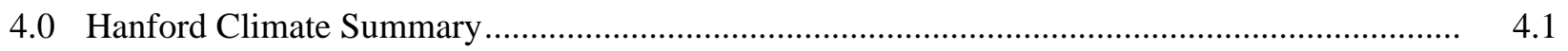

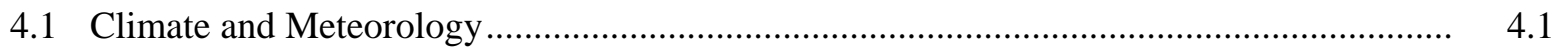

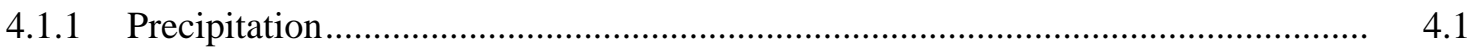

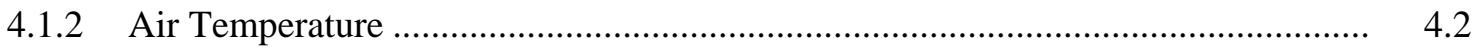

4.1.3 Humidity …............................................................................................ 4.2

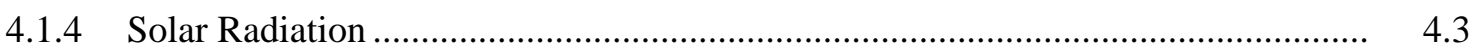

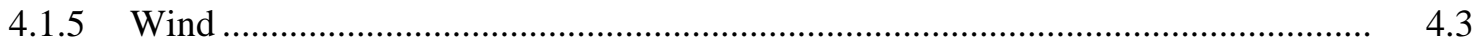

4.2 Long-Term Weather and Climate at HMS .................................................................... 4.3

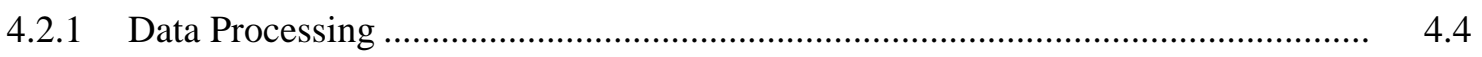

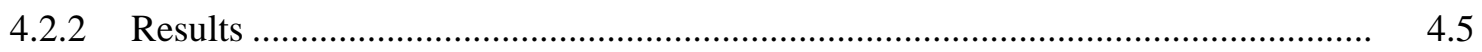

5.0 Recharge Data Collected in FY 2004-2009 ...................................................................... 5.1

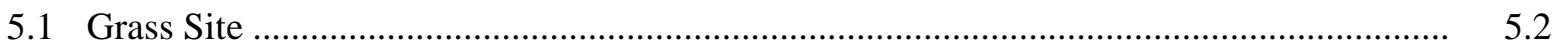

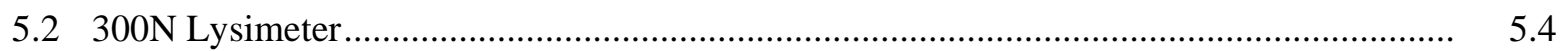

5.3 Solid Waste Landfill (SWL) .................................................................................... 5.10

5.3.1 Vegetation Characterization ....................................................................... 5.13

5.4 Integrated Disposal Facility (IDF) ......................................................................... 5.14

5.5 Field Lysimeter Test Facility (FLTF) ….................................................................... 5.15

5.6 Field Lysimeter Test Facility (FLTF) Pit .................................................................. 5.29

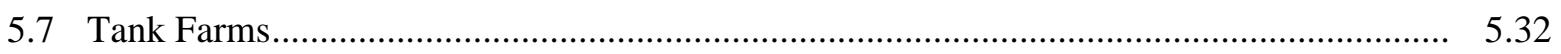

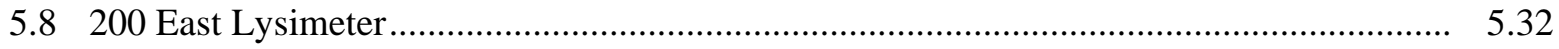

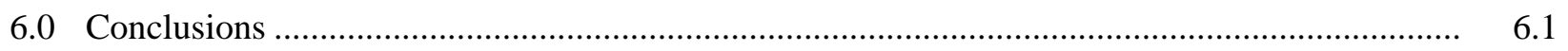

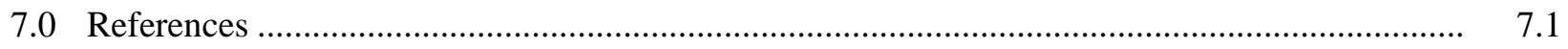




\section{Figures}

2.1 Schematic of Installed Vadose Zone Water Fluxmeter With Diversion Control ....................... 2.4

4.1 Annual Timeseries of HMS Weather Variables and Local Regression Lines .......................... 4.6

4.2 HMS Weather Data Averaged Over Three-Year Periods ....................................................... 4.7

4.3 Windrose Plots Showing Prevalence of Wind Direction at HMS, Based on Counts of Wind Direction in 22.5-Degree Sectors .......................................................................................... 4.8

4.4 Windrose Plots Based on Means of Wind Speed in Each 22.5-Degree Sector for HMS Data ... 4.9

4.5 Monthly Mean Temperature by Year Measured at the HMS, with Loess Lines ...................... 4.10

4.6 Seasonal Loess Applied to Mean Monthly Temperature at the HMS ........................................ 4.11

4.7 Seasonal Loess Applied to Precipitation Measured at the HMS .............................................. 4.12

5.1 Location of Recharge Monitoring Stations at the Hanford Site ............................................ 5.1

5.2 Surface Conditions on the Water Flux Meters at the Grass Site in Autumn 2006 .................... 5.3

5.3 Volumetric Water Content Measured at 30 and $60 \mathrm{~cm}$ Below Ground Surface at the Grass

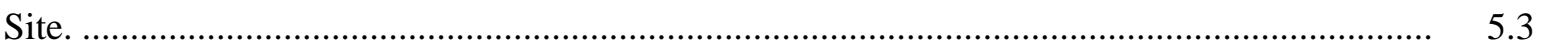

5.4 Cumulative Drainage Measured at the Grass Site Using Water Flux Meters. ........................... 5.4

5.5 Surface Conditions of 300N Lysimeter Site on September 13, 2007...................................... 5.6

5.6 Cumulative Drainage Measured Since 1981 from the South Caisson at the 300N Lysimeter

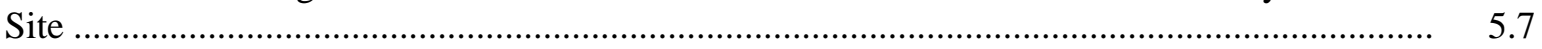

5.7 300N Lysimeter Water Contents Measured at 0.3, 0.6, and 0.9 m Below Ground Surface........ 5.7

$5.8 \quad 300 N$ Lysimeter Matric Potentials Measured at Six Depths. ................................................... 5.8

5.9 300N Lysimeter Cone Penetrometer Tensiometer Matric Potentials Measured Outside of the South Caisson at $7.5 \mathrm{~m}$ Below Ground Surface. ................................................................. 5.9

5.10 WFM Material at the Hanford SWL ............................................................................... 5.10

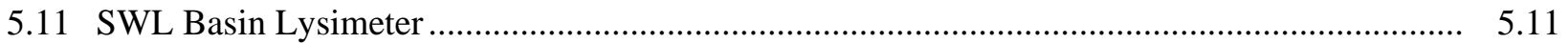

5.12 Volumetric Water Contents Measured at the SWL Site at 30, 60, and $90 \mathrm{~cm}$ Below Ground

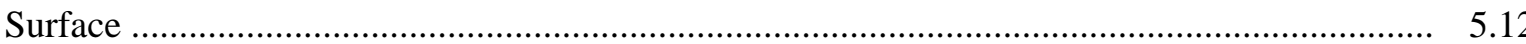

5.13 Cumulative Drainage Measured at the SWL Using Water Flux Meters Since December 21, 2004.

5.14 Cumulative Drainage Measured at the SWL from the Basin Lysimeter Since July 1, 1996. ..... 5.14

5.15 Artist's Rendering of the FLTF at the Hanford Site. ............................................................ 5.16

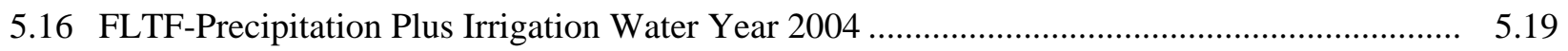

5.17 FLTF Precipitation Plus Irrigation Water Year 2005 ........................................................... 5.19

5.18 FLTF Precipitation Plus Irrigation Water Year 2006........................................................... 5.20

5.19 FLTF Precipitation Plus Irrigation Water Year 2007 ............................................................... 5.20

5.20 FLTF Precipitation Plus Irrigation Water Year 2008........................................................... 5.21

5.21 FLTF Irrigation Plus Precipitation Water Year 2009........................................................ 5.21

5.22 FLTF Cumulative Drainage for FLTF Treatments D5 and D12 Representing a Hanford Barrier Dune Sand Deposition Test. $\mathrm{R}$ is the mean annual drainage rate. 
5.23 Cumulative Drainage for FLTF Treatments D6 and D8 Representing a Sand Dune Migration Test. $\mathrm{R}$ is mean annual drainage rate.

5.24 Cumulative Drainage for FLTF Treatments D2 and D4 Representing a Barrier Side Slope Test. $\mathrm{R}$ is the mean annual drainage rate.

5.25 Cumulative Drainage for FLTF Treatment D13 Representing an Eroded Prototype Hanford Barrier Test. $\mathrm{R}$ is the mean annual drainage rate.

5.26 Cumulative Drainage for FLTF Treatments C1, C2, C4, and C5.

5.27 Changes in water storage for weighing lysimeters W1 and W3 at the FLTF.

5.28 FLTF Matric Potentials for Hanford Barrier Erosion/Dune Sand Deposition Test at $100 \mathrm{~cm}$ Depth.

5.29 FLTF Matric Potentials for Hanford Barrier Erosion/Dune Sand Deposition Test at $150 \mathrm{~cm}$ Depth.

5.30 FLTF Matric Potentials for Sand Dune Migration Test.

5.31 Cumulative Drainage Measured at the FLTF Pit Using Water Flux Meters for Silt Loam, Sand, and Gravel Treatments.

5.32 Cumulative Drainage Measured at the FLTF Pit Using Water Flux Meters for Road Base/Silt Loam, Sand/Silt Loam, and Road Base Treatments.

\section{Tables}

4.1 Monthly Precipitation Variations Between 1947 and 2008 at the Hanford Meteorological Station

4.2 Monthly Air Temperature Variations Between 1945 and 2008 at the Hanford Meteorological Station.

5.1 Monitoring Sites, Activities, and Periods.

5.2 Summary of FLTF Treatments and Monitoring Period

5.3 FLTF Treatment Descriptions

5.4 Summary of FLTF Drainage Rates Though August 20th, 2009

5.5 Chloride Concentrations Measured in FLTF Lysimeter Drainage Waters.

5.6 FLTF Pit WFM Treatments, Monitoring Periods, and Average Drainage Rates. All WFM surfaces in the FLTF pit are unvegetated. 



\subsection{Introduction}

Recharge rates are used as boundary conditions for vadose zone and groundwater flow and transport models used to assess the risk associated with subsurface contamination and the potential effectiveness of remediation alternatives. Recharge is therefore an important quantity to characterize for studies, simulations, and evaluations of waste disposal practices at the Hanford Site. The basis for estimating recharge includes substantial fieldwork and data collection from monitoring sites at Hanford.

Pacific Northwest National Laboratory (PNNL) assembled this report for CH2M-Hill Plateau Remediation Company (CHPRC) as part of the Remediation and Closure Science Project (RACS). The RACS project provides scientific and technical support for waste management and cleanup efforts at the U.S. Department of Energy's (DOE) Hanford Site. The purpose of this report is to update field soil water balance and recharge data, previously reported for monitoring activities in Fiscal Years (FY) 2004 through 2008, with data collected in FY2009.

The most robust estimates of Hanford recharge rates are those that are derived from water balance measurements under Hanford Site soil and climatic conditions. Water balance measurements include direct measurements of drainage and measurements of related variables such as soil water content and soil matric potential. Previously published recharge data packages provide reasonable estimates of site-wide recharge for some soil conditions, but continued monitoring of drainage over a wider range of climate variables (i.e., more extremes in precipitation and temperatures), soil/surface barrier conditions, and over longer time periods serves to refine and improve the defensibility of recharge estimates. For low-drainage conditions, such as those typical of Hanford conditions, these measurements may be required over time scales of decades, or longer, in order to obtain reliable measurements. Significant interruptions in data continuity or site maintenance in these conditions adversely impacts data integrity and thereby reduces the defensibility of recharge estimates derived from those data. This report is produced specifically to document additional data collected in recent years in a citable form, and to use those data to refine recharge estimates.

The scope of this report is limited in the following respects:

- Emphasis is on the 200 East and 200 West Areas of the Hanford Site

- Presents recharge data collected in FY 2004 through FY 2009

This report includes an overview of the parameterization of recharge (Section 2), identification of previously published recharge data (Section 3), presentation of previously published data and new data from FY09 (Section 4), discussion of knowledge gaps (Section 5), and conclusions (Section 6). Portions of this report were taken from Nichols et al. (2008) and updated where appropriate. 
[This page intentionally left blank] 


\subsection{Recharge Estimation}

\subsection{Definition}

Recharge is defined as the flux of water transmitted across the water table from the vadose zone to the saturated zone. Direct measurement of recharge at the water table is usually impractical due to the inaccessibility, especially at Hanford where the water table is commonly located at depths below ground surface (bgs) of 80 meters or more. The influence of aquifer-influencing operations, such as artificial discharges or remediation pump and treat systems, would further complicate efforts at making a direct measurement for a deep water table. Instead, measurements and analyses in the unsaturated zone at shallow depths are used to characterize deep drainage, that is, the water flux leaving the depth below which the processes of evaporation and transpiration can return water from the unsaturated soil to the atmosphere. This deep drainage, with sufficient time, will be manifest as the recharge flux. The time required will depend on the thickness and hydraulic properties of the vadose zone and the deep drainage rate itself. Changes in the deep drainage rate, such as would result from changes in surface vegetative conditions that increase or decrease the evapotranspiration rate, can take many years to be reflected in the recharge rate for a thick vadose zone in arid conditions such as at the Hanford Site and can be an important consideration in characterizing recharge as well (Nichols et al. 2007).

\subsection{Importance}

Recharge is the primary mechanism for transporting contaminants from the vadose zone to groundwater. Bacon and McGrail (2002) demonstrated this by showing the sensitivity of buried immobilized low-activity waste (ILAW) glass release and transport to recharge. Their evaluation of the release of technetium-99 from the ILAW glass for five recharge rates revealed that the technetium-99 flux beneath the ILAW disposal zone is more sensitive to the recharge rate than to any other parameter for recharge rates below $10 \mathrm{~mm} / \mathrm{yr}$. Recharge rates in this range are common for natural vegetation and soil conditions at Hanford. Such a high sensitivity of waste disposal performance to recharge rate underscores the need to characterize this parameter as accurately as possible.

\subsection{Influencing Factors}

Important physical properties and processes that influence recharge include climate, soil hydraulic properties and stratigraphy, vegetative cover, land use, and topography. Climate determines the driving forces for recharge, namely the quantity of precipitation available for the land surface water balance, and the energy fluxes that determine the partitioning of precipitation into evaporation, transpiration, and recharge. Soil hydraulic properties and stratigraphy determine the rate at which water is transmitted through the vadose zone, and hence it's resident time for processes of evaporation and transpiration. Vegetative cover determines the strength of the transpiration portion of the land surface water balance. Land use will change other influencing factors by altering the surface soils and hence the hydraulic properties and soil stratigraphy of a site, and the vegetative cover and hence transpiration rates.

Topography influences the portion of precipitation that is subject to overland flow, either "run-on" or "run-off", for a given site. Knowledge of all of these influences is important to the estimation of recharge at a given location. 


\subsection{Estimation Methods}

Recharge rates at the Hanford Site can range from near zero to more than $100 \mathrm{~mm} / \mathrm{yr}$ (Gee et al. 1992). Measuring a parameter that varies over such a large range requires use of complementary methods. An excellent overview of recharge estimation techniques is provided in Scanlon et al. (2002). The methods in use at the Hanford Site include physical techniques (water balance, lysimetry), tracer techniques (chloride, isotopes), and numerical techniques (computer simulation). These are other methods are discussed at length relative to arid climates such as that at Hanford in the January-February 1994 issue of the Soil Science Society of American Journal, which contains a series of papers that were presented at a symposium titled "Recharge in Arid and Semiarid Regions." A brief overview of each technique in use at the Hanford Site is provided here for reference purposes.

\subsubsection{Physical}

Physical methods attempt to calculate recharge as a residual after measuring other terms (precipitation, evaporation, transpiration, runoff, storage) in the land surface water budget (water balance technique) or directly measure recharge in using an apparatus (lysimeter, water flux meters).

\subsubsection{Water balance}

Water balance methods rely on measurement of several terms in the land surface water balance equation to derive recharge as a residual:

$$
D=P-E T-R+\Delta S
$$

where $D$ is drainage (taken to represent recharge) calculated as total precipitation $(P)$ less water returned to the atmosphere through evapotranspiration (ET), less water that runs on or off the control surface $(R)$, plus the net change in storage of water in the soil zone to the depth that evapotranspiration processes affect $(\Delta S)$. Precipitation is easily and directly measured. Runoff is often not a parameter of importance for the soils of concern at Hanford, except perhaps along the western edge of the Hanford Site near Rattlesnake Mountain. Soil moisture must be measured over the depth range that is affected by evapotranspiration and at frequent time intervals to complete the calculation of recharge (drainage) as a residual.

\subsubsection{Lysimetry}

A lysimeter is an in situ recharge measurement system that can be used to collect water that has flowed through and below the reach of the evaporation process and plant roots to become deep drainage, and eventually, recharge. The objective of lysimetry is to collect both performance data and model testing data for specific combinations of soil, vegetation, and precipitation. Lysimetry is one of only two methods available (the other being drainage flux meters) to directly measure deep drainage and thereby recharge. A lysimeters primary strength is that it can provide a control volume in which a number of water balance components can be integrated and measured directly. This control volume provides the data necessary to calibrate numerical models, that can in turn be used to predict recharge. 
While lysimeters provide a direct measure of recharge, they possess some disadvantages. Lysimeters are usually fixed in space, limiting their ability to quantify the effects of spatial variability. The soil filling the lysimeter may not represent the natural stratification or layering that may be present. The length of a lysimeter record is usually much shorter than time periods of interest, although the longer the lysimeter is operated the more this drawback is alleviated. The lysimeter walls and base alter the natural gradients of temperature, air flow, and vapor flow that could be of importance in measuring recharge rates less than $1 \mathrm{~mm} / \mathrm{yr}$. Lysimeter walls restrict lateral root growth and artificially promote downward growth. When an irrigation treatment is used, lysimeter tests are subject to an "oasis effect," a scale effect where heat from un-irrigated surroundings increases the evapotranspiration rate above what it would have been if the entire area surrounding the lysimeter been irrigated. Finally, it is critical to verify that no leaks of drainage water occur in the lysimeter before the data collected are used.

Lysimeters have long been used at the Hanford Site for several purposes (Hsieh et al. 1973, Gee and Jones 1985, Freeman and Gee 1989, Wittreich and Wilson 1991, Gee et al. 1993, Ward et al. 1997). Lysimeters used to provide data reported in this compendium include containers that isolate the soil from its surroundings and field-scale pads that collect drainage but do not isolate the soil.

\subsubsection{Water Flux Meters (WFMs)}

The function and design of a vadose zone water flux meter (WFM) for direct, in situ measurement of recharge is described in Gee et al. (2002). The design, illustrated in Gee et al. (2002) and shown here as Figure 2.1, concentrates flow into a narrow sensing region filled with a fiberglass wick. The wick applies suction, proportional to its length, and passively drains the meter. Such a meter can be installed in an augured borehole at almost any depth below the root zone. Water flux through the meter is measured with a self-calibrating tipping bucket. Further enhancement to this design are discussed in Gee et al. (2003b).

\subsubsection{Tracers}

Tracer methods estimate past recharge by means of measuring the vertical distribution of a tracer in soil and sediments of the vadose zone. Several tracers are available that enable estimates of recharge rates: the ones used at Hanford have included chloride and chlorine-36 (Fayer et al. 1999, Fayer and Szecsody 2004) and the stable isotopes deuterium and oxygen-18 (DePaolo et al. 2004, Fayer and Szecsody 2004, Singleton et al. 2006).

\subsubsection{Chloride and Chloride-36}

Chloride originates from seawater, is deposited naturally, and can provide recharge estimates spanning hundreds to thousands of years. In contrast, the isotope chlorine-36 originates from two sources: cosmic irradiation of atmospheric chloride and surface and atmospheric nuclear weapons testing. The quantities of chlorine-36 created through nuclear weapons testing far exceeds natural production rates from cosmic irradiation and therefore furnishes a distinctive marker in the subsurface environment, particularly for arid regions with low recharge rates where this "bomb pulse" is still in transit through the vadose zone. Chlorine-36 data is used to estimate the average recharge rate over the last 50 years for such environments. 


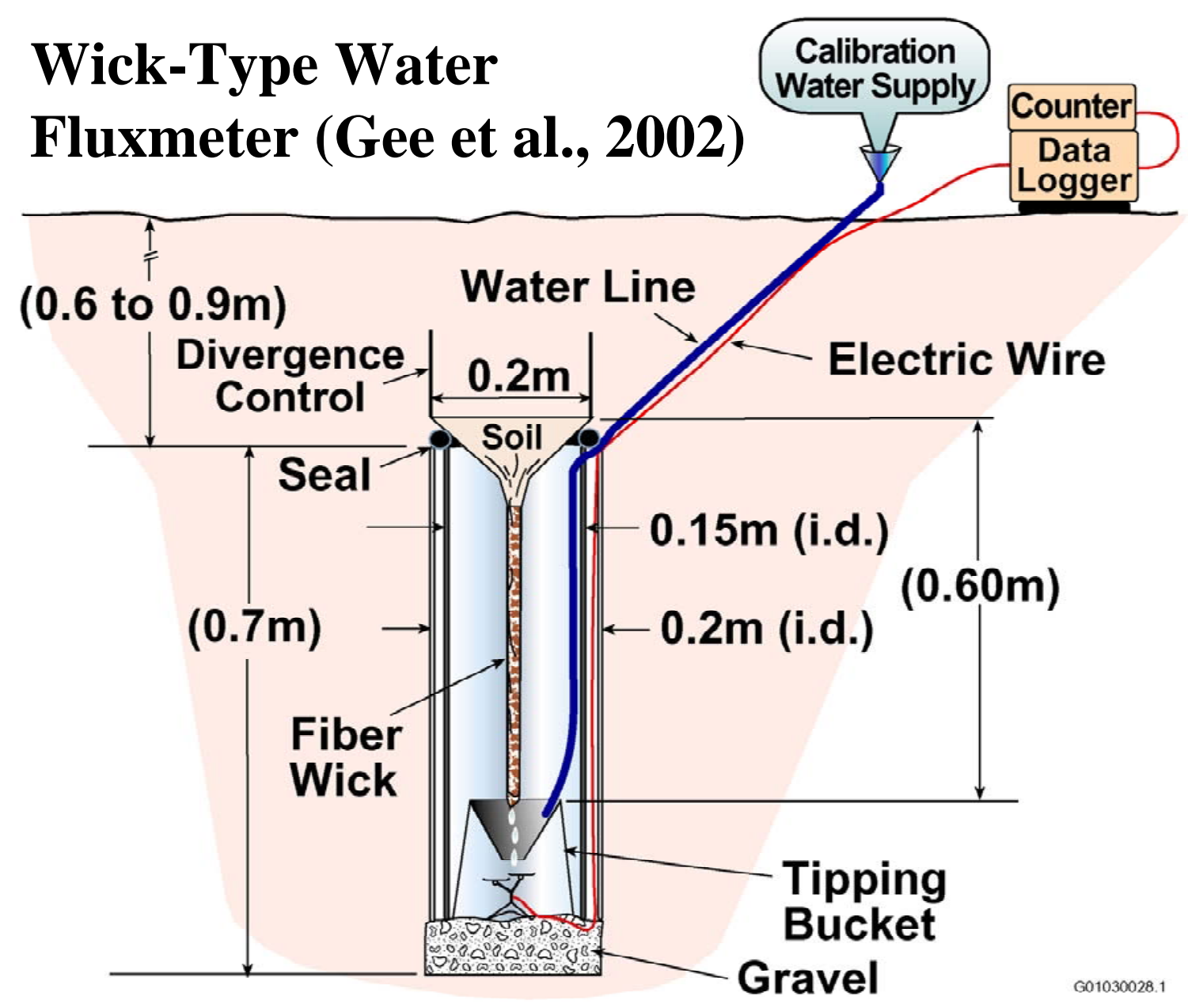

Figure 2.1. Schematic of Installed Vadose Zone Water Fluxmeter With Diversion Control (Gee et al. 2002)

Both chloride and chlorine-36 are conservative, nonvolatile, and almost completely retained in the soil when water evaporates or is transpired by plants (Phillips 1994). Some chloride is subject to plant uptake; examples of this shown in Rickard and Vaughn (1988) and in Sheppard et al. (1998). Over hundreds to thousands of years, plant cycling is expected to have a minimal impact on the evolution of the chloride distribution in the soil profile beneath plants. Recharge rates determined using chloride as a tracer reflect conditions that existed hundreds to thousands of years ago and are sometimes called paleorecharge or paleofluxes. When using such paleofluxes to represent current or future conditions, the assumption is that the climate, soil, and vegetation conditions remain similar. In contrast, bomb-pulse chlorine-36 has been present in the environment for only about 50 years. In soils with high $\mathrm{pH}$ and high adsorption of other anions, anion exclusion can result in faster movement of chloride. Previous studies strongly suggest a relationship between soil surface area, which is primarily determined by clay content, and anion exclusion, for example Thomas and Swoboda (1970). Most of the sandy soil found at the Hanford Site has a relatively low percentage of clay, so the effects of anion exclusion in this soil would be relatively minor. Two other issues that affect chloride-based estimates of recharge are mineral dissolution and the chloride dilution that is part of the measurement technique. Both issues can be significant when recharge rates exceed a few millimeters per year (Tyler et al. 1999). 
Phillips (1994) suggested that systematic uncertainties in estimated chloride deposition rates can be as great as $20 \%$ if the chloride mass balance technique is extended to estimate recharge rates prior to the Holocene epoch (approximately 10,000 years ago). Scanlon (2000) suggested the uncertainty was as high as $38 \%$. Because the Hanford Site was flooded by glacial melt water about 13,000 years ago, the interpretation is not extended beyond that time. Therefore, the uncertainty in chloride deposition rates at the Hanford Site is expected to be less than $38 \%$.

There is some uncertainty about the local influence that Hanford Site operations may have had on the time-dependent concentrations of both chloride and chlorine-36 deposited at Hanford (Fayer et al. 1999). Murphy et al. (1991) examined the issue relative to chlorine-36 and concluded there was no nearby source that would confuse the chlorine-36 signal in the sediment.

\subsubsection{Deuterium and Oxygen-18}

Deuterium and oxygen-18 are inert isotopes of hydrogen and oxygen, respectively, that are naturally occurring. Their concentration increases as the lighter components evaporate disproportionately. The increased concentration can be used to delineate seasonal variations in water flux, identify the depth of evaporative enrichment, and roughly estimate recharge.

The recharge rate is determined largely by the magnitude of transpiration and evaporation relative to precipitation and overland flow that has infiltrated the soil. Because water consists of several isotopes of hydrogen and oxygen, each with slightly different atomic weights, evaporation tends to remove the lighter isotopes preferentially. The net result is that the residual water contains a higher proportion of the heavier isotopes. There is a progressive decrease in the proportion of heavy stable isotopes with soil depth because evaporation decreases with depth and because of mixing with infiltrating water. At some depth, the isotopic profile becomes somewhat uniform; this depth represents the vertical extent of significant water vapor flux. The amount of enrichment (relative to the isotopic signature in precipitation) is indicative of the recharge rate.

Oxygen-18 and deuterium are the two isotopes that constitute useful tracers because they are stable (and benign) and occur in measurable quantities. The oxygen-18 and deuterium ratios $\left(R={ }^{18} \mathrm{O} /{ }^{16} \mathrm{O}\right.$; $\left.R={ }^{2} \mathrm{H} /{ }^{1} \mathrm{H}\right)$ are used to express isotopic composition in delta $(\delta)$ units relative to a standard material as follows:

$$
\delta=\left[\frac{R_{\text {sample }}}{R_{\text {stan dard }}}-1\right] \times 1000
$$

where $\delta$ is reported in permil units (\%o; a $\delta$ value of $10 \%$ is equivalent to $1 \%$ ). Typical values for winter precipitation (the primary source of recharge water for the climate at the Hanford Site) are -19 to -16\%o for $\delta{ }^{18} \mathrm{O}$ and -142 to $-120 \%$ for $\delta{ }^{2} \mathrm{H}$ (Singleton et al. 2006). The actual depth of enrichment will depend on factors that include recharge rate, soil properties, meteorological conditions, and average annual temperature. Murphy et al. (1991) described how deuterium and oxygen-18 could be used to understand recharge rates at the Hanford Site. 


\subsubsection{Numerical Modeling}

Numerical modeling of unsaturated flow in the vadose zone can be used to estimate recharge rates, but because this method introduces the highest uncertainty it is usually reserved for situations where there are little or no data, or to leverage limited short-term data to estimate long-term recharge.

Simulations of recharge at Hanford have been successful at highlighting the important factors that affect recharge and predicting recharge rates for specific cases. Modeling is the primary tool for forecasting recharge rates for future climate and land use scenarios. The simulations also allow the results of the lysimetry and tracer methods to be merged on a consistent basis. 


\subsection{Brief History of Recharge Investigations at Hanford}

Recharge at the Hanford Site has been studied for decades because of its importance to evaluation of waste transport in the vadose zone and unconfined aquifer. Examples of early attention to natural recharge included the studies of the 200 East Area deep well by Enfield and Hsieh (1971) and Enfield et al. (1973).

With the transition of the Hanford Site's mission from nuclear materials production to environmental cleanup, more resources and effort were brought to bear on measuring and estimating natural recharge at the site. A lysimeter facility was constructed, maintained, and monitored to measure recharge rates for several soil and vegetation covers (Gee 1987, Gee et al. 1989). The 200 East Lysimeter was also constructed and data collection began there (Routson et al. 1988, Gee et al. 1994) and later a lysimeter was installed north of the 300 Area (Gee et al. 2005).

In the mid-1990s a site-wide map of natural groundwater recharge was constructed by using numerical simulation along with soil and vegetation cover maps to extrapolate available point measurements (Fayer and Walters 1995). Site-specific recharge measurements for areas of special interest were undertaken such as at the prototype Hanford Barrier to measure the effectiveness of proposed infiltration barriers (Ward et al. 2005). Data packages were prepared to support compliance assessments including the Solid Waste Landfill (SWL) (Gee et al. 2005), the Integrated Disposal Facility (IDF) (Rockhold et al. 1995, Fayer et al. 1999, Fayer and Szecsody 2004) and the recharge data package for the RCRA Facility Investigation (Fayer and Keller 2007).

By the late 1990s tracer-based methods began to be employed in addition to water balance measurement based methods to estimate recharge (Murphy et al. 1996, Prych 1998, Fayer et al. 1999, Maher et al. 2003, DePaolo et al. 2004, Fayer and Szecsody 2004, Gee et al. 2005, Maher et al. 2006, Singleton et al. 2006, Keller et al. 2007).

Monitoring of field soil water balance and recharge measurement sites has continued at a low level for the past several years. In the following sections a summary of the climate at Hanford is given, followed by a presentation of water balance and recharge data collected at various field sites from 2004-2009. 
[This page intentionally left blank] 


\subsection{Hanford Climate Summary}

\subsection{Climate and Meteorology}

The Cascade Mountains, $100 \mathrm{~km}$ to the west, exert a strong rain-shadow effect on the climate of the Hanford area. This mountain range also serves as a source of cold air drainage, which has a considerable effect on the wind regime on the Hanford Site. Climatological data have been collected at the Hanford Meteorological Station (HMS) since 1945 (Hoitink et al. 2005). HMS is the primary weather station on the Hanford Site and is sited between the 200 East and 200 West Areas at $733 \mathrm{ft}(223 \mathrm{~m})$ elevation, latitude 46.563, longitude 119.599. The data are representative of the general climatic conditions for the region and describe the specific climate of the Central Plateau.

Most of the statistics presented in sections 4.1.1-4.1.5 (through "Wind") are gleaned from tables provided on the HMS website. These tables are updated versions (through 2008) of those presented in the last available annual summary report, for the year 2004 (Hoitink et al. 2005). Other statistics in these sections come directly from Hoitink et al. (2005) and are cited as such; these have not been updated but are believed to still be valid.

\subsubsection{Precipitation}

Between 1947 and 2008, annual precipitation at the HMS averaged $172 \mathrm{~mm}$ and varied between 76 and $313 \mathrm{~mm}$. Table 4.1 shows how monthly averages have varied in that time. The wettest season on record was the winter period from December 1996 to February 1997, with $138 \mathrm{~mm}$ of precipitation; the driest season was the summer of 1973 (June-August) when only $0.8 \mathrm{~mm}$ of precipitation was measured.

On average, half of the annual precipitation occurs during the four months from November through February. A rainfall intensity of $20 \mathrm{~mm} / \mathrm{hr}$ persisting for 1 hour is expected only once every 1,000 years (Hoitink et al 2005). A day with $18 \mathrm{~mm}$ precipitation is expected to occur about once every 2 years, while a day with $54 \mathrm{~mm}$ precipitation is expected only once every 1,000 years. Hanford nearly experienced such a 1,000-yr event when it received $48.5 \mathrm{~mm}$ in a 24-hr period in October 1957.

Snowfall accounts for about $42 \%$ of all precipitation from November through February. Monthly average snowfall is greatest in December $(126 \mathrm{~mm})$ and January $(132 \mathrm{~mm})$. The record monthly snowfall of $594 \mathrm{~mm}$ occurred in January 1950. The seasonal record snowfall of 1,425 mm occurred during the winter of 1992-1993. This amount has a return period of almost 500 years. On average, the first measurable snow appears on November 29 and the last on February 16. Since 1946, snow has been measured as early as October 22 and as late as May 24.

Total precipitation measured at the HMS from September 2008 through August 2009 was $133.9 \mathrm{~mm}$. For September 2007 through August 2008 the total precipitation measured at HMS was 151.9 mm, and for September 2006 through August 2007 it was $164.2 \mathrm{~mm}$. Therefore the total precipitation in FY09 and in the preceding two years was somewhat lower than the long-term average of $172.3 \mathrm{~mm}$ (Table. 4.1). 
Table 4.1. Monthly Precipitation (mm) Variations Between 1947 and 2008 at the Hanford Meteorological Station

\begin{tabular}{lccc}
\hline Month & Maximum & Mean & Minimum \\
\hline January & 62.7 & 23.9 & 2 \\
February & 53.3 & 16.1 & 0 \\
March & 47.2 & 12.5 & 0.5 \\
April & 56.6 & 12 & 0 \\
May & 51.6 & 13.1 & 0 \\
June & 74.2 & 13.5 & 0 \\
July & 44.7 & 5.1 & 0 \\
August & 34.5 & 6.2 & 0 \\
September & 34 & 7.7 & 0 \\
October & 69.1 & 13.3 & 0 \\
November & 67.8 & 22.4 & 0 \\
December & 93.7 & 26.5 & 1.8 \\
Annual & 312.7 & 172.3 & 75.9 \\
\hline
\end{tabular}

\subsubsection{Air Temperature}

Table 4.2 shows the range of monthly temperatures since 1945 . The highest winter monthly average temperature was $7.0^{\circ} \mathrm{C}$ in February 1958 and 1991, while the lowest average temperature was $-11.1^{\circ} \mathrm{C}$ in January 1950 . The highest summer monthly average temperature was $27.9^{\circ} \mathrm{C}$ in July 1985 , while the lowest average temperature was $17.2^{\circ} \mathrm{C}$ in June 1953.

During 1955-2008, there were, on average, 49 days during the months of April through September with maximum temperatures $\geq 32^{\circ} \mathrm{C}$ and 12 days with maxima $\geq 38^{\circ} \mathrm{C}$.

During the months of October through March, an average of 84 days had temperature minimums below $0^{\circ} \mathrm{C}$; an average of 2 days had minimum temperatures that were $\leq 18^{\circ} \mathrm{C}$.

During 1945-2008, the record maximum temperature is $45^{\circ} \mathrm{C}$; the record minimum temperature is $31^{\circ} \mathrm{C}$. The potential for plant activity can be represented by the number of growing days, which is the number of days between the last freezing temperature in spring and the first freezing temperature in autumn. During 1945-2004, the number of growing days averaged 181 days per year, with annual values ranging from 142 (in 1974) and 216 days (in 1994) (Hoitink et al. 2005).

\subsubsection{Humidity}

Since 1955, the average annual relative humidity at the HMS has been 55\%; annual values ranged from 49 to 59\%. December had the highest monthly average humidity (81\%), with values that ranged from 70 to $90 \%$. July had the lowest monthly average humidity (33\%), with values that ranged from 22 to $46 \%$. 
Table 4.2. Monthly Air Temperature (C) Variations Between 1945 and 2008 at the Hanford Meteorological Station

\begin{tabular}{lccc}
\hline Month & Maximum & Mean & Minimum \\
\hline January & 5.8 & -0.5 & -11.1 \\
February & 7 & 3.2 & -3.6 \\
March & 10.8 & 7.5 & 4.1 \\
April & 14.6 & 11.6 & 8.6 \\
May & 20.4 & 16.6 & 13.3 \\
June & 24.9 & 20.8 & 17.2 \\
July & 27.9 & 24.9 & 21.4 \\
August & 27.5 & 24 & 21 \\
September & 22.5 & 19 & 14.9 \\
October & 15.3 & 11.7 & 8.8 \\
November & 8.1 & 4.5 & -4 \\
December & 3.6 & 0.1 & -6.1 \\
Annual & 13.6 & 11.9 & 9.8 \\
\hline
\end{tabular}

\subsubsection{Solar Radiation}

Since 1955, the average annual daily solar radiation at the HMS has been 351 langleys. Average daily values were lowest in December (81 langleys) and highest in July (627 langleys). Five dates have no recorded solar radiation; the lowest non-zero observed daily value was 6 langleys on December 11, 2002; the highest observed daily value was 861 langleys on June 8, 1977.

\subsubsection{Wind}

Prevailing wind directions on the Central Plateau were either from the west-northwest or northwest in all months of the year. At a height of $15.2 \mathrm{~m}$ (50 ft), average annual (1945-2004) wind speed was $12.2 \mathrm{~km} / \mathrm{hr}$ (Hoitink et al. 2005). Monthly average wind speeds were lowest during the winter months $(9.7 \mathrm{~km} / \mathrm{h}$ in December) and highest during the summer (14.6 km/hr in June). Peak wind gusts in every month originated from the west-southwest, southwest, and south-southwest; monthly peak gusts varied from 105 to $129 \mathrm{~km} / \mathrm{hr}$.

\subsection{Long-Term Weather and Climate at HMS}

The amount and timing of natural recharge depends on the interaction of weather, vegetation, and soil. Climate change is potentially significant for recharge, so for this year's report, weather data at the Hanford Meteorological Station (HMS) were analyzed for long-term trends. Hourly data from 1/1/1955 to 12/31/2008 (54 years; 473,376 hourly records) were provided by Ken Burk/PNNL. The weather variables most relevant for hydrology and used for this analysis were: air temperature, dew point temperature, precipitation, snow fall, snow water equivalent, wind speed, wind direction, sky cover, and solar radiation.

HMS staff used to publish annual summary reports on weather and climate at Hanford, ending with year 2004 (Hoitink et al. 2005). These reports emphasized statistics of normal and extreme weather and compared the current year to a 30-year period. Hoitink et al. did not attempt to characterize longterm trends. 


\subsubsection{Data Processing}

First, the raw data text files were joined together into a single, $32 \mathrm{MB}$ file. A text editor was used to change obvious "not available" values in the entirely numeric file, e.g. 999 for air temperature, to "NA". Next, the revised file was read into the R software environment (version 2.9.1, R Team, 2009), where all subsequent processing and graphing took place, using a multi-part script. Erroneous (out-of-order) date and time values were fixed, and records having hour $=24$ (midnight) were changed to hour $=0$ on the next day. For each variable, complete information about missing values was generated, including the number of time gaps and the beginning and ending time of each gap. Most variables had very few missing values, ranging from 0 to $0.93 \%$ of the total record. The two major exceptions to this were wind direction, missing 6\% of records, primarily during 1971-1973; and sky cover, missing 6\%, primarily during 19721973 and weekend nights after April 1995. Sky cover requires a human observer and staffing was reduced in 1995.

Since trends in climate rather than short-term weather variations were of interest, the hourly values were aggregated to daily, monthly, and annual timeseries, and saved to plain text files. Aggregation consisted of taking the mean of the hourly data for the respective time period, except as noted in the additional comments about individual variables below.

Daily mean, minimum, and maximum temperatures were generated from the hourly data. Monthly and annual values are means of the daily values. Units are degrees $\mathrm{F}$.

Dew point temperature is a measure of absolute humidity, a factor in evapotranspiration from the land surface. Units are degrees F.

Rainfall and snow water equivalent were recorded in number of hundredths of inches (0.01"), with $50=$ Trace. Rain is the liquid component of hourly precipitation, and snow water equivalent (SWE) is the liquid equivalent of frozen hourly precipitation. Rain and SWE were added together to obtain total hourly precipitation. Aggregation to daily, monthly, and annual timesteps was done by summing the hourly values with Trace amounts assigned a value of zero. Precipitation was converted to mm, and snow fall was converted to $\mathrm{cm}$.

Snow fall was recorded in number of tenths of inches (0.1”), respectively, with $50=$ Trace. Snow fall is the depth of frozen precipitation that falls during the hour.

Wind speed was recorded in miles per hour. Wind direction was recorded as one of 16 compass sectors before 1986, with $1=$ NNE (center value $22.5 \mathrm{deg}$ ), $2=\mathrm{NE}$ (center value $45 \mathrm{deg}$ ), 16 = north (center value 0 deg), etc. From 1986 on, the values range from 1 to 36 and are the compass direction divided by 10 . For all times, $0=$ calm. Wind direction values not falling in these ranges were assigned NA. All valid data were converted to compass direction (0 to $360 \mathrm{deg}$ ).

Sky cover is the fraction of the celestial dome that is obscured by clouds or fog, recorded in tenths. All values greater than 10 were assigned NA, and the valid data was converted to percent.

Solar radiation was recorded in langleys per minute $(1 \mathrm{gm}-\mathrm{cal} / \mathrm{cm} 2 / \mathrm{min})$. Negative solar data were assigned NA. Daily solar radiation was computed by multiplying the hourly values by 60 and summing them. Monthly and annual values were means of the daily values. 


\subsubsection{Results}

The simplest way to consider long-term trends is to look at a plot of annual timeseries (Figure 4.3). The data are plotted with robust, locally-weighted polynomial regression ("loess") lines that represent the trend. The three air temperature variables have similar patterns, with the average trend varying up to 2.5 degrees over the period of record. Hanford has been in an overall cooling trend since the early 1990s. Precipitation is highly variable in the steppe climate, with a coefficient of variation $(\mathrm{CV})=29 \%$, but a significant long-term trend is not apparent. Annual snow fall and snow water equivalent are even more variable (CV 72\%), and again no significant long-term trends are evident. Average annual wind speed has fluctuated up to a couple miles per hour in a similar pattern to air temperature. Average sky cover has declined from $58 \%$ to $51 \%$ over the last 30 years, but solar radiation has not changed appreciably over the same time period.

Since year-to-year variability in weather variables can be large, it is also instructive to consider averages over discrete multi-year time periods. Figure 4.4 shows climate averaged over three-year periods. There is considerable variation between three-year periods, indicating that recharge would also be highly variable even at this multi-year timescale. For example, average annual precipitation was 258 mm during 1994-96, but only $165 \mathrm{~mm}$ during the most recent period. Since the 1994-96 period there seems to be a clearer inverse relationship between sky cover and solar radiation than was indicated in the loess smoothing of the annual timeseries. Figures 4.5 and 4.6 show windrose counts and means, respectively, for six-year periods. The same pattern of wind has held over time-winds are predominantly from the west to northwest, but many of the strongest winds come from the southwest.

Variability from year to year for a given month is also large, as shown in Figure 4.6, which shows mean temperature by month across years. Loess lines are again shown in an attempt to characterize trends. Some are intriguing, such as the rise in March over the first 30 years of record, but the scatter of the data is such that the apparent trends are relatively uncertain.

Finally, another way to evaluate long-term trend is to formally separate a timeseries into seasonal, trend, and remainder components using an iterative loess procedure (Cleveland et al. 1990). The decomposition for mean temperature is shown in Figure 4.7. The procedure is as follows. The seasonal (monthly) component is found by taking the mean for each month across all years. Then the monthly component is removed from the data, and the remainder is smoothed with loess to find the long-term component, which includes trends and oscillations whose periods are longer than monthly. Then that long-term component is subtracted from the data, and a new seasonal component is smoothed to the remainder. Then the new seasonal component is again subtracted from the data and a new long-term component is fit to the remainder, and so on. The final result is an additive model: Data = Monthly + Trend + Remainder. The remainder term is the residual from the combined monthly and trend terms. The monthly term can also be fit by loess instead of taking the means, but the mean approach was used here to emphasize variability in the long-term component. 
Annual Time Series
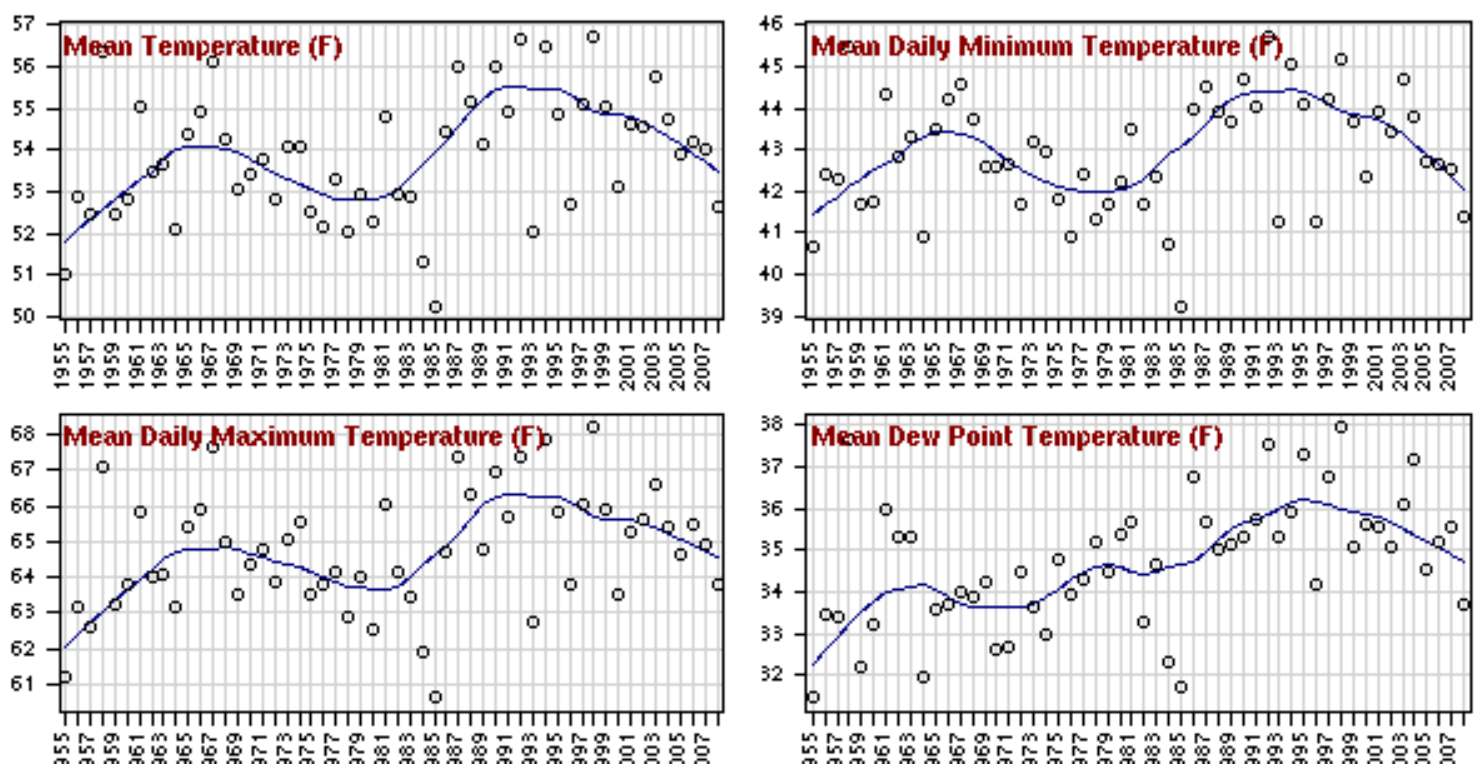

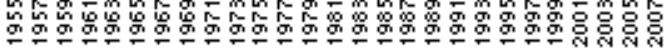

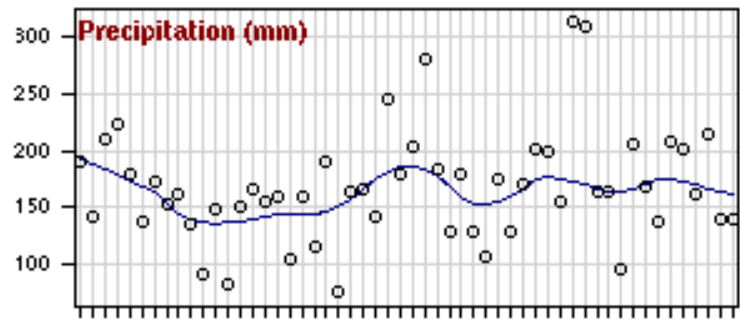

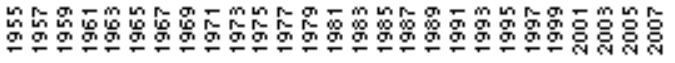
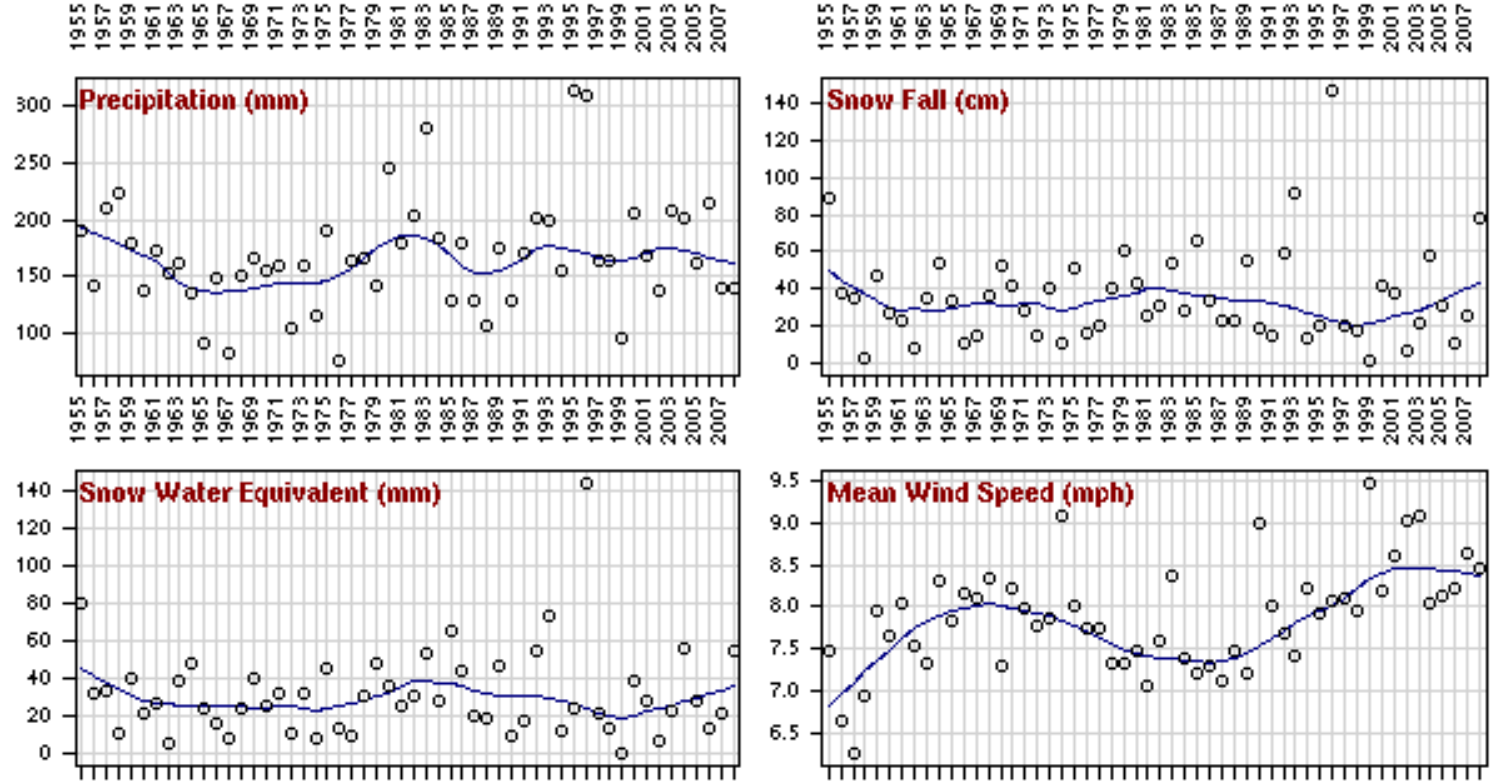

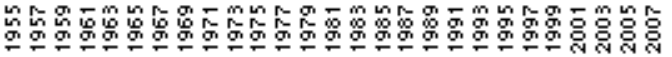
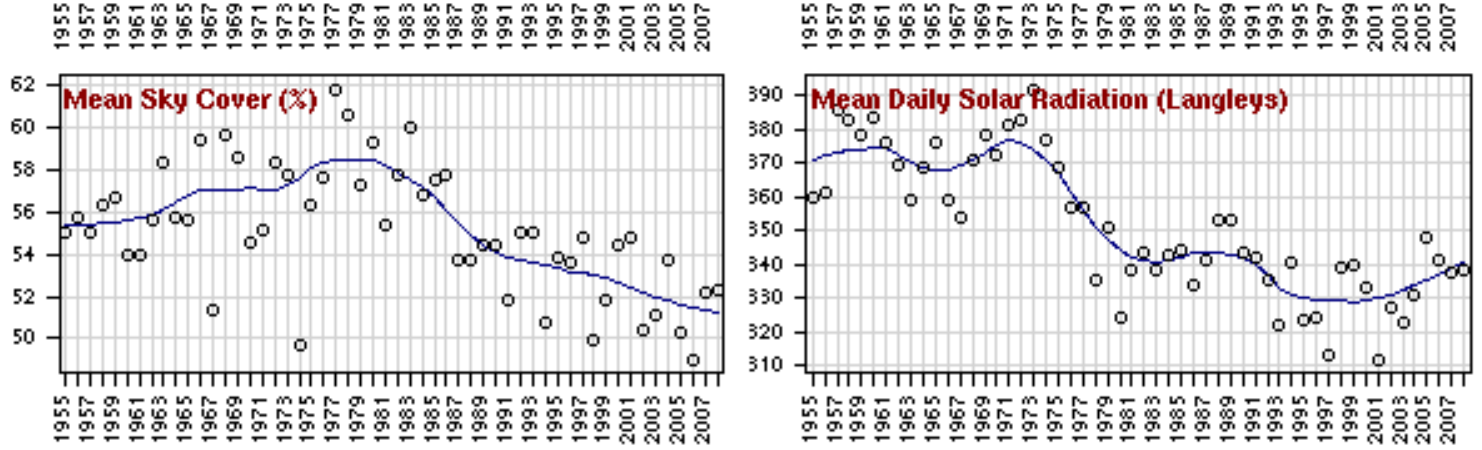

Figure 4.1. Annual Timeseries of HMS Weather Variables and Local Regression (Loess) Lines 


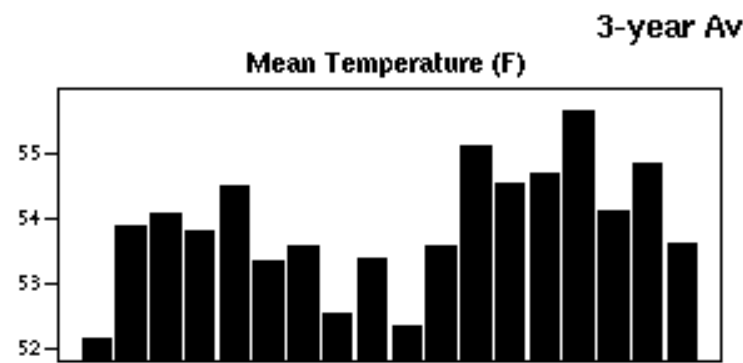

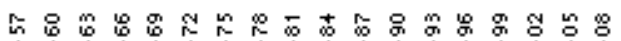

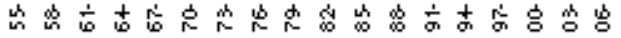
Mean Daily Maximum Temperature (F)

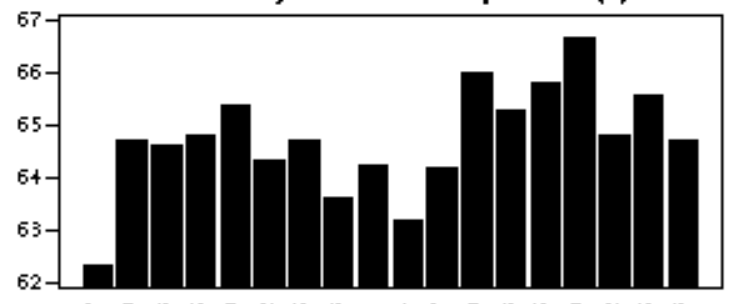

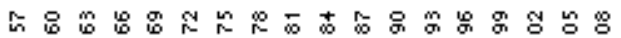

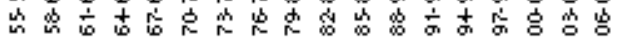
Precipitation ( $\mathrm{mm}$ )

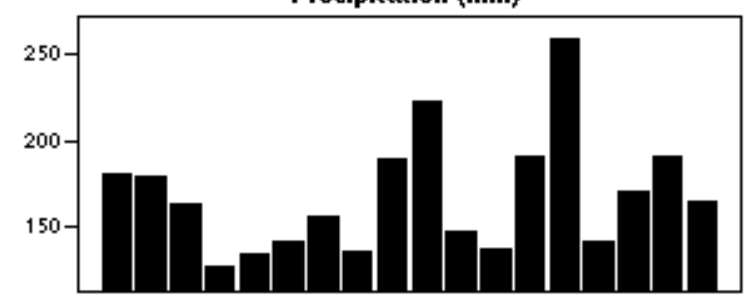

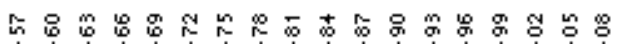

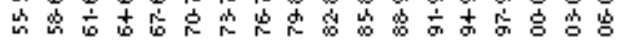
Snow Water Equivalent (mm)

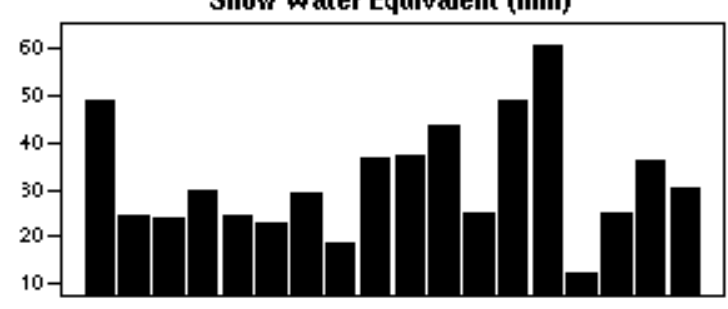

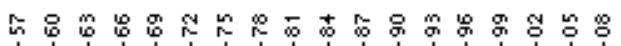

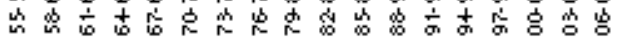
Mean Sky Cover $(\%)$

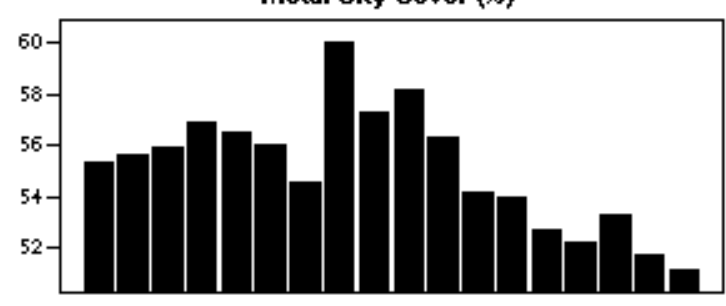

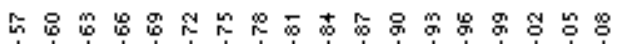

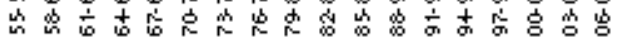

Mean Daily Minimum Temperature (F)

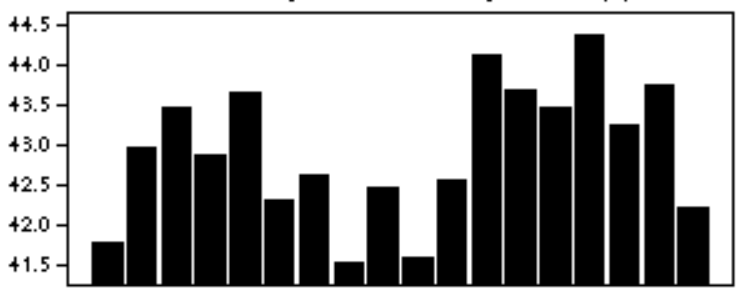

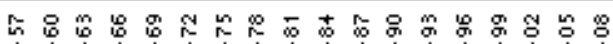

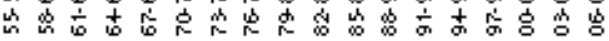
Mean Dew Point Temperature (F)

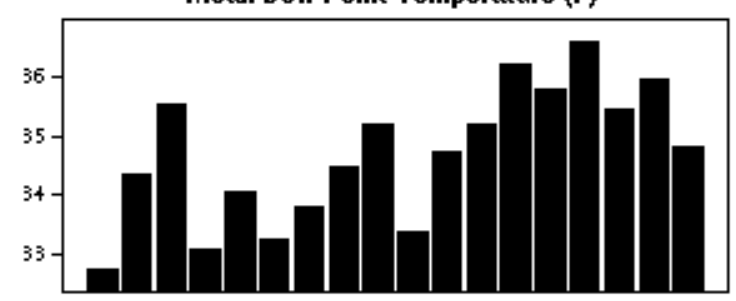

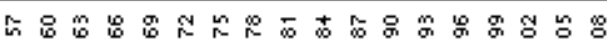

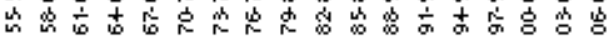
Snow Fall (cm)

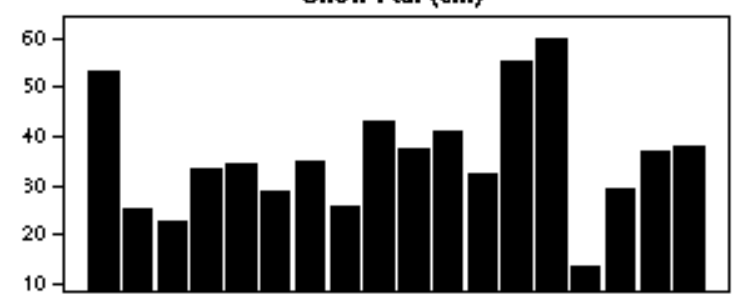

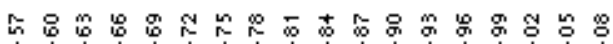

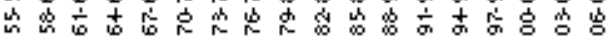
Mean Wind Speed (mph)

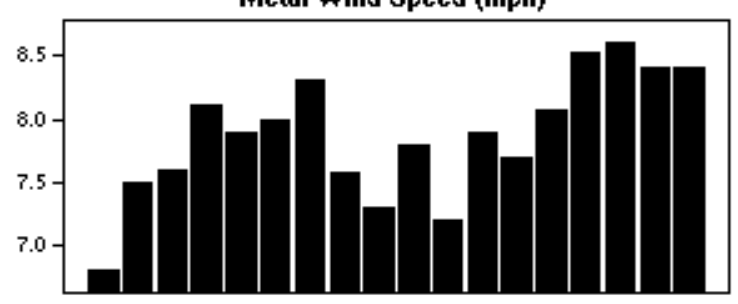

几

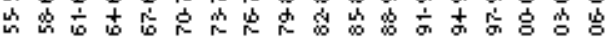
Mean Daily Solar Radiation (Langleys)

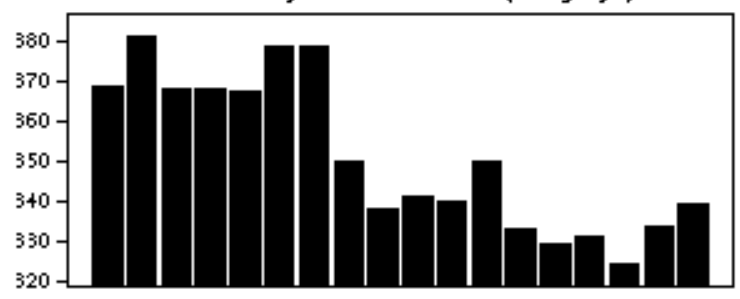

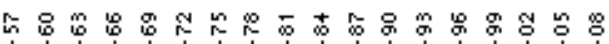

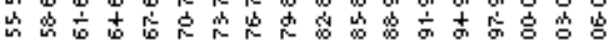

Figure 4.2. HMS Weather Data Averaged Over Three-Year Periods 

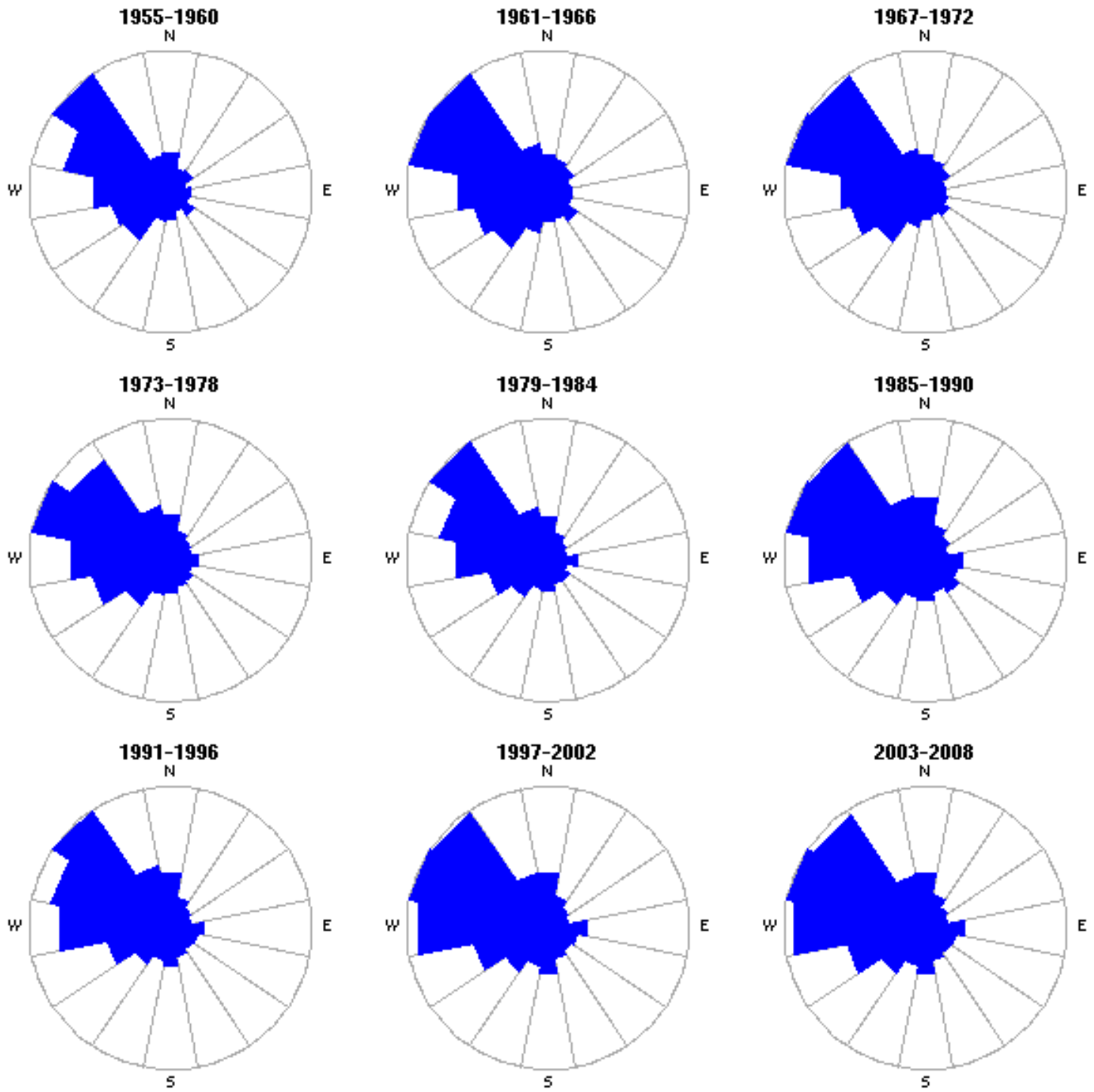

Figure 4.3. Windrose Plots Showing Prevalence of Wind Direction at HMS, Based on Counts of Wind Direction in 22.5-Degree Sectors. The predominant wind direction is from W-NW. 

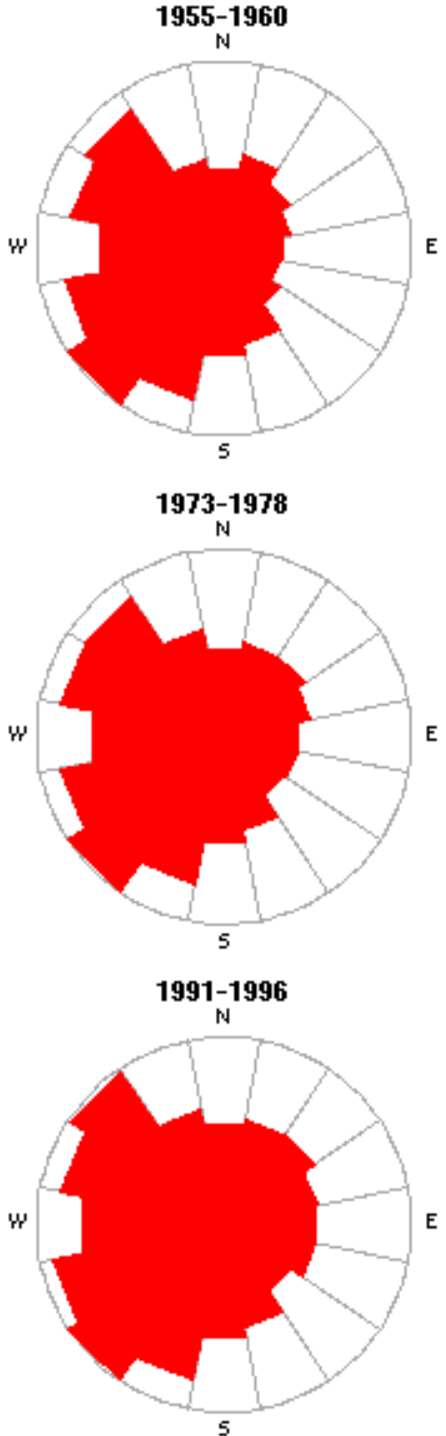
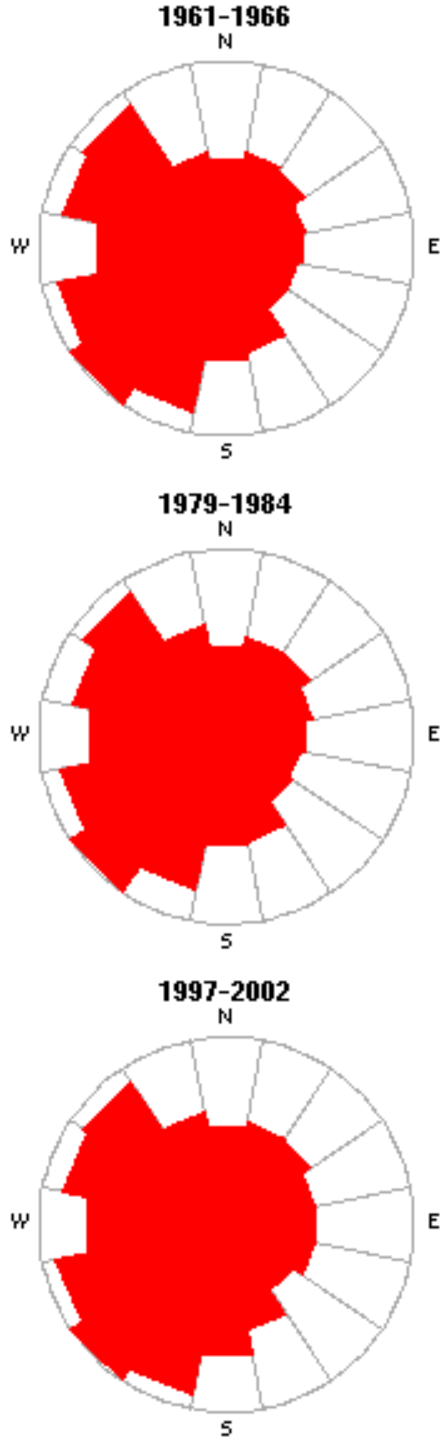
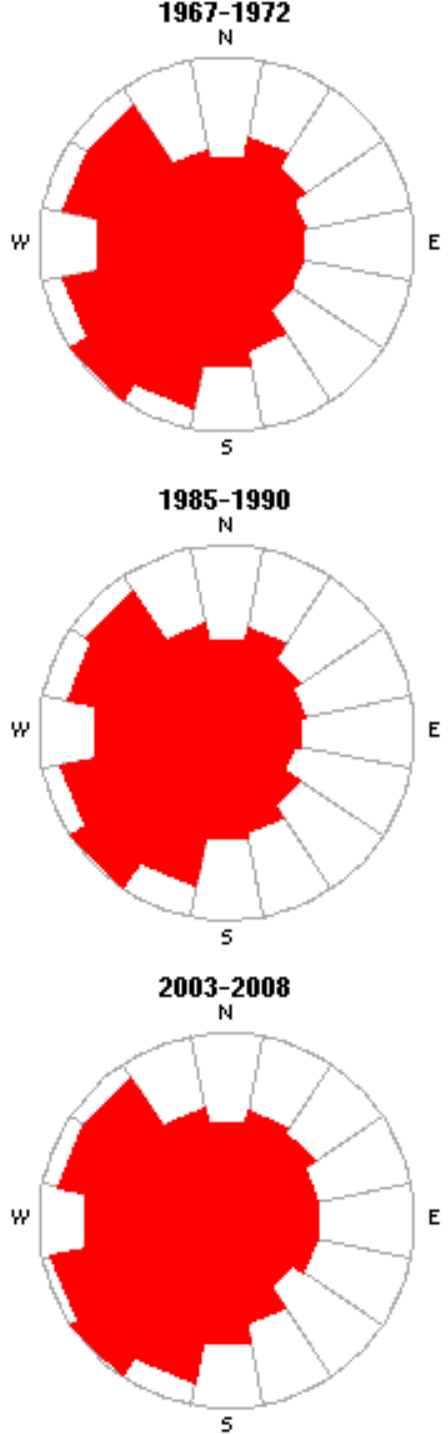

Figure 4.4. Windrose Plots Based on Means of Wind Speed in Each 22.5-Degree Sector for HMS Data. The peak gusts are usually from the SW. 


\section{Monthly Mean Temperature}
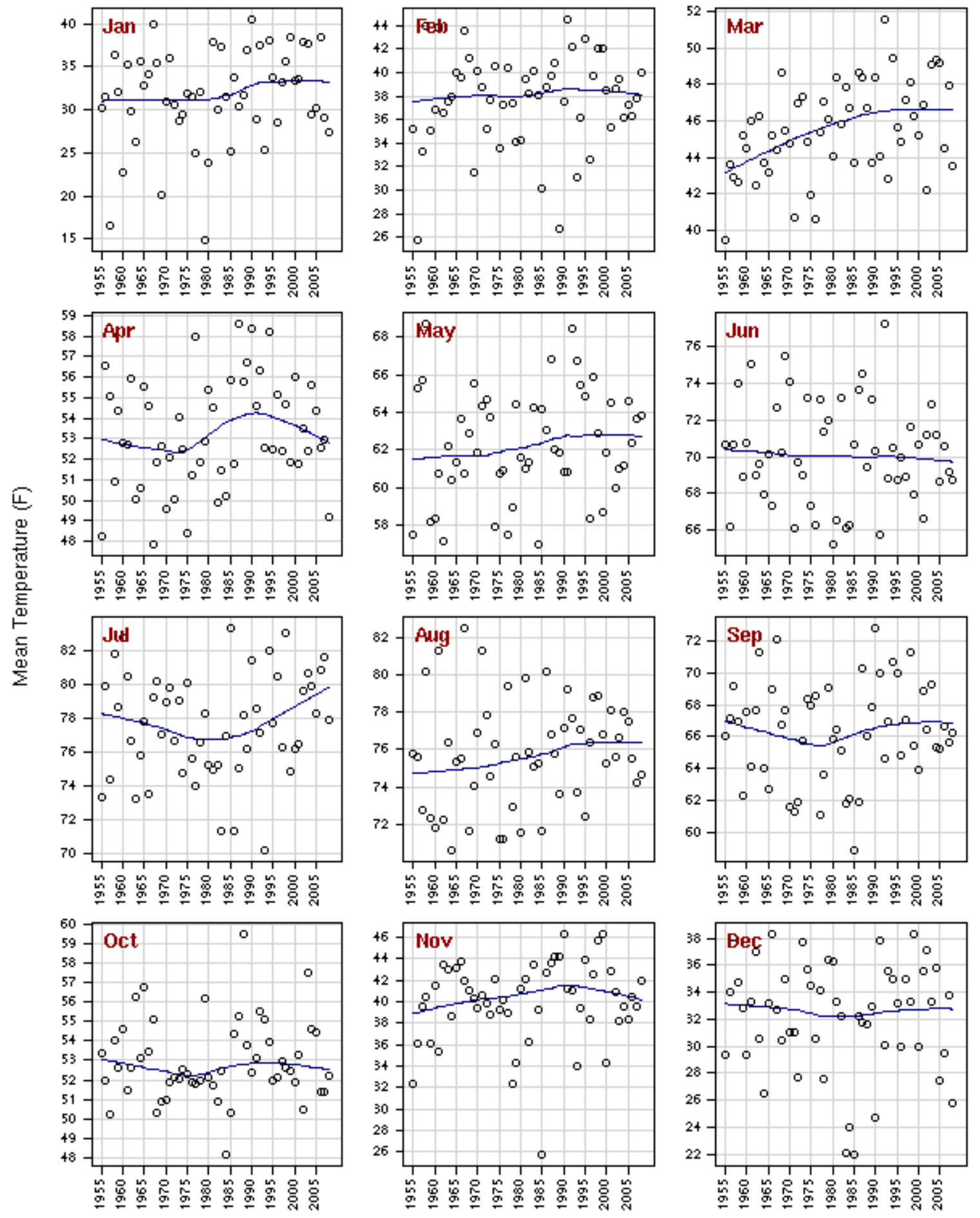

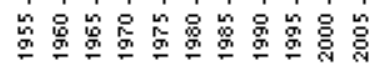

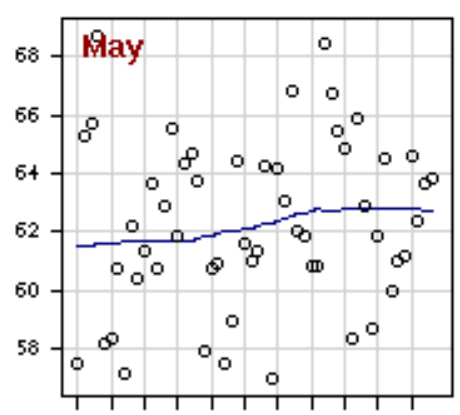

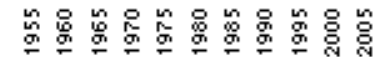
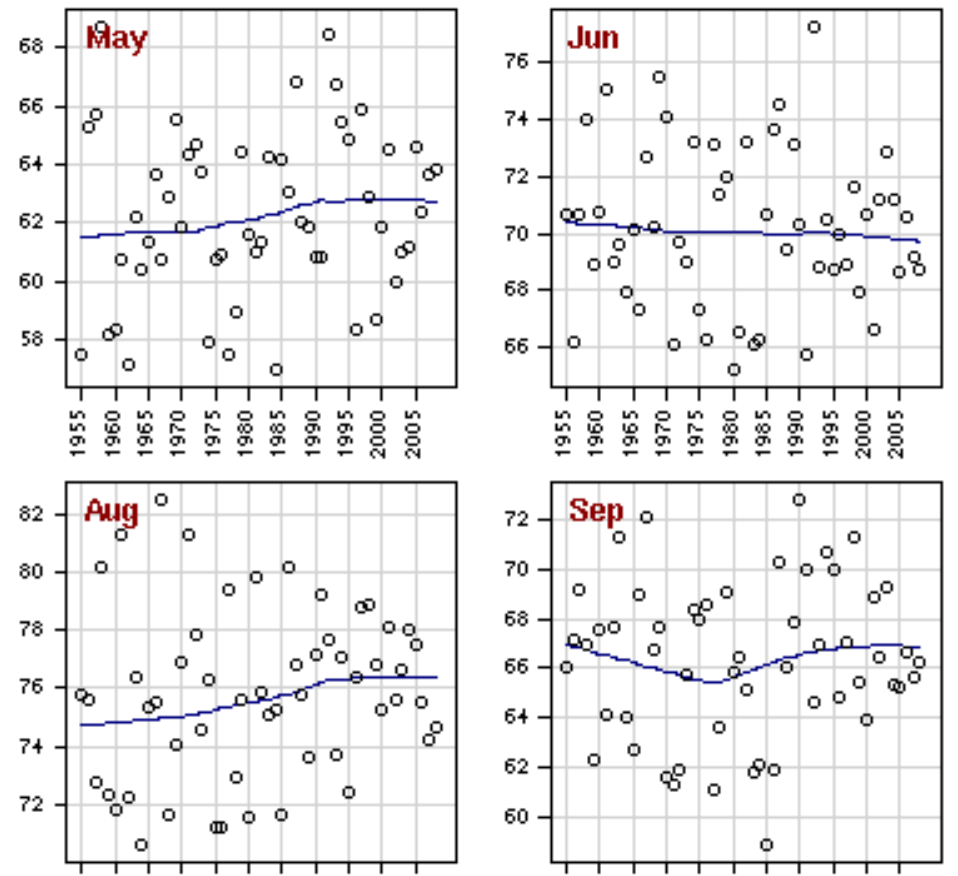

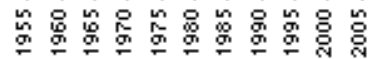

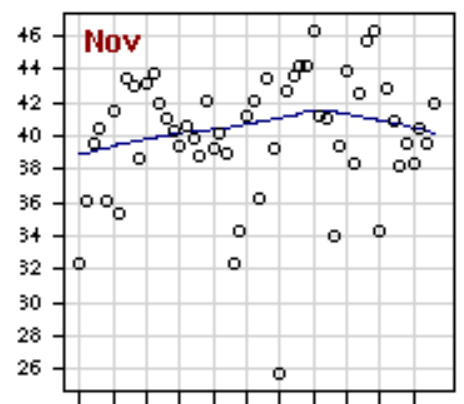

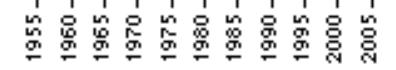

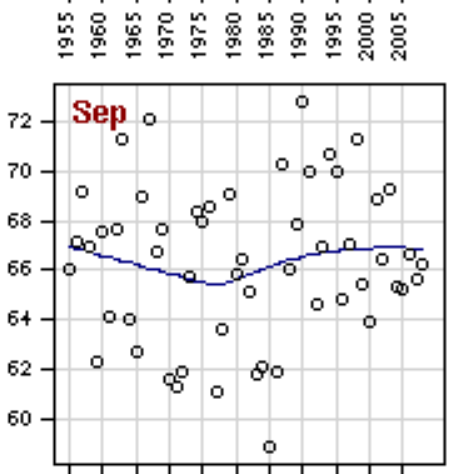

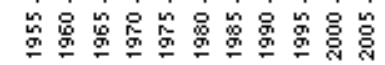

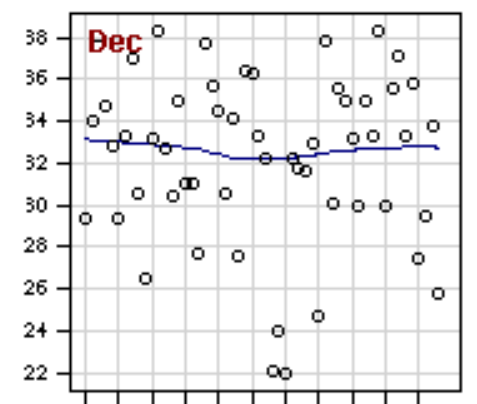

Date

Figure 4.5. Monthly Mean Temperature by Year Measured at the HMS, with Loess Lines 


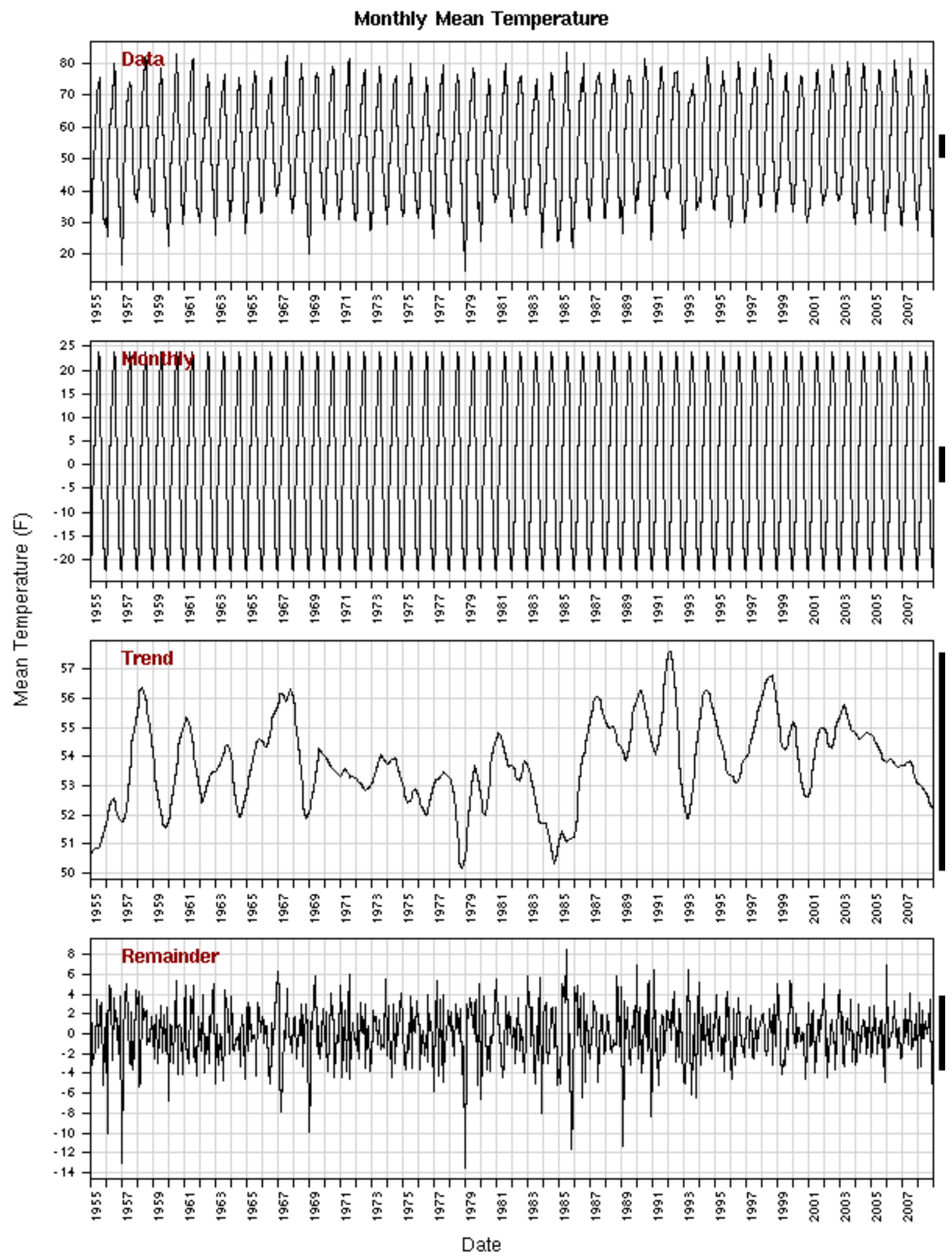

Figure 4.6. Seasonal Loess Applied to Mean Monthly Temperature at the HMS. Data $=$ Monthly + Trend + Remainder. 


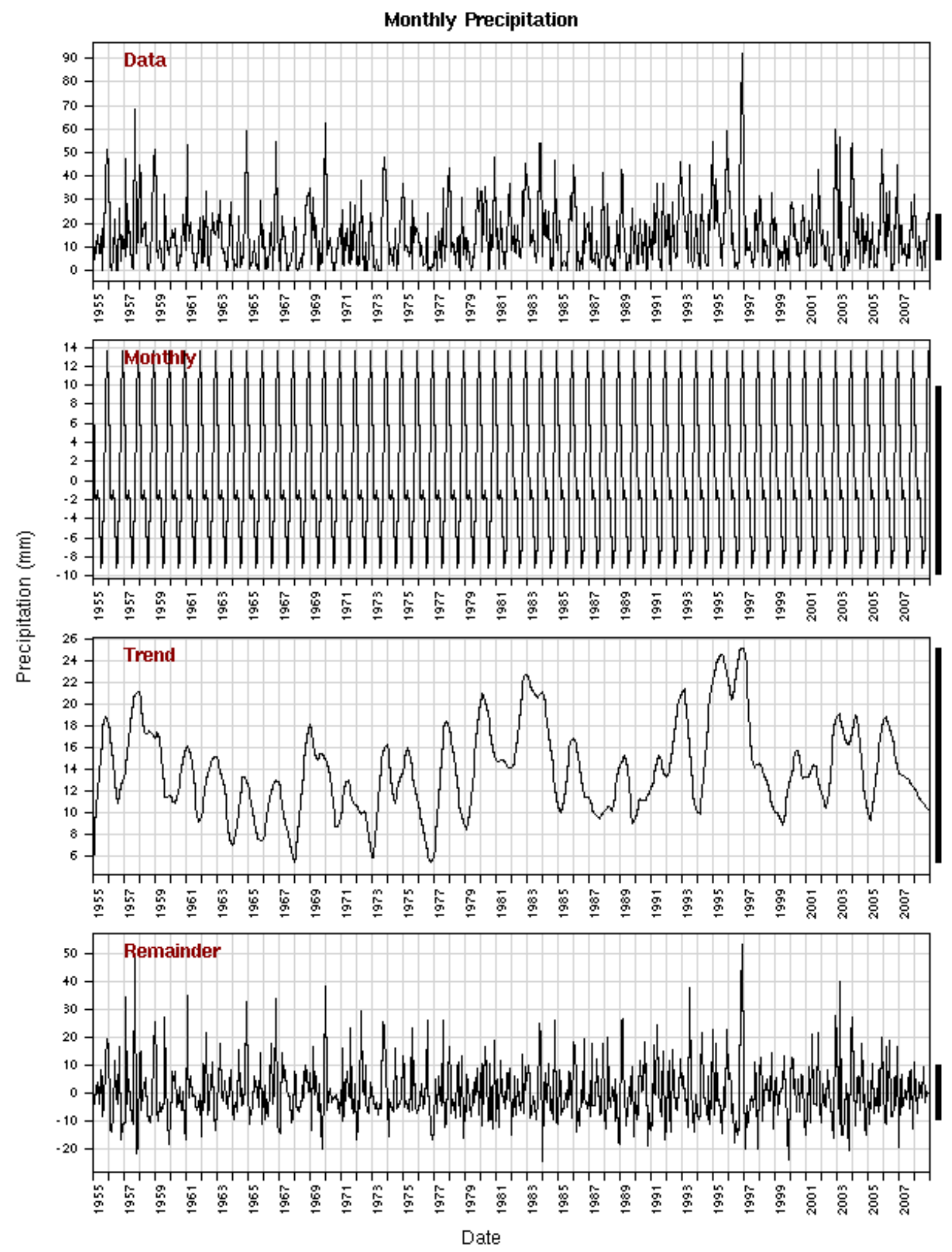

Figure 4.7. Seasonal Loess Applied to Precipitation Measured at the HMS 
The relative sizes of the components can be judged by referring to the black bars to the right of the graphs, which show the same absolute distance in units on each, different vertical axis. A component with a relatively short bar contains a relatively large proportion of the total variation in the data, as compared to a component with a relatively long bar. For example, the monthly component of mean temperature is the largest one, and the remainder term is the second largest. These indicate that seasonal and random variations comprise most of the variability in temperature. The trend component, though smaller, does show frequent changes on the order of 3 degrees over cycles of 1 to 3 years.

The remainder term is the dominant one for precipitation (Figure 4.7) and the snow variables, indicating again how important random variation is in determining these variables.

Overall, there do not appear to be any persistent long-term trends that would significantly impact natural recharge. However, there is significant inter-annual variability in addition to the more familiar seasonal variability. It is to be expected that recharge will vary significantly not only from year-to-year, but even in the averages of different multi-year periods. 
[This page intentionally left blank] 


\subsection{Recharge Data Collected in FY 2004-2009}

Monitoring of water flux and related properties (e.g. water content, matric potential) has been performed at various locations for different periods at the Hanford Site. Several monitoring locations, both active and inactive, are shown on the site map in Figure 5.1. The monitoring sites, activities, and periods for each site are listed in Table 5.1. Monitoring data for active sites are presented and examined in this section on a site-by-site basis.

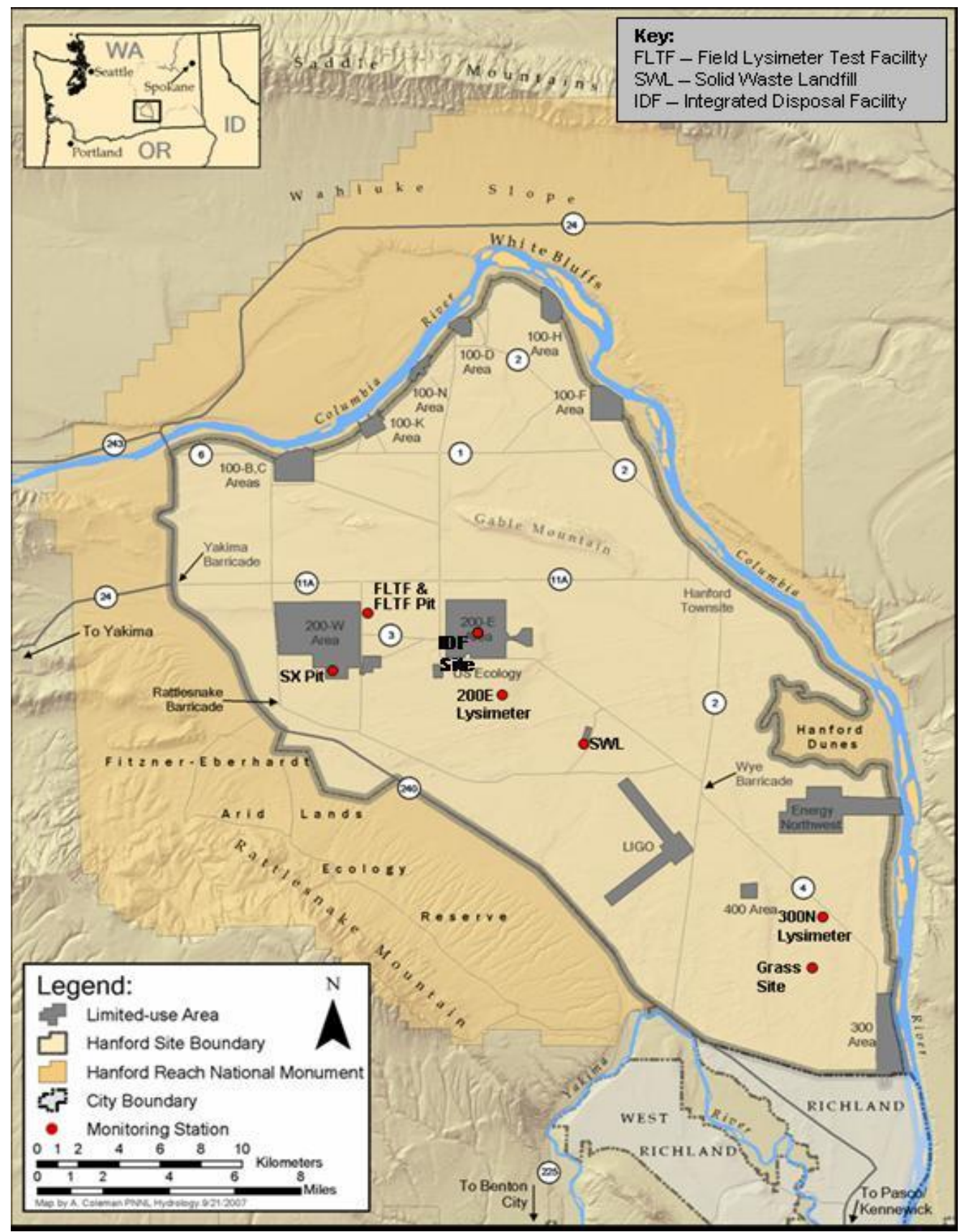

Figure 5.1. Location of Recharge Monitoring Stations at the Hanford Site 
Table 5.1. Monitoring Sites, Activities, and Periods

\begin{tabular}{lll}
\hline Monitoring Site & \multicolumn{1}{c}{ Monitoring Activities } & \multicolumn{1}{c}{ Monitoring Periods } \\
\hline Grass Site & Water flux, water content & 1-Feb-2005 to present \\
300N Lysimeter & $\begin{array}{l}\text { Water flux, water content, } \\
\text { matric potential }\end{array}$ & $\begin{array}{l}\text { 1981 - December 2006 } \\
\text { (Wind damage outage) } \\
\text { February 2007 - present }\end{array}$ \\
\hline Solid Waste Landfill ${ }^{\text {(a) }}$ & Water flux, water content & December 2004 to present \\
$\begin{array}{l}\text { Integrated Disposal Facility } \\
\text { (IDF) }\end{array}$ & $\begin{array}{l}\text { Environmental tracer methods, } \\
\text { water content }\end{array}$ & 2000-2008 \\
\hline 200 East Lysimeter & Water content & 1991 to 2007 \\
$\begin{array}{l}\text { Field Lysimeter Test } \\
\text { Facility (FLTF) }\end{array}$ & $\begin{array}{l}\text { Water flux, water content, } \\
\text { matric potential }\end{array}$ & 1987 to present \\
$\begin{array}{l}\text { Field Lysimeter Test } \\
\text { Facility (FLTF) Pit }\end{array}$ & Water flux & 2001 to present \\
Tank Farms & B: Water flux, water content & $\begin{array}{l}\text { B: From 2001 to 2003 } \\
\text { SX: From January 2003 to Sept. 2007 }\end{array}$ \\
\hline
\end{tabular}

(a) Leachate data from the SWL has been collected since 1996.

\subsection{Grass Site}

The Grass Site is located approximately $4.5 \mathrm{~km}$ northwest of the 300 Area in a location dominated by stabilized sand dunes. Layered soil conditions exist at the site with a sandy loam to loamy sand soil present from the surface to a depth of approximately $40 \mathrm{~cm}$ followed by a sandy soil. Vegetation at the Grass Site is predominately annual and perennial grass. In 2005 a recharge monitoring station consisting of duplicate WFMs and two water content sensors was installed at this location. WFMs were installed keeping the layered soil column intact. Additional information about the Grass Site and the installation of monitoring equipment can be found in Keller and Gee (2005) ${ }^{1}$. Figure 5.2 shows photographs of the grass-covered surface of the two WFMs at this site in the autumn of 2006. Note that the exposed tops of these WFMs are both $20-\mathrm{cm}$ in diameter.

The water content and cumulative drainage since instrument installation are presented in Figures 5.3 and 5.4, respectively. Changes in water content are consistent with seasonal precipitation trends (i.e. wet winters and dry summers). Increased water content is observed in the sand layer (60 cm bgs sensor) underlying the sandy loam layer. This signifies that the soil profile wets up enough to overcome the capillary break formed by this layering.

\footnotetext{
${ }^{1}$ Keller JM and GW Gee. 2005. "Remediation Decision Support / Characterization of Systems Fiscal Year 2005 Recharge Task Status Report”. Letter Report to George Last, PNNL, September 10, 2005.
} 


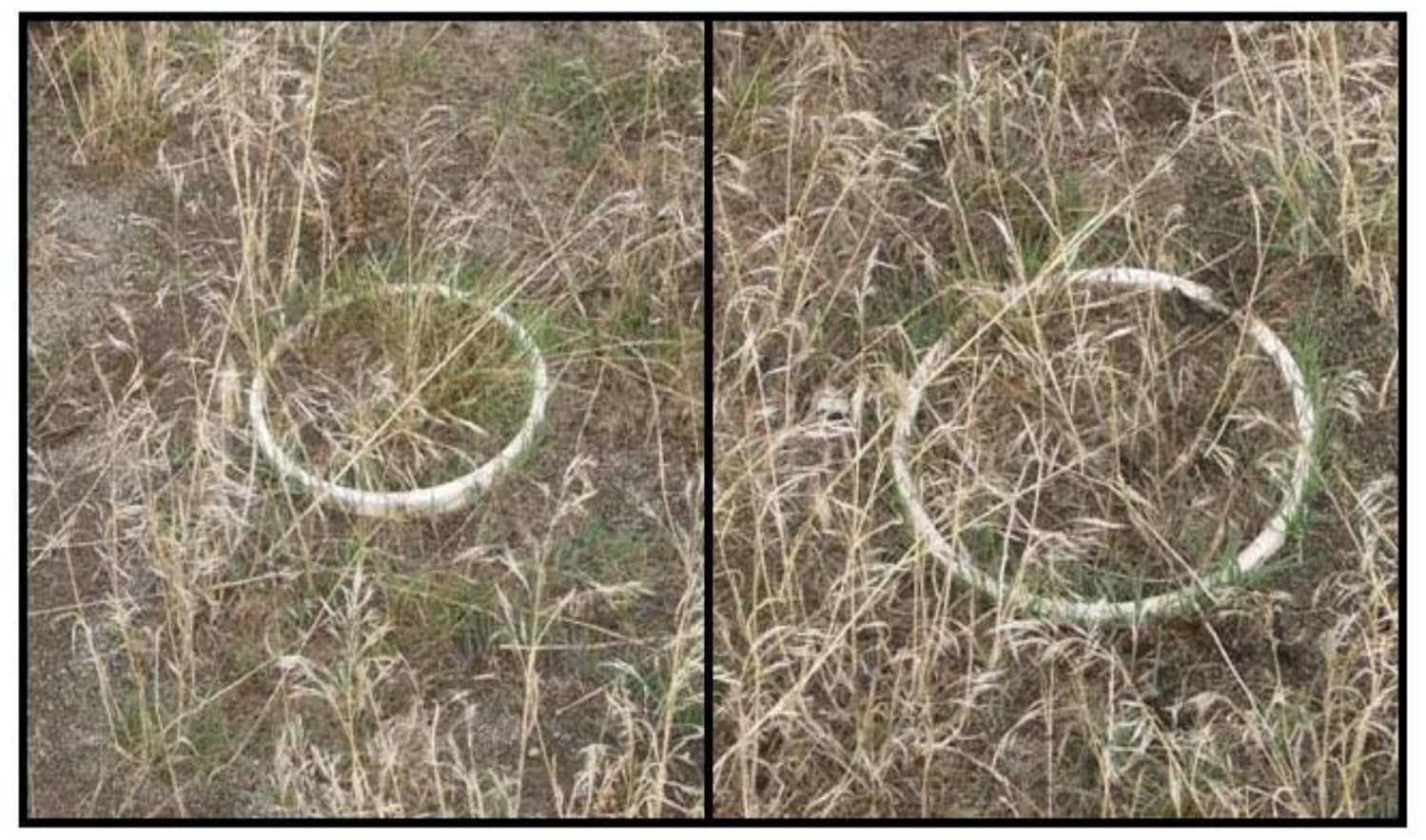

Figure 5.2. Surface Conditions on the Water Flux Meters at the Grass Site in Autumn 2006. The Exposed Tops of these Water Flux Meters are 20-cm in Diameter.

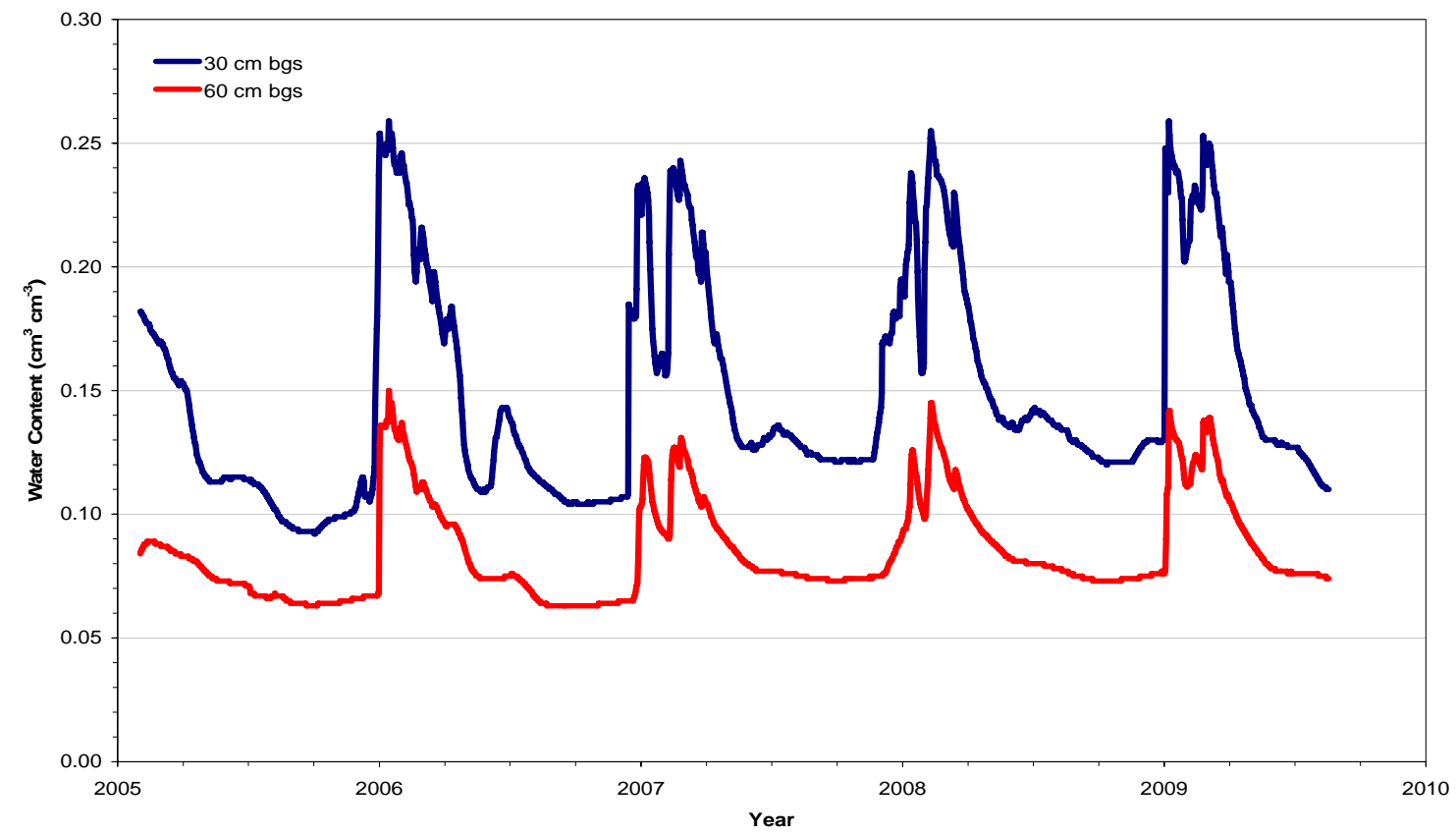

Figure 5.3. Volumetric Water Content Measured at 30 and $60 \mathrm{~cm}$ Below Ground Surface at the Grass Site. 


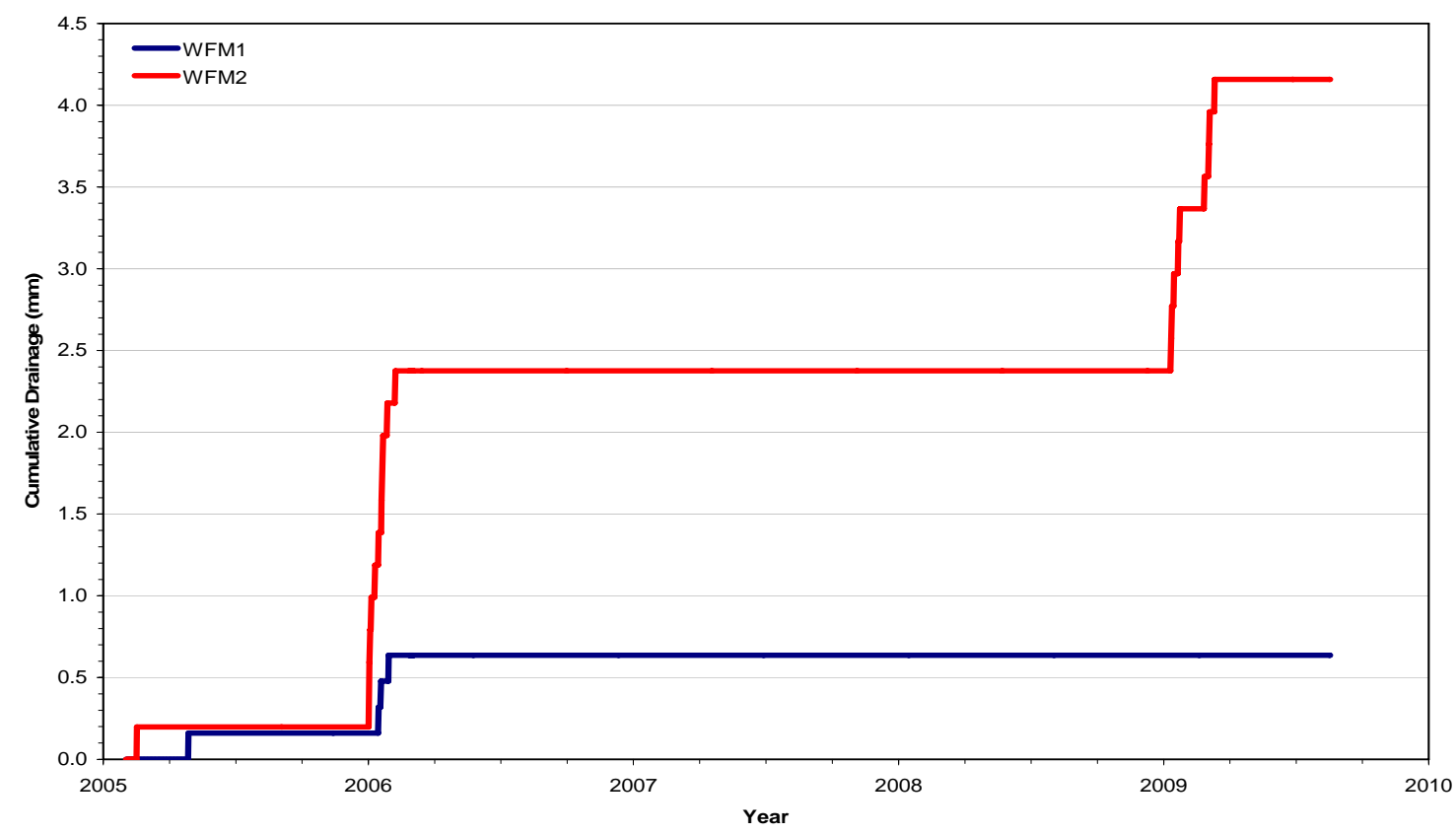

Figure 5.4. Cumulative Drainage Measured at the Grass Site Using Water Flux Meters.

The water content sensors at the Grass Site have performed remarkably well over the past 4.5 years. However, drainage amounts to date are markedly different between both flux meters (4.16 mm vs. $0.64 \mathrm{~mm}$ ), possibly reflecting the variability in soil properties. This may be natural variation or a result of differences brought about during installation of the WFMs. The latter is probably more likely. The WFMs did not measure drainage in 2007 or 2008, but 1.76 mm of drainage was recorded for WFM2 in 2009.

\section{$5.2300 \mathrm{~N}$ Lysimeter}

The 300-N Lysimeter site is located about $10 \mathrm{~km}$ north of Richland, Washington, just south of the Fast Flux Test Facility (FFTF), and within $300 \mathrm{~m}$ of the 300 Area Burial Grounds (618-10). A series of lysimeters designed for water-balance studies and to simulate waste-burial-grounds with bare, coarsegrained surfaces was constructed at this site in 1978. Detailed descriptions of the site are provided by Gee and Jones (1985), Gee et al. (1992), and Sisson et al. (2002). Other instrumentation includes a Pronamic rain gage installed at the drainage outlet in the bottom of the lysimeter in August 2000. This rain gage was connected electronically to a data logger to measure drainage on a continuous basis. In April 2002, two WFMs were also installed in the south lysimeter and connected to the datalogger.

Presently the 300-N Lysimeter site consists of two $2.7 \mathrm{~m}$ diameter, $7.6 \mathrm{~m}$ deep caissons, and four $0.6 \mathrm{~m}$ diameter, $7.6 \mathrm{~m}$ deep caissons. Monitoring of natural recharge (deep drainage) at this site is restricted to one of these, the south caisson. The south caisson lysimeter is filled with Hanford formation sediment screened to contain less than one percent gravel (material $>2 \mathrm{~mm}$ ). The lysimeter has remained essentially void of vegetation over its lifetime.

Automated measurement of drainage from the bottom of the lysimeter is accomplished using a tipping spoon gauge. In addition to this water flux measurement, two WFMs are installed within the lysimeter near the soil surface. Water content and matric potential profiles within the south caisson 
lysimeter are also monitored, as is matric potential outside the lysimeter at the $7.5 \mathrm{~m}$ depth. Additional information about the 300N Lysimeter Site and instrumentation can be found in Phillips et al. (1979) and Sisson et al. (2002).

In December 2006 a windstorm produced a peak gust of $74 \mathrm{mph}$ (a record for the month of December) at the Hanford Meteorological Station (HMS). This windstorm blew over the 300N Lysimeter tripod that housed the datalogger and other measurement control devices. The resulting damage to the datalogger and power supply as well as to the associated wiring was substantial. Soon after the damage at the site was identified, efforts were made to repair and reconnect wiring as well as to better secure the tripod at this location. By February of 2007 the site was again operational, except for the datalogger switch ports controlling the WFMs. In the process of reconstructing the site it was recognized that many undocumented and unused instruments were at the site and that the datalogger program was outdated. An evaluation of instrumentation and the datalogger was performed and a decision made to overhaul the site. This effort included removing unnecessary code from the datalogger program, removing unused sensors from the site, checking functionality of equipment, and encasing all wiring. Because the datalogger switch ports no longer functioned and with consideration given to the age of the dataloggers and the fact that technical support for this model was being phased out by the manufacturer, a new datalogger was purchased for this site. In August of 2007 the new datalogger was installed. By the end of August 2007 the overhaul of the $300 \mathrm{~N}$ Lysimeter Site was complete. This effort significantly streamlined operation of the site and extended the operation of this critical facility. Figure 5.5 shows the surface of the $300 \mathrm{~N}$ Lysimeter Site after completion of the overhaul.

The key measurement at this site is drainage from the bottom of the south caisson lysimeter. Figure 5.6 depicts cumulative drainage from this lysimeter for the period ending August 18, 2009. From the onset of drainage in 1981 to August 18, 2009 the drainage rate has averaged $62.6 \mathrm{~mm} / \mathrm{yr}$. During the time that the monitoring system was down in December 2006 and January 2007 due to the wind damage outage, drainage from the base of the lysimeter was not measured. Given the length of the drainage record at this site, the absence of this data does not significantly affect the reported average drainage rate.

Measured water contents and matric potentials at this site for FY 2007-2009 are shown in Figures 5.7 and Figure 5.8, respectively. The water content data displays increases in water content in response to the onset of winter precipitation and drying of the profile into the drier spring and summer months in each year. The datalogger at the 300N lysimeter site started to record periodic NAN ("not a number") values from the water content sensors in February 2008. Later in the year periodic NAN values also started to appear for some of the matric potential sensors. Inspection of the wiring and datalogger connections at the field site did not reveal any obvious problems. The periodic NAN values generally occurred between the hours of 8PM and 4AM, during periods in which the air temperature was dropping, which suggested that this problem could possibly be a result of condensation on the datalogger/sensor leads inside the datalogger enclosure. 


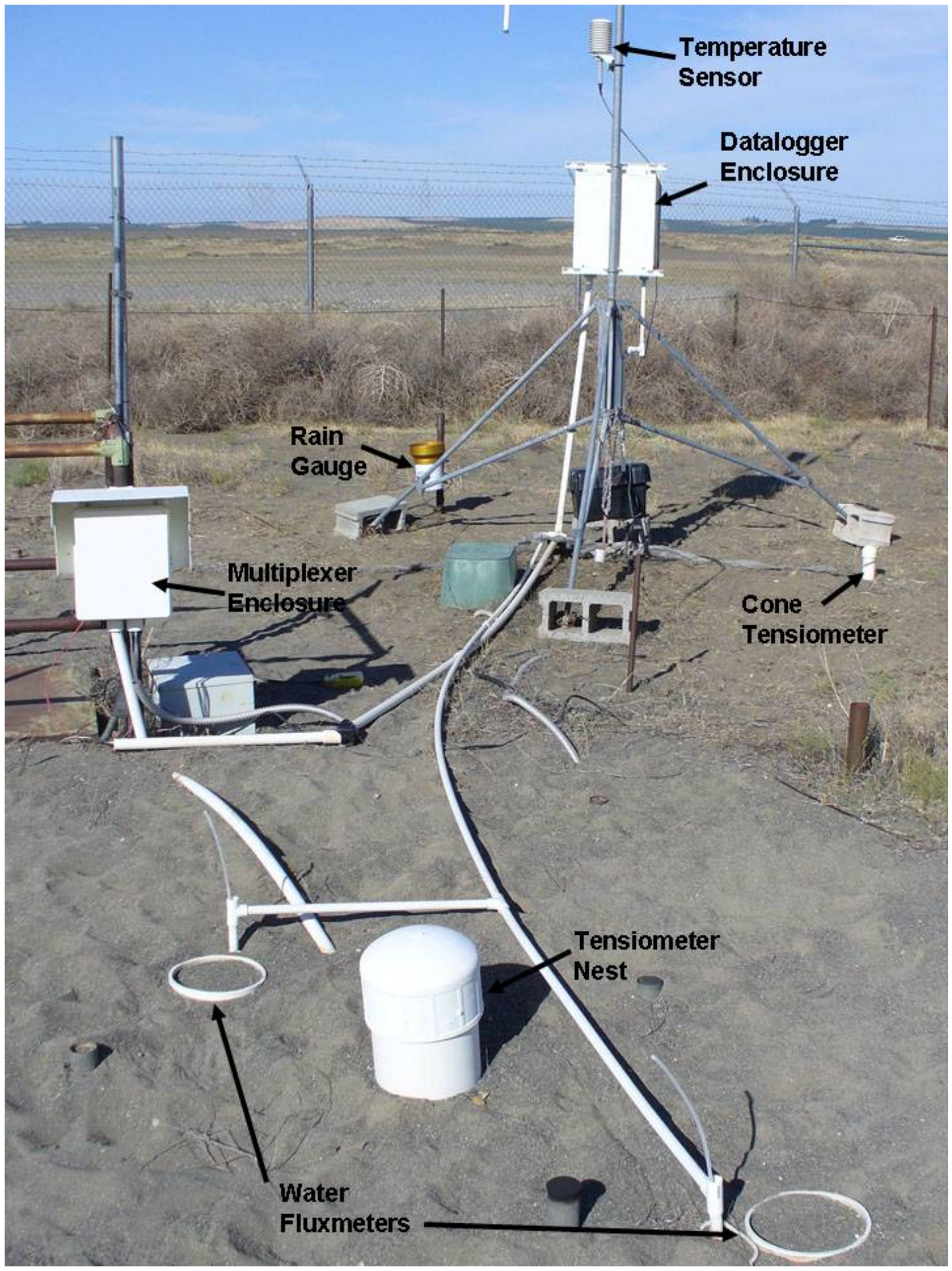

Figure 5.5. Surface Conditions of $300 \mathrm{~N}$ Lysimeter Site on September 13, 2007. The coarse textured sand in the foreground is the approximate location of the south caisson. 


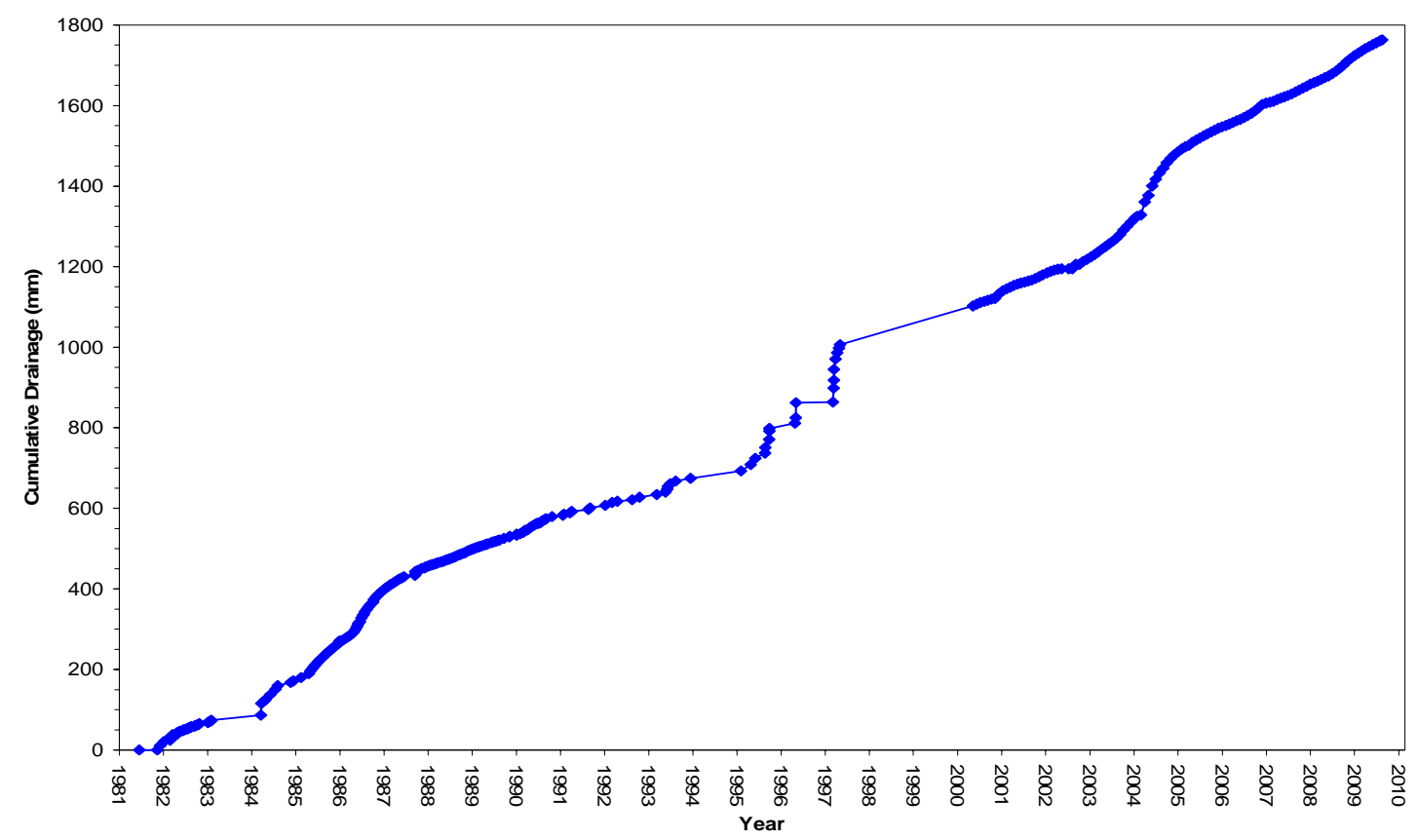

Figure 5.6. Cumulative Drainage Measured Since 1981 from the South Caisson at the 300N Lysimeter Site

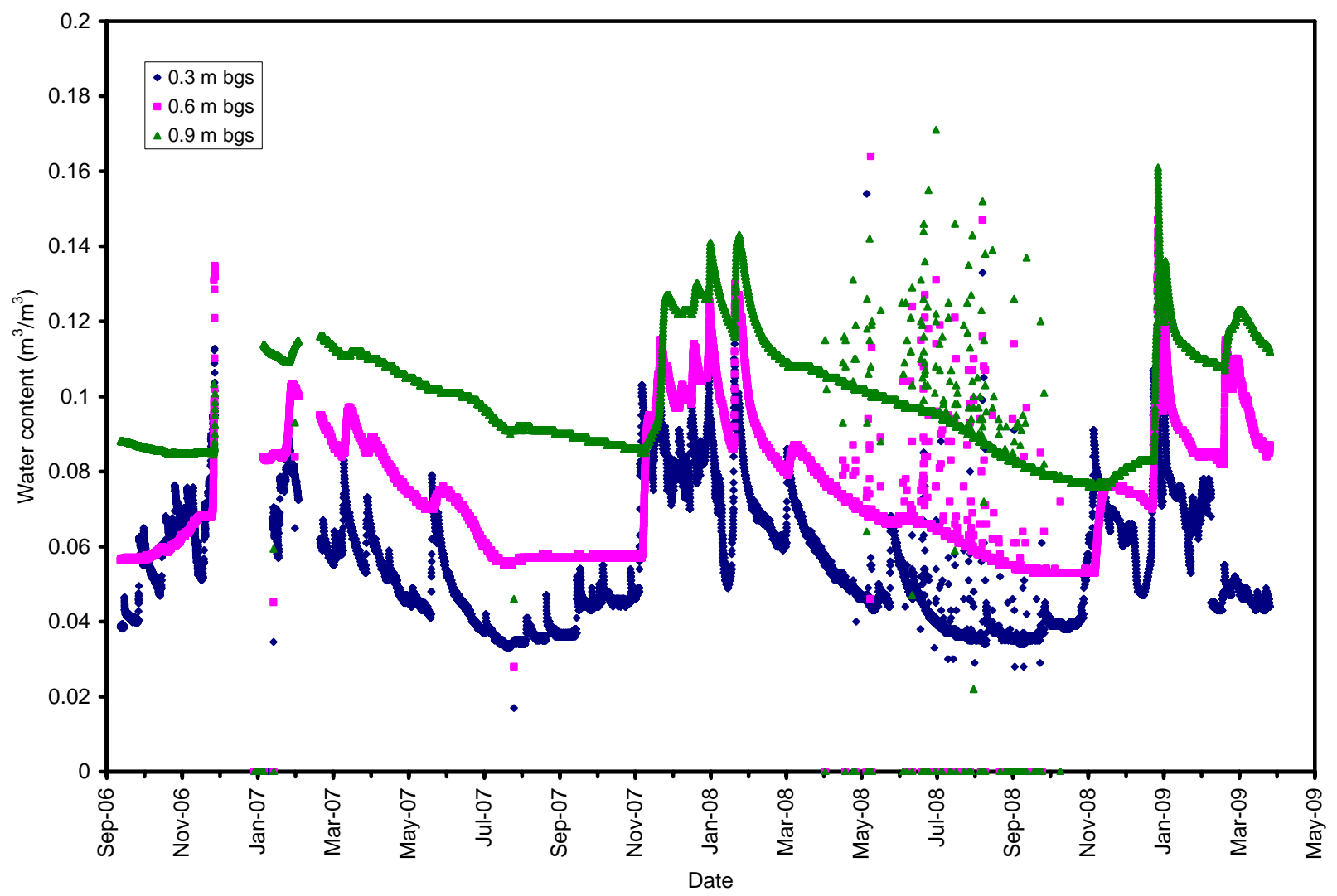

Figure 5.7. $300 \mathrm{~N}$ Lysimeter Water Contents Measured at 0.3, 0.6, and $0.9 \mathrm{~m}$ Below Ground Surface 


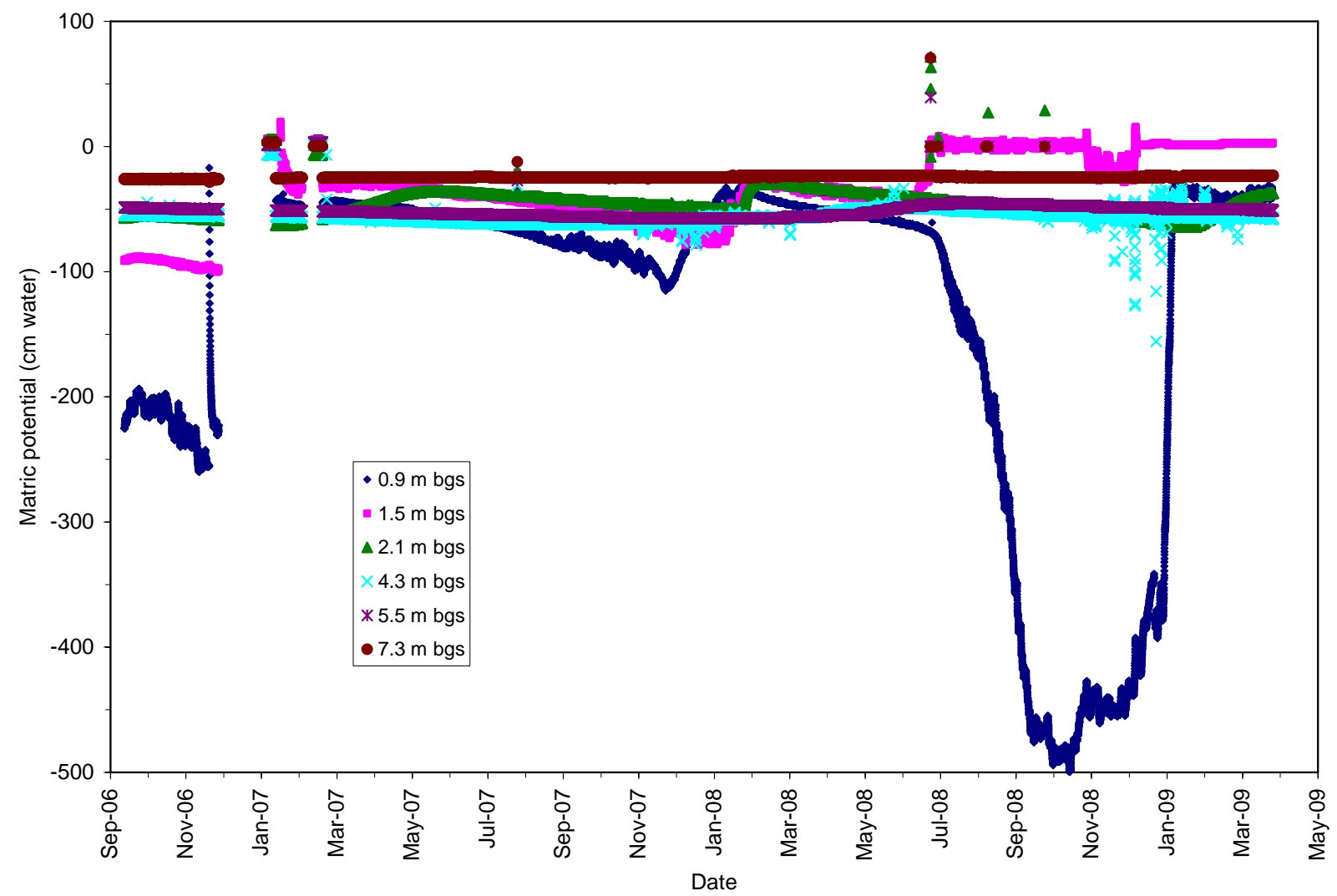

Figure 5.8. 300N Lysimeter Matric Potentials Measured at Six Depths.

Desiccant was added to datalogger enclosure in September 2008 and this seemed to resolve the problem, until March 2009. In FY09 a new project was started at the 300N lysimeter site to study the possible role of colloids in radionuclide transport. This project, whose principal investigator is Dr. Markus Flury of Washington State University, is supported by the DOE, Office of Science, Environmental Remediation Sciences Program (ERSP). The PNNL lead for this project was originally Dr. Glendon Gee who is now retired. The current PNNL lead for the project is Dr. Fred Zhang.

All six of the caissons at the 300N lysimeter facility are being used for this ERSP project. Field work for this project began in March 2009. On March 11, 2009, $3 \mathrm{~mm}$ of water containing a colloid with a stable Europium isotope was added to the south caisson and to three of the small caissons (Personal communication with Fred Zhang, March 24, 2009). The water application to the south caisson was a onetime addition, since this caisson is being monitored for long-term drainage rates. The water added to one of the small caissons also contained a $\mathrm{KBr}$ tracer. On March 24, 2009, $3 \mathrm{~mm}$ of water containing a colloid with stable Europium isotope was added to the north caisson and $6 \mathrm{~mm}$ of water with colloid was applied to the fourth small caisson. Water is being added periodically to all of the other caissons, except for the south caisson, to increase the rate of transport of the colloids and tracer.

The water content sensors appeared to be performing well from October 2008 through early-March 2009 at which point the datalogger again started recording spurious "NaN" values and significantly lower apparent water content values for all three water content sensors. Initial efforts to identify the problem 
were unsuccessful. A recent site visit and more thorough investigation revealed that the water content probes had been nearly pulled out of the ground, apparently during preparation of the ground surface prior to water and colloid additions for the ERSP project described above. The probes were still partially covered with sand so this problem was not immediately obvious in the field. The probes were reinstalled to their correct depths in early September 2009 and fresh dessicant was also added to the datalogger enclosure. The water content probes now appear to be functioning properly again.

The matric potential data measured by tensiometers within the lysimeter are shown in Figure 5.8. The data are relatively predictable for some time periods with the near surface sensors exhibiting a drying profile into the spring and summer. The $0.9 \mathrm{~m}$ depth sensor prior to the December 2006 wind damage recorded uncharacteristic matric potential data, as did the $1.5 \mathrm{~m}$ depth sensor just after the system was repaired in early February 2007.

Figure 5.9 shows matric potential data from a cone penetrometer tensiometer located outside of the lysimeter at the $7.5 \mathrm{~m}$ depth. Although there is considerable scatter in the data from this sensor, the trend of the matric potential data fluctuates between about 24 and $34 \mathrm{~cm}$ over the three-year period that is shown. This range is consistent with the data from the tensiometer located at the 7.3-m-depth within the lysimeter (Figure 5.8) that indicates a relatively constant value of $\sim 25 \mathrm{~cm}$.

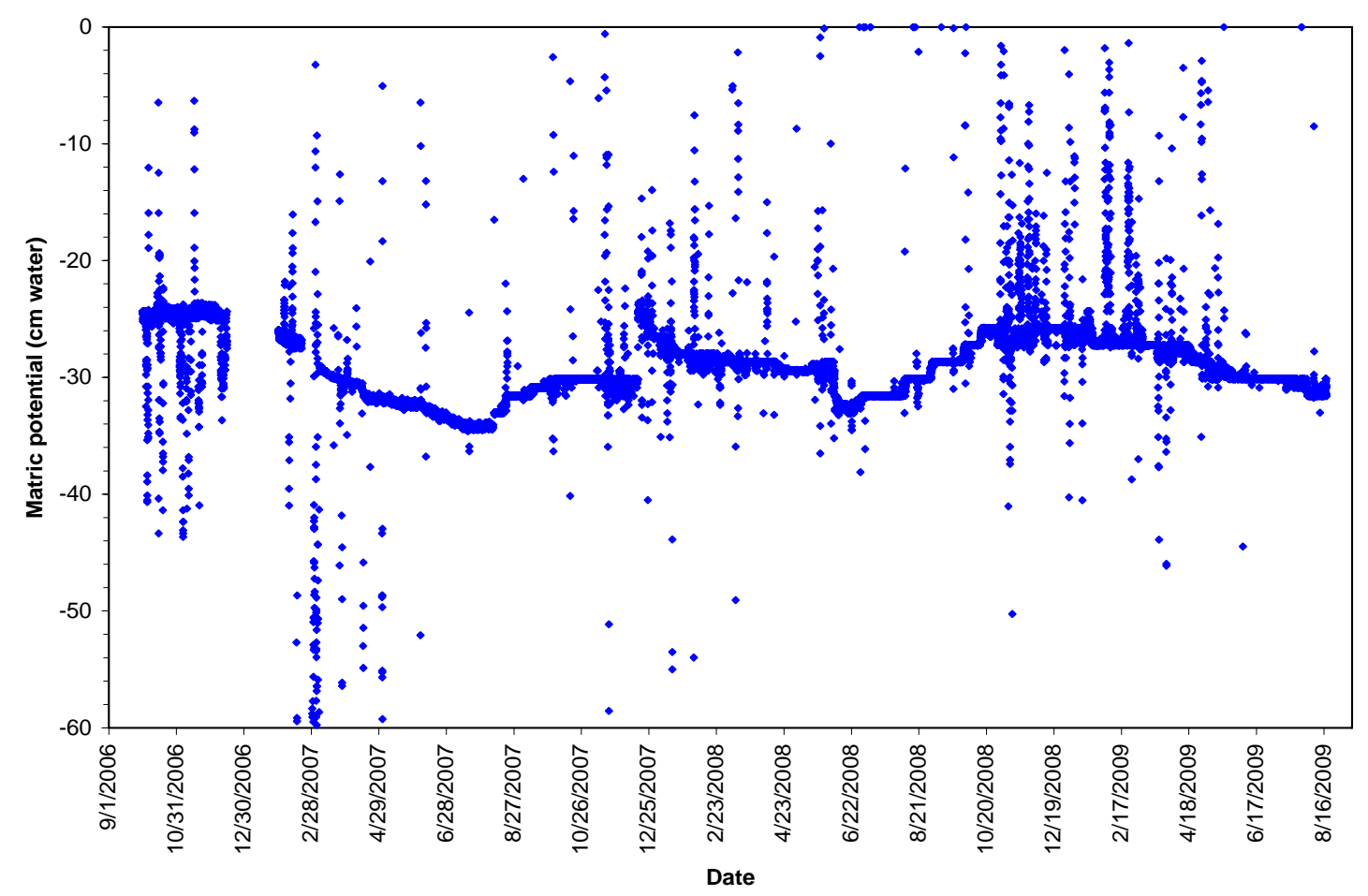

Figure 5.9. $300 \mathrm{~N}$ Lysimeter Cone Penetrometer Tensiometer Matric Potentials Measured Outside of the South Caisson at $7.5 \mathrm{~m}$ Below Ground Surface (unfiltered data). 


\subsection{Solid Waste Landfill (SWL)}

The Hanford SWL is located in the 600 Area approximately $6.5 \mathrm{~km}$ northwest of the Wye Barricade. At this location are two duplicate WFMs and three water content sensors. The WFMs are filled with gravelly sand material that includes large cobbles (Figure 5.10). The surfaces of the WFMs are void of vegetation. The water content sensors are placed in similar soil adjacent to the WFMs. Additional information about the instruments can be found in Keller and Gee (2005) ${ }^{1}$. Also at this site is a large (capture area of $85 \mathrm{~m}^{2}$ ) basin lysimeter placed at the bottom of the landfill trench and filled with nonorganic waste thoroughly mixed with Hanford formation sediments (Wittreich and Wilson 1991). The surface material above the basin lysimeter is not as cobbly as the WFMs but is still very coarse. In addition, the basin lysimeter surface is vegetated with a sparse population of Indian Ricegrass (Figure 5.11). Measurement of the basin lysimeter drainage is carried out by a separate project, but the RACS project does maintain the data record for the basin lysimeter.

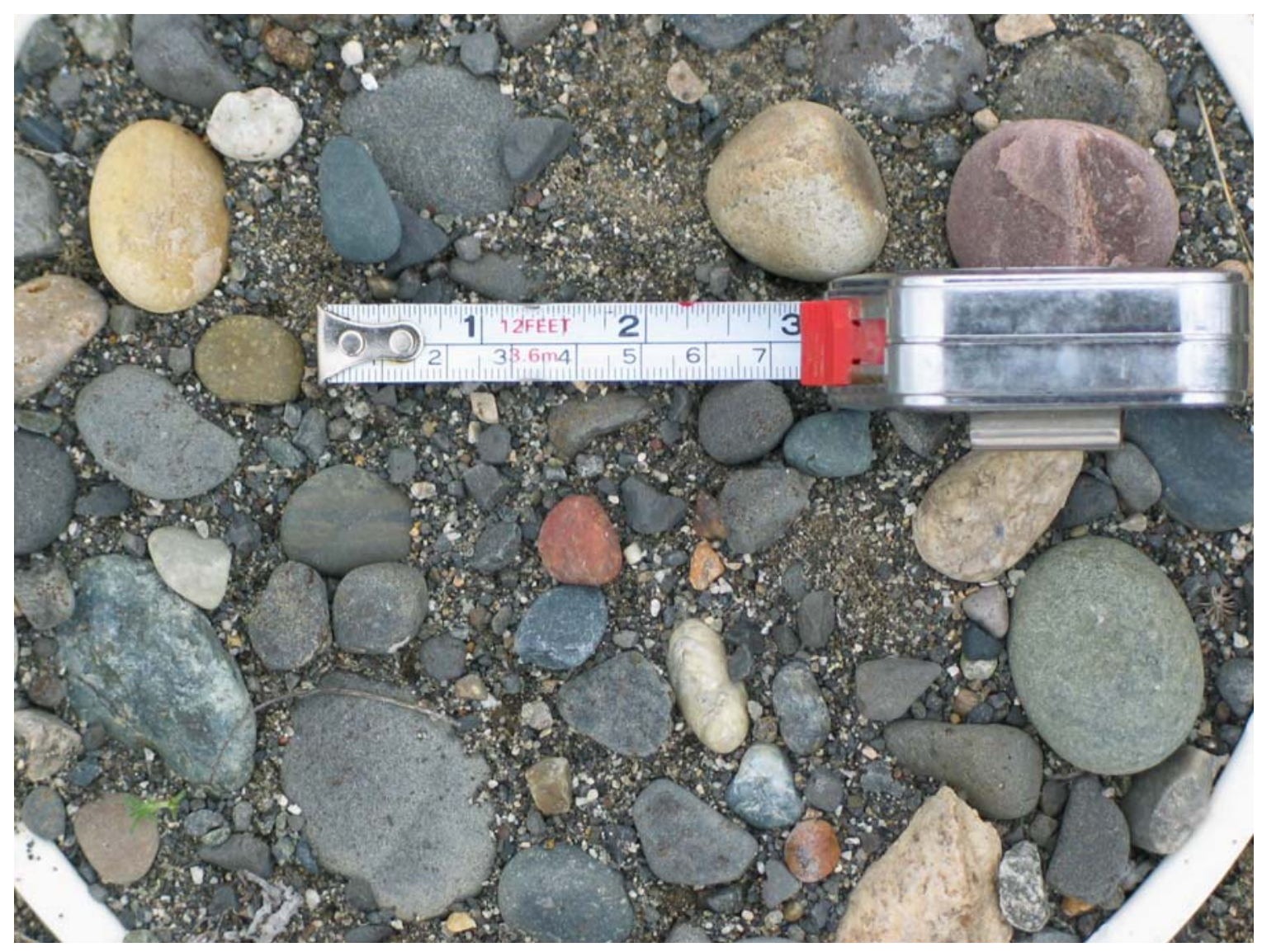

Figure 5.10.WFM Material at the Hanford SWL

\footnotetext{
${ }^{1}$ Keller JM and GW Gee. 2005. "Remediation Decision Support / Characterization of Systems Fiscal Year 2005 Recharge Task Status Report”. Letter Report to George Last, PNNL, September 10, 2005.
} 


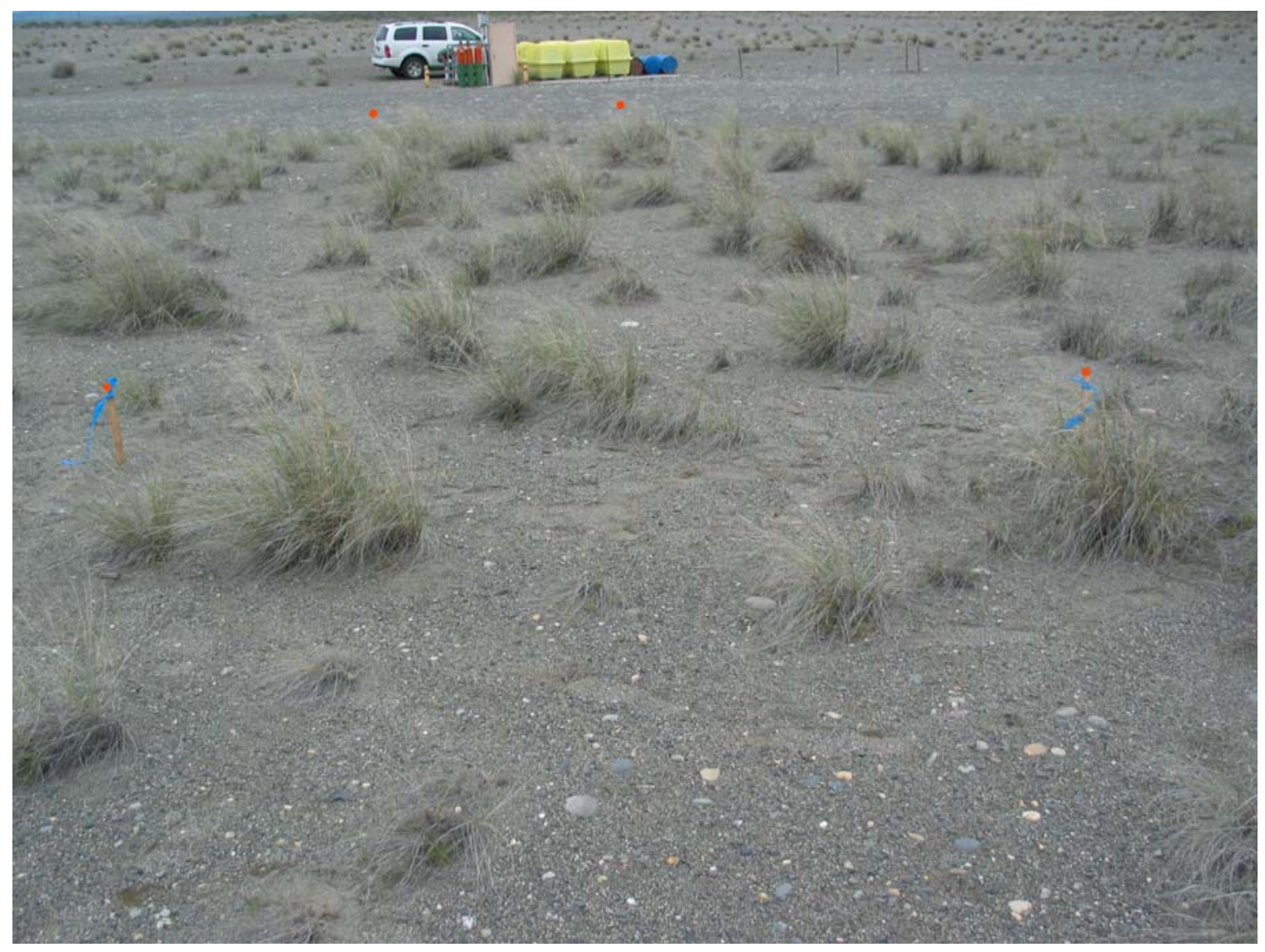

Figure 5.11. SWL Basin Lysimeter (orange dots represent approximate corners of the basin lysimeter)

Figure 5.12 shows the sensor-measured water content from December 2004 through August 2009. As expected, the water content at all depths display seasonal variation in accordance with the wet winter months and dry summer months. The SWL dataset has a gap (missing data) from May 14, 2008 through March 26, 2009. The SWL is a remote site that does not have a phone line or a telemetry system. The data logging equipment runs on batteries that are recharged by solar panels. Data are uploaded manually during periodic site visits. The datalogger has the capacity to store data for in excess of 6 months with hourly measurement frequency before it overwrites memory. However, if equipment problems occur between site visits, we have no knowledge of them until after the data are uploaded during the next site visit.

During FY08, the last site visit prior to writing of the year-end recharge summary report (Nichols et al. 2008) was on May 14, 2008. Funding for recharge field site monitoring was temporarily discontinued in August, 2008 and was not resumed again until late-January, 2009 after a change in the Hanford Site contractors (from Fluor-Hanford to CHPRC) that are supporting the recharge monitoring efforts. When the SWL site was revisited in early February 2009, the data logger was found to be without power and battery was dead. All data that had been recorded after May 14, 2008 were lost.

Initial efforts to restore the site by recharging the battery were unsuccessful. After replacing a voltage regulator and battery, it was determined that one of the water content sensors had a short and was drawing excessive power that could not be maintained by the battery and solar panel. 


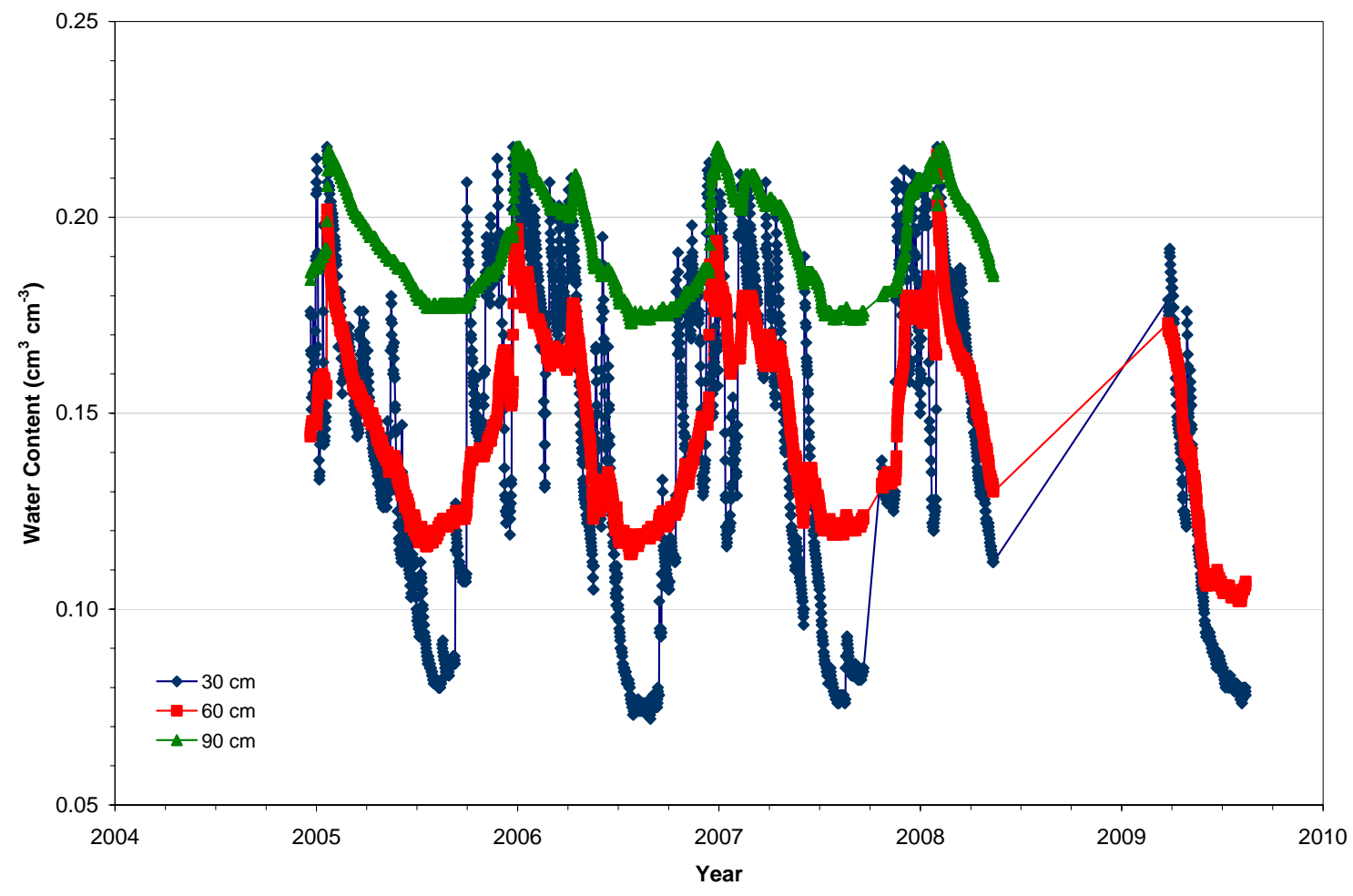

Figure 5.12. Volumetric Water Contents Measured at the SWL Site at 30, 60, and $90 \mathrm{~cm}$ Below Ground Surface

This water content sensor was disconnected from the datalogger and logging of the other sensors at the SWL site resumed on March 26, 2009. The faulty water content sensor at the SWL has not yet been replaced, but this is recommended.

Figure 5.13 shows the WFM measured drainage at this location. Beginning in March of 2007 the second WFM (WFM 2) measured significantly less drainage than the first WFM (WFM 1). A site visit determined that a plant had established itself next to the WFM 2, but outside of the divergence control tube, and the plant canopy was intercepting precipitation. As a result, in FY 2007 WFM 2 measured nearly $75 \mathrm{~mm}$ less drainage than did WFM 1 . This affirms the significance of plant canopies in limiting recharge by capturing precipitation before it reaches the ground surface. The plant near WFM 2 was removed at that time, and any other plants in the vicinity of the WFMs are removed whenever they are noticed during site visits.

The data collected for January 31, 2008 and Feb 1, 2008 showed an excessive number of "tips" were recorded for WFM-2 in particular, but also for WFM-1. Although this could possibly be attributed, in part, to snowmelt and runon, it is also possible that a "spill event" may have occurred. A similar event was noted on January 19, 2005. The data shown in Figure 5.13 include corrections for these events. Although the evidence for spills is not conclusive, such spills could occur when the carboy located in an instrument caisson at this site used to store leachate is hauled to the surface to take away for emptying. If this carboy is accidentally tipped during transfer, the WFMs, which are installed very near the top of the caisson, could detect the additional water. 


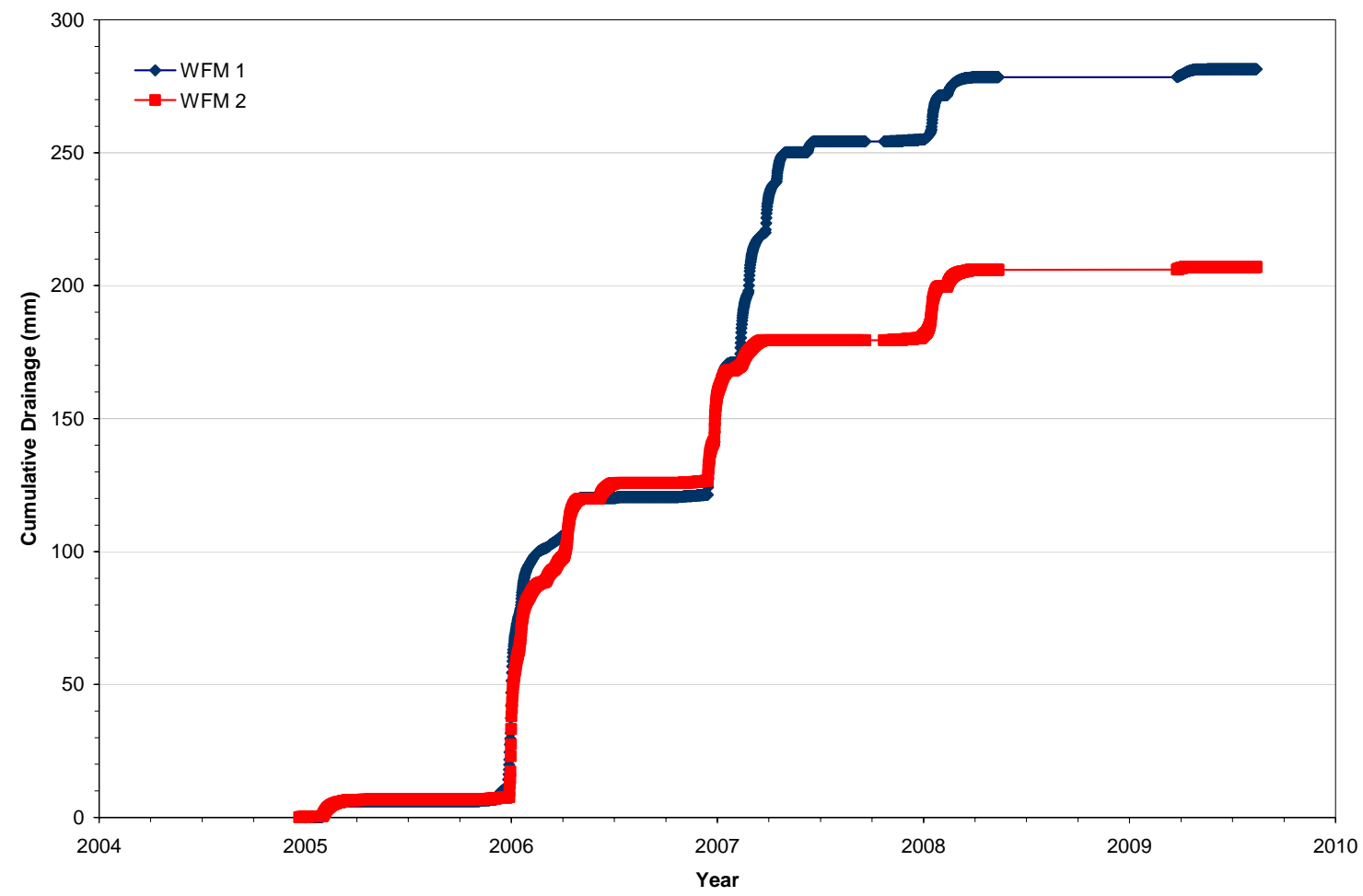

Figure 5.13. Cumulative Drainage Measured at the SWL Using Water Flux Meters Since December 21, 2004.

These spill events are speculative. Nevertheless, considering these possible spill events and other factors, such as the ability of plants to quickly establish themselves on the WFMs, and the infrequent site visits that can result in data losses if equipment failures occur, we consider the drainage measured from the basin lysimeter to be much more reliable than the WFMs for estimating long-term recharge rates at this site.

A plot of the drainage intercepted by the basin lysimeter is depicted in Figure 5.14. From July 1, 1996 to August 20, 2009, the average recharge calculated based on the basin lysimeter data was 50.3 $\mathrm{mm} / \mathrm{yr}$. This represents $\sim 29 \%$ of the total precipitation that was recorded at the HMS during that time period. The rate of drainage appears to be greater in FY09 relative to FY08, but similar to the rates seen in FY03 and FY04.

\subsubsection{Vegetation Characterization}

Nichols et al. (2008) describe the results of a vegetation survey that was performed at the SWL site in August 2008. The surface of the SWL is dominated by bare ground with an average live plant cover of about $24 \%$. This plant cover is mainly large bunchgrasses (Indian Ricegrass) with a minor component of cheatgrass scattered between bunchgrass clumps. Interested readers are referred to Nichols et al. (2008) for further details regarding this vegetation survey. 


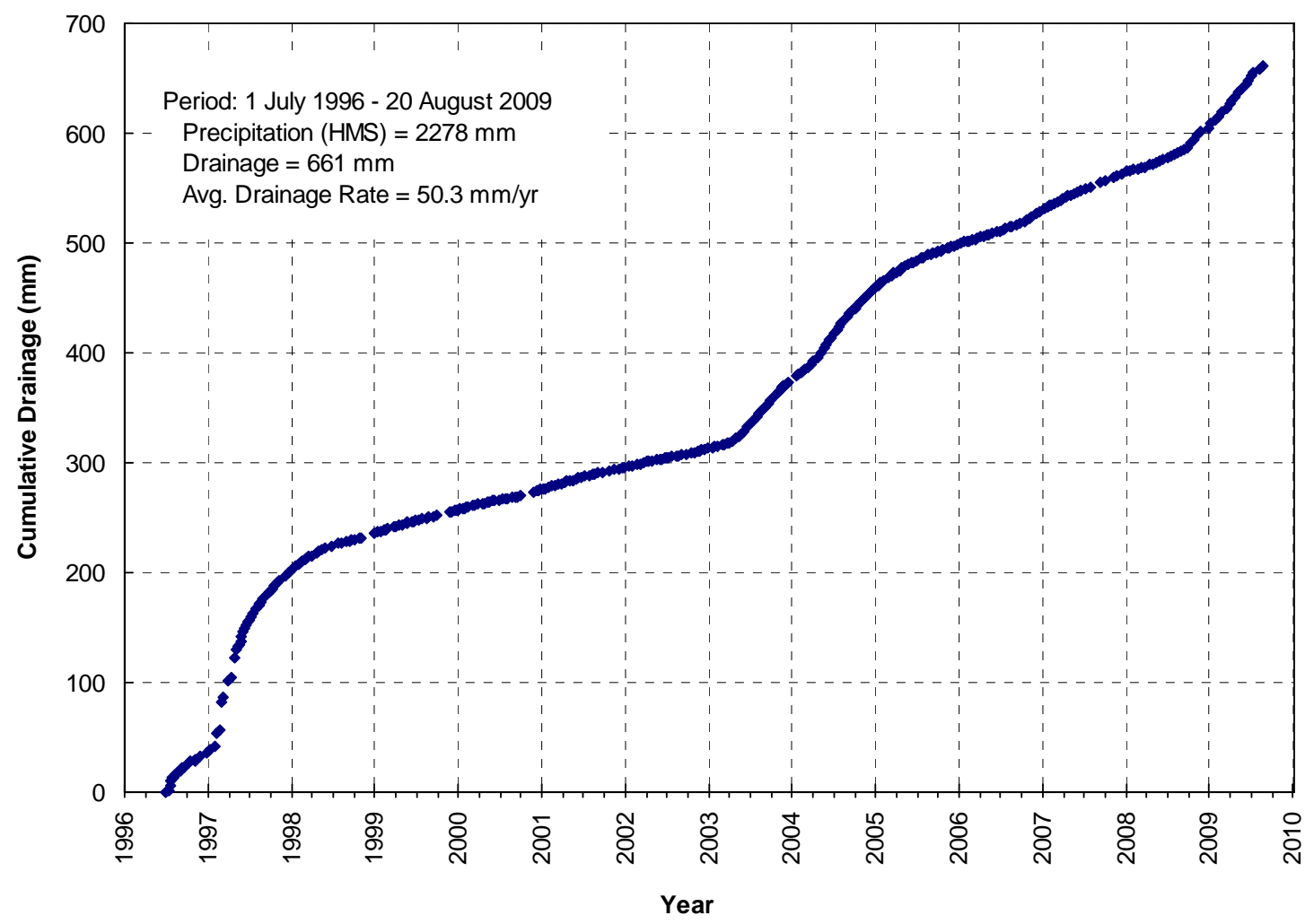

Figure 5.14. Cumulative Drainage Measured at the SWL from the Basin Lysimeter Since July 1, 1996.

It is interesting to note that the average drainage rate of $50.3 \mathrm{~mm} / \mathrm{yr}$ determined from the 13-year record of data for the sparsely vegetated SWL basin lysimeter is almost as great as the average rate of $62.6 \mathrm{~mm} / \mathrm{yr}$ determined from the 29-year record of data for the unvegetated south caisson at the 300N lysimeter facility. The sediments at the SWL site are somewhat coarser than those filling the south caisson at the $300 \mathrm{~N}$ lysimeter facility and the SWL is sparsely vegetated, but the long-term average drainage rates are nevertheless similar.

\subsection{Integrated Disposal Facility (IDF)}

The IDF site is located on the south side of the Cold Creek bar, a depositional bar left in the lee of the Umtanum Ridge during Pleistocene cataclysmic flooding. This bar is dominated by gravel on the north side (closest to the main flood channels) grading to fine sand on the south side. A long, stabilized dune occupies the southern end of the IDF site. The presence of the dune at the IDF site indicates a history of sand dune activity in this area following the last cataclysmic flood $(\sim 13,000$ years ago). The dune represents the northern fringe of a large dune field that exists below and south of the Central Plateau. The dune is stabilized by a very healthy stand of shrub-steppe vegetation and is not actively growing or migrating (the dune will eventually be removed during construction of the IDF). The nearest active dune to the IDF site is approximately $3 \mathrm{~km}$ south of this area (Gaylord and Stetler 1994).

Recharge for the IDF site has been estimated using environmental tracers. For the immobilized lowactivity waste (ILAW) 2001 Performance Assessment, Fayer et al. (1999) used the chloride and chlorine36 tracer techniques to estimate recharge rates. For the 2005 IDF PA, two tracer techniques were used: 
chloride mass balance (CMB) and deuterium and oxygen-18 (Fayer and Szecsody 2004). A description of these two techniques can be found in Appendix B of Fayer and Szecsody (2004).

Neutron probe measurements of soil moisture were collected at this site from a series of 16 access tubes located in different vegetation regimes from 2000 through 2008. No measurements were made at the IDF site in 2009 because precipitation levels were normal, suggesting that the frequency of neutron probe measurements could be reduced. Neutron probe monitoring of soil moisture at this site is expected to resume in FY10.

\subsection{Field Lysimeter Test Facility (FLTF)}

The Field Lysimeter Test Facility (FLTF) was originally constructed from November 1986 through June 1987 (Gee et al. 1989, Campbell et al. 1990) and is located adjacent to the HMS. There are three different lysimeters types at the FLTF: fourteen 3-m-deep by 2-m-diameter drainage lysimeters; six 3-mdeep by 0.3 -m-diameter small-tube lysimeters; and four $1.5-\mathrm{m}$ by 1.5 -m by $1.7-\mathrm{m}$-deep weighing lysimeters.

Figure 5.15 depicts an artist's rendering of the FLTF at the Hanford Site (Fayer and Gee 2006) showing the layout of the facility. Additional information about the facility and data collection prior to 2004 can be found in Fayer and Szecsody (2004). Under the Recharge Measurement task, drainage is measured from twelve of the drainage lysimeters, four of the small-tube lysimeters, and one of the weighing lysimeters. Automated hourly measurements of mass are made on all four weighing lysimeters. Additionally, tensions are measured in seven lysimeters at various depths. Temperatures within the lysimeters are also measured at over 50 locations, but those data are not summarized here. Of the 21 lysimeters being monitored, nine of them are regularly irrigated to mimic precipitation conditions that are three times greater than the long-term average ambient precipitation. Table 5.2 Summary of FLTF Treatments and Monitoring Periods - summarizes the test treatments for the monitored lysimeters. A brief description of each test is provided in Table 2.

The enhanced precipitation treatment is attained through irrigation that is applied to attain a target precipitation plus irrigation rate. Figures 5.16 through 5.21 illustrate the cumulative application rate and cumulative target rate for the FLTF water years ${ }^{1}$ 2004-2009. The enhanced precipitation treatment does not necessarily represent climatic conditions three times wetter than current climatic conditions. This is because a larger fraction of the enhanced precipitation is applied during spring and summer months when the atmosphere is relatively dry and warm than would be expected for a wetter climate. Consequently, the portion of the enhanced precipitation that is lost to evapotranspiration is likely greater than would be expected with an actual wetter climate with greater precipitation occurring in cooler months.

\footnotetext{
${ }^{1}$ A water year is a twelve-month period, usually selected to begin and end during a relative dry season, used as a basis for processing stream flow and other hydrologic data. The period from October 1 to September 30 is widely used in the United States, but other periods are also used depending on local climate conditions. The FLTF water year is designated to begin November 1 and end October 31; this period was selected based on considerations of local soil moisture and climatic patterns encountered at this facility.
} 


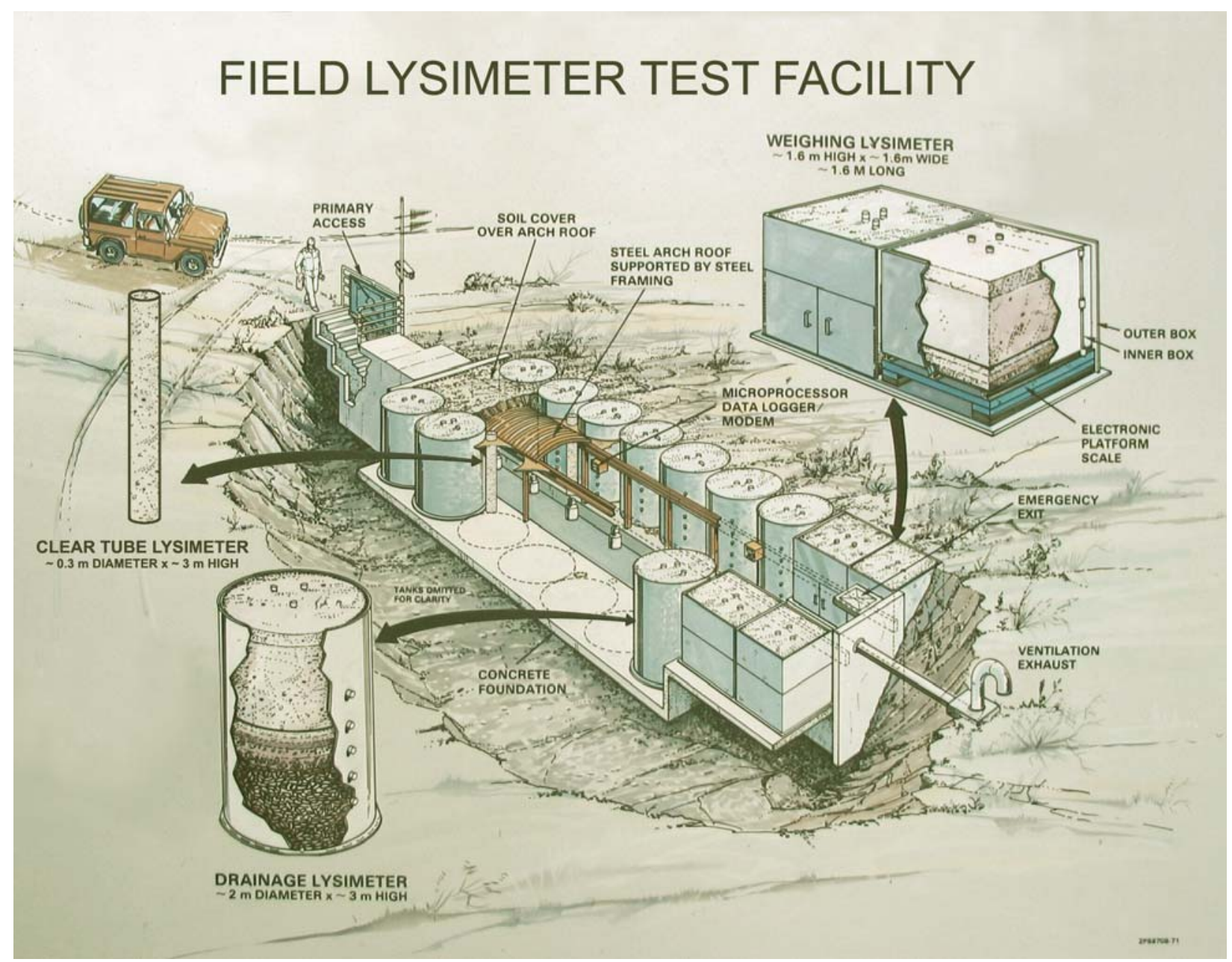

Figure 5.15. Artist's Rendering of the FLTF at the Hanford Site (Fayer and Gee 2006). 
Table 5.2. Summary of FLTF Treatments and Monitoring Period

\begin{tabular}{|c|c|c|c|c|c|c|c|c|c|}
\hline \multirow{2}{*}{$\begin{array}{c}\text { Test } \\
\text { Description }\end{array}$} & \multirow{2}{*}{$\begin{array}{c}\text { ID } \\
\text { Treatment }\end{array}$} & \multicolumn{2}{|c|}{ Precipitation } & \multicolumn{3}{|c|}{ Vegetation $^{(\mathrm{a})}$} & \multirow{2}{*}{$\begin{array}{c}\text { ID } \\
\text { Lysimeter }\end{array}$} & \multicolumn{2}{|c|}{ Monitoring Period } \\
\hline & & Ambient & Enhanced & NV & SRV & DRV & & Start & End \\
\hline \multirow{5}{*}{$\begin{array}{l}\text { Hanford } \\
\text { Barrier }\end{array}$} & 1 & $\checkmark$ & & & & $\checkmark$ & W1 & 4 Nov 87 & present \\
\hline & & $\checkmark$ & & & & $\checkmark$ & C3 & 9 Nov 88 & present \\
\hline & 2 & $\checkmark$ & & $\checkmark$ & & & $\mathrm{D} 1$ & 4 Nov 87 & present \\
\hline & 3 & & $\checkmark$ & & & $\checkmark$ & W3 & 4 Nov 87 & present \\
\hline & & & $\checkmark$ & & & $\checkmark$ & C6 & 9 Nov 87 & present \\
\hline \multirow{2}{*}{$\begin{array}{l}\text { Eroded } \\
\text { Hanford } \\
\text { Barrier }\end{array}$} & 6 & $\checkmark$ & & & & $\checkmark$ & D3 & 4 Nov 87 & present \\
\hline & 18 & & $\checkmark$ & & & $\checkmark$ & D13 & 27 May 98 & present \\
\hline \multirow{2}{*}{$\begin{array}{l}\text { Gravel } \\
\text { Mulch }\end{array}$} & 8 & $\checkmark$ & & $\checkmark$ & & & C1 & 17 Nov 89 & present \\
\hline & 10 & & $\checkmark$ & $\checkmark$ & & & $\mathrm{C} 4$ & 17 Nov 89 & present \\
\hline \multirow[t]{2}{*}{ Pitrun Sand } & 9 & $\checkmark$ & & & & $\checkmark$ & $\mathrm{C} 2$ & 17 Nov 89 & present \\
\hline & 11 & & $\checkmark$ & & & $\checkmark$ & C5 & 17 Nov 89 & present \\
\hline $\begin{array}{l}\text { Basalt Side } \\
\text { Slope }\end{array}$ & 12 & $\checkmark$ & & $\checkmark$ & & & D2 & 1 Nov 94 & present \\
\hline $\begin{array}{l}\text { Sandy } \\
\text { Gravel Side } \\
\text { Slope }\end{array}$ & 14 & $\checkmark$ & & $\checkmark$ & & & D4 & 1 Nov 94 & present \\
\hline \multirow{4}{*}{$\begin{array}{l}\text { Hanford } \\
\text { Barrier } \\
\text { Erosion / } \\
\text { Dune Sand } \\
\text { Deposition }\end{array}$} & 19 & $\checkmark$ & & & $\checkmark$ & & D5 & 17 Nov 97 & present \\
\hline & & $\checkmark$ & & & $\checkmark$ & & W2 & 17 Nov 97 & present \\
\hline & 20 & & $\checkmark$ & & $\checkmark$ & & D12 & 17 Nov 97 & present \\
\hline & & & $\checkmark$ & & $\checkmark$ & & W4 & 17 Nov 97 & present \\
\hline \multirow{2}{*}{$\begin{array}{l}\text { Sand Dune } \\
\text { Migration }\end{array}$} & 21 & $\checkmark$ & & & $\checkmark$ & & D6 & $22 \mathrm{Jul} 98$ & present \\
\hline & 22 & & $\checkmark$ & & $\checkmark$ & & D8 & 22 Jul 98 & present \\
\hline \multirow{2}{*}{$\begin{array}{l}\text { Modified } \\
\text { RCRA } \\
\text { Subtitle C } \\
\text { Barrier }\end{array}$} & 23 & $\checkmark$ & & & & $\checkmark$ & D7 & 23 Feb 99 & present \\
\hline & 24 & & $\checkmark$ & & & $\checkmark$ & D9 & 23 Feb 99 & Present \\
\hline $\begin{array}{l}\text { (a) Vegetat } \\
\text { vegetati }\end{array}$ & Symbols: & $\mathrm{NV}=$ no $\mathrm{v}$ & etation, S & $=\mathrm{sh}$ & w roc & vege & on and DR & $V=$ Deep rc & \\
\hline
\end{tabular}


Table 5.3. FLTF Treatment Descriptions

\begin{tabular}{|c|c|c|}
\hline Treatment Name & Treatment Description & Lysimeter ID \\
\hline Hanford Barrier & $\begin{array}{l}1.5 \mathrm{~m} \text { of silt loam that rests on a sequence of materials } \\
\text { grading from sand to gravel filter layers and finally to } \\
\text { basalt riprap. }\end{array}$ & $\begin{array}{l}\text { W1, C3, D1, } \\
\text { W3, C6 }\end{array}$ \\
\hline Eroded Hanford Barrier & $\begin{array}{l}\text { Similar to the Hanford Barrier test, with the exception } \\
\text { that the silt loam layer thickness is reduced from } 1.5 \text { to } \\
1.0 \mathrm{~m} \text {. }\end{array}$ & D3, D13 \\
\hline Gravel Mulch & $\begin{array}{l}0.15 \mathrm{~m} \text { of coarse gravel above } 1.35 \mathrm{~m} \text { of screened (to } \\
\text { remove gravel) Pitrun sand, on top of unscreened Pitrun } \\
\text { sand. }\end{array}$ & C1, C4 \\
\hline Pitrun Sand & $\begin{array}{l}1.5 \text { m of screened (to remove gravel) Pitrun sand on top } \\
\text { of unscreened Pitrun sand. }\end{array}$ & C2, C5 \\
\hline Basalt Side Slope & $\begin{array}{l}1.5 \mathrm{~m} \text { of unscreened basalt riprap. Beneath the basalt } \\
\text { layer is a } 0.15-\mathrm{m} \text { thick asphaltic concrete layer underlain } \\
\text { by gravel and more basalt riprap. Resting on top of the } \\
\text { asphaltic concrete is about } 2 \text { to } 3 \mathrm{~cm} \text { of silt loam. }\end{array}$ & D2 \\
\hline Sandy Gravel Side Slope & $\begin{array}{l}1.5 \mathrm{~m} \text { of sandy gravel resting on an asphaltic concrete } \\
\text { layer in a manner similar to the basalt side slope test. }\end{array}$ & D4 \\
\hline $\begin{array}{l}\text { Hanford Barrier Erosion / Dune } \\
\text { Sand Deposition }\end{array}$ & $\begin{array}{l}\text { Similar to the Hanford Barrier test, with the exception } \\
\text { that the top } 20 \mathrm{~cm} \text { of silt loam is removed and replaced } \\
\text { with dune sand. }\end{array}$ & $\begin{array}{l}\text { D5, W2, D12, } \\
\text { W4 }\end{array}$ \\
\hline Sand Dune Migration & $3 \mathrm{~m}$ of dune sand. & D6, D8 \\
\hline Modified RCRA Subtitle C Barrier & $\begin{array}{l}\text { A barrier design with only } 1 \mathrm{~m} \text { of silt loam. In addition, } \\
\text { the silt layer has two modifications: } 1 \text { ) the upper } 0.5 \mathrm{~m} \\
\text { of silt loam is amended with pea gravel at the rate of } \\
15 \% \text { by weight, and } 2 \text { ) the lower } 0.5 \mathrm{~m} \text { of silt is } \\
\text { compacted to create a low-conductivity layer. }\end{array}$ & D7, D9 \\
\hline
\end{tabular}




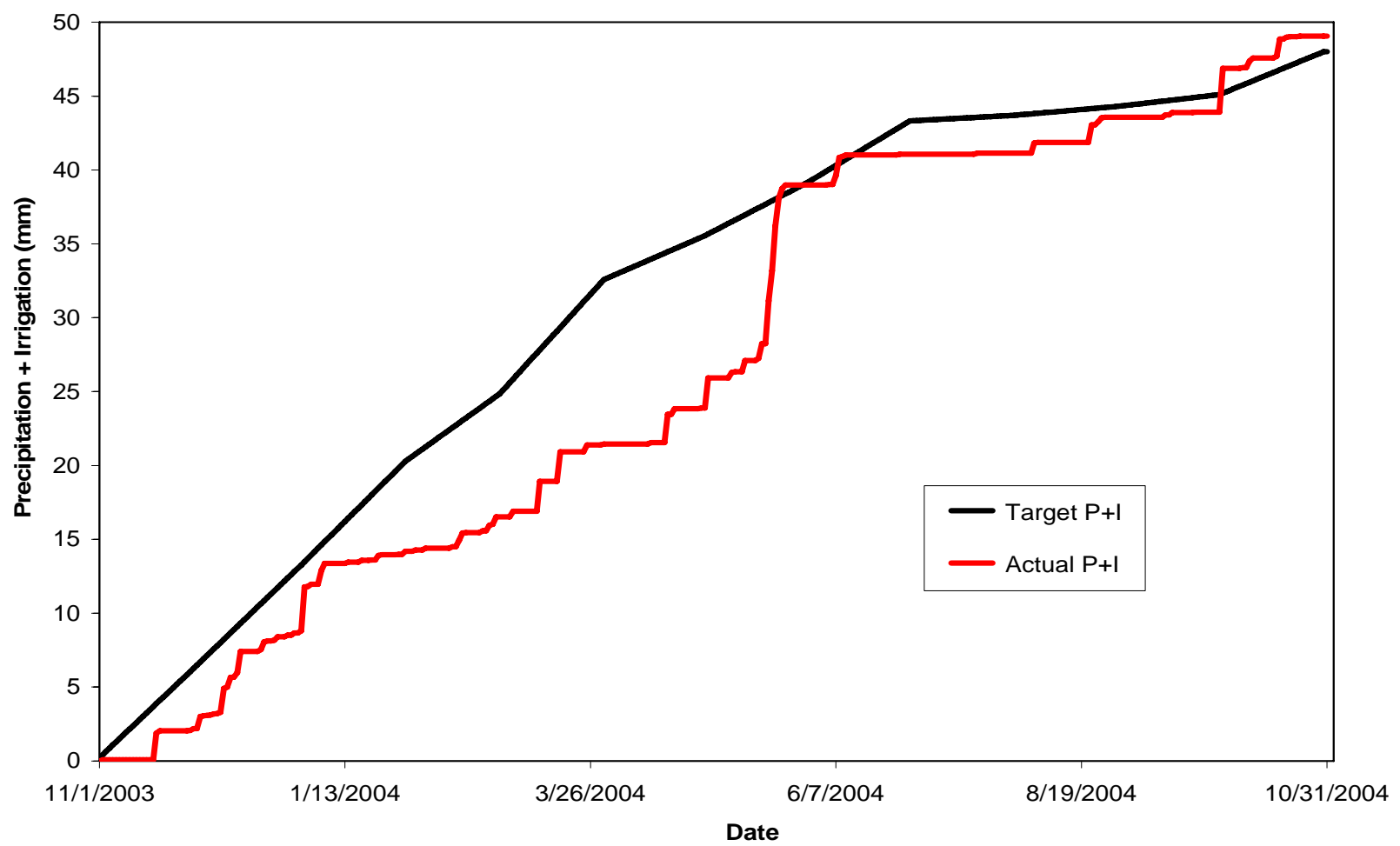

Figure 5.16. FLTF-Precipitation Plus Irrigation Water Year 2004 (11/01/03-10/31/04)

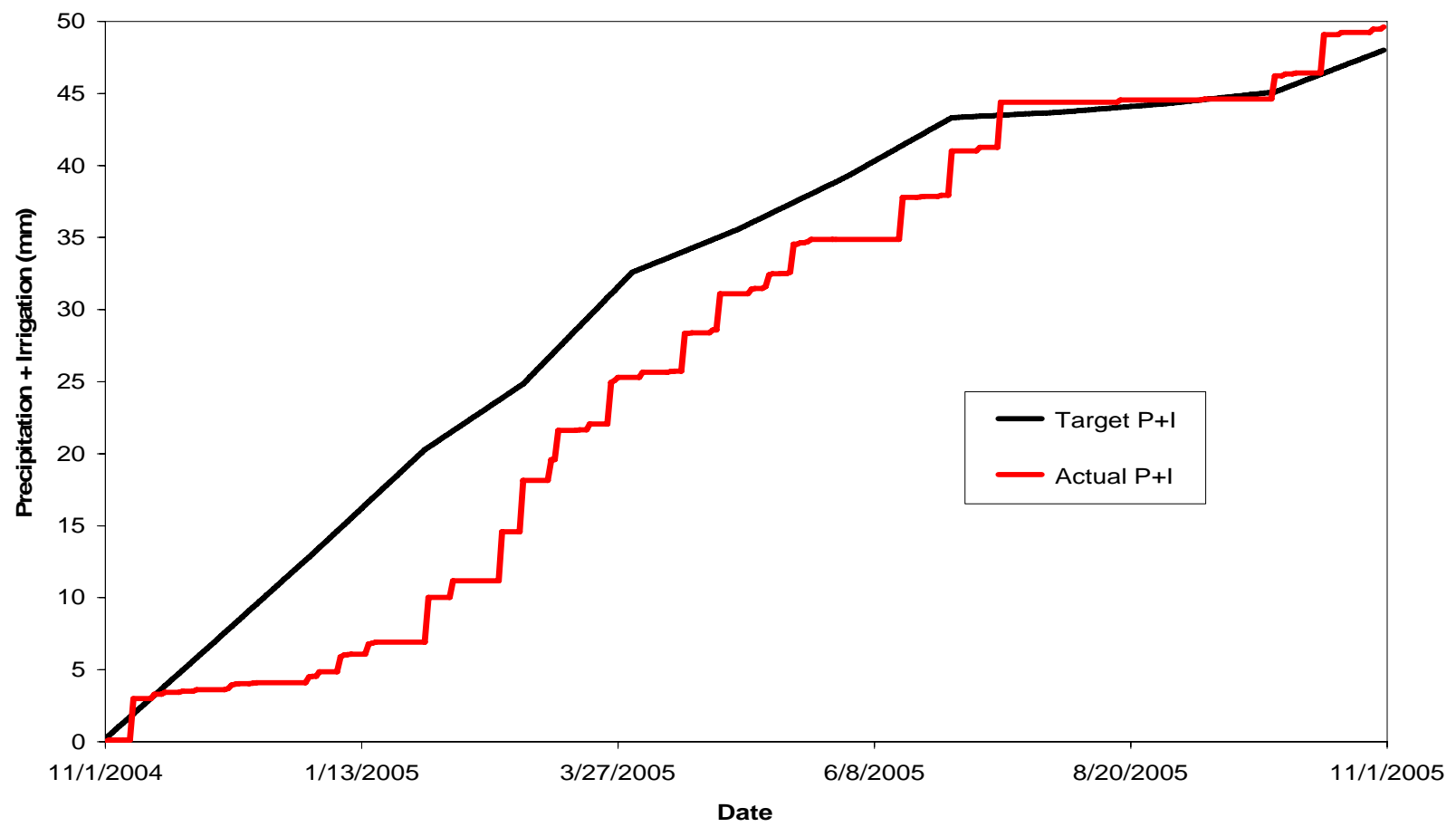

Figure 5.17. FLTF Precipitation Plus Irrigation Water Year 2005 (11/01/04-10/31/05) 


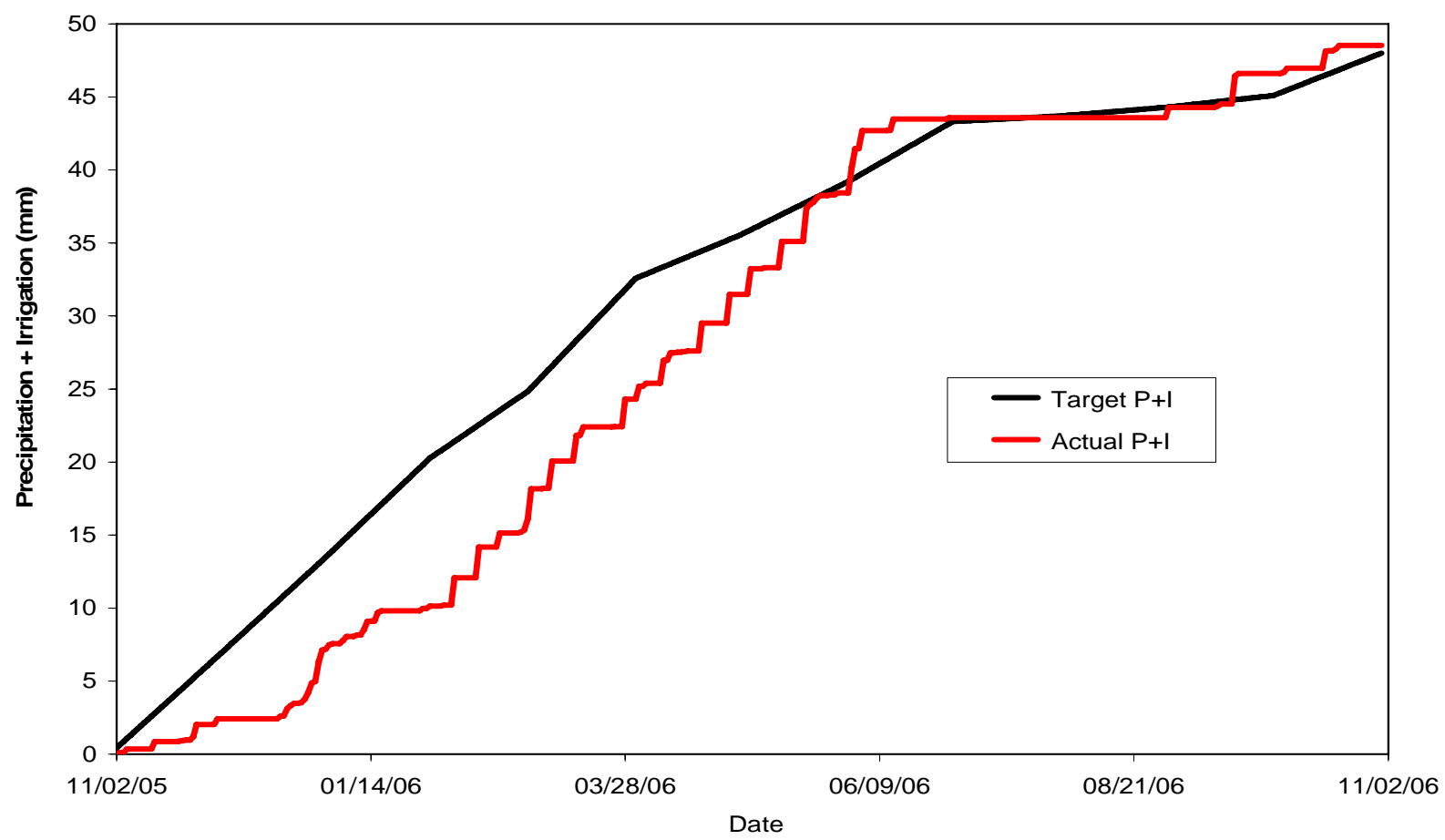

Figure 5.18. FLTF Precipitation Plus Irrigation Water Year 2006 (11/01/05-10/31/06)

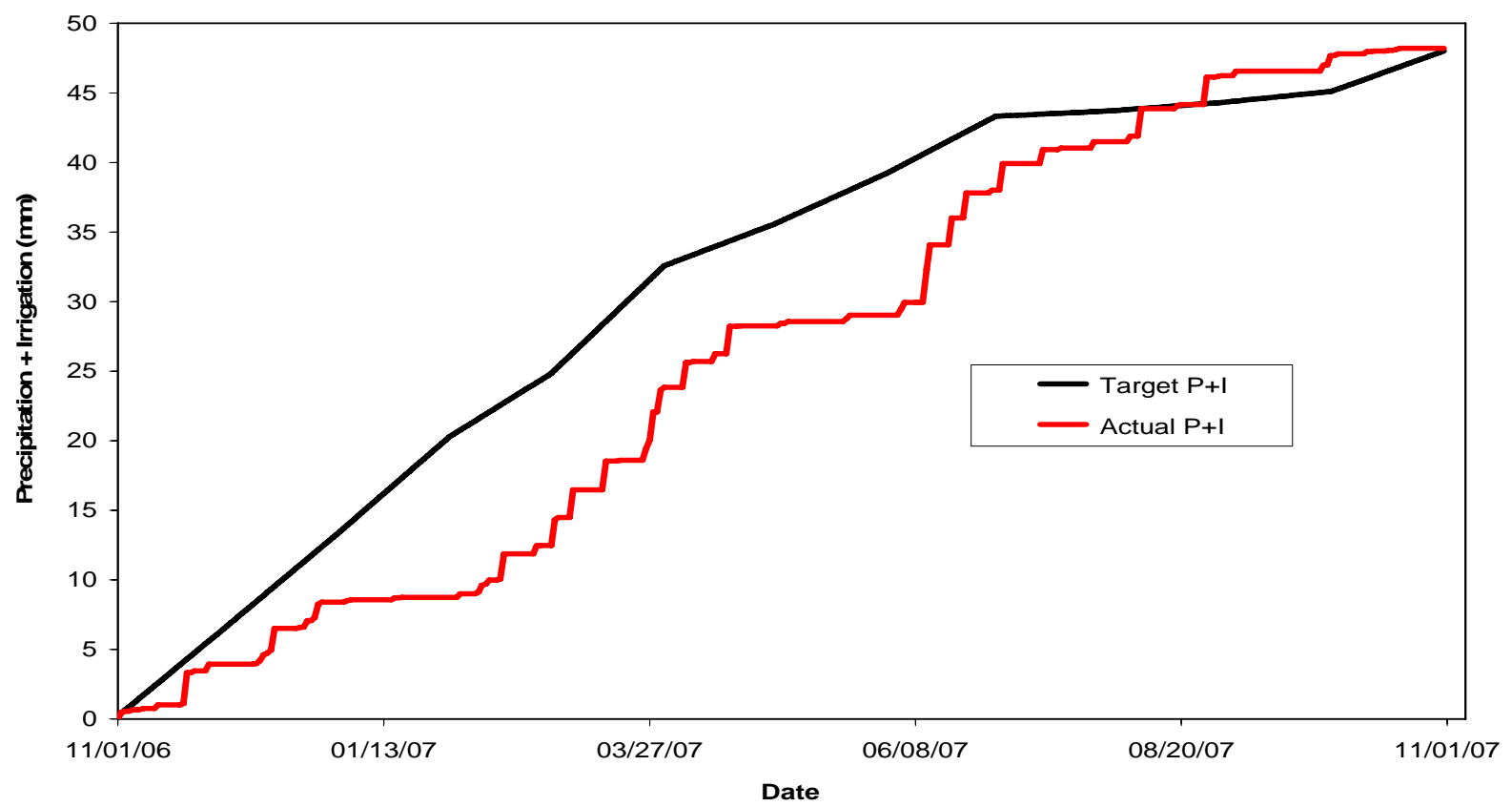

Figure 5.19. FLTF Precipitation Plus Irrigation Water Year 2007 (11/01/06-10/31/07) 


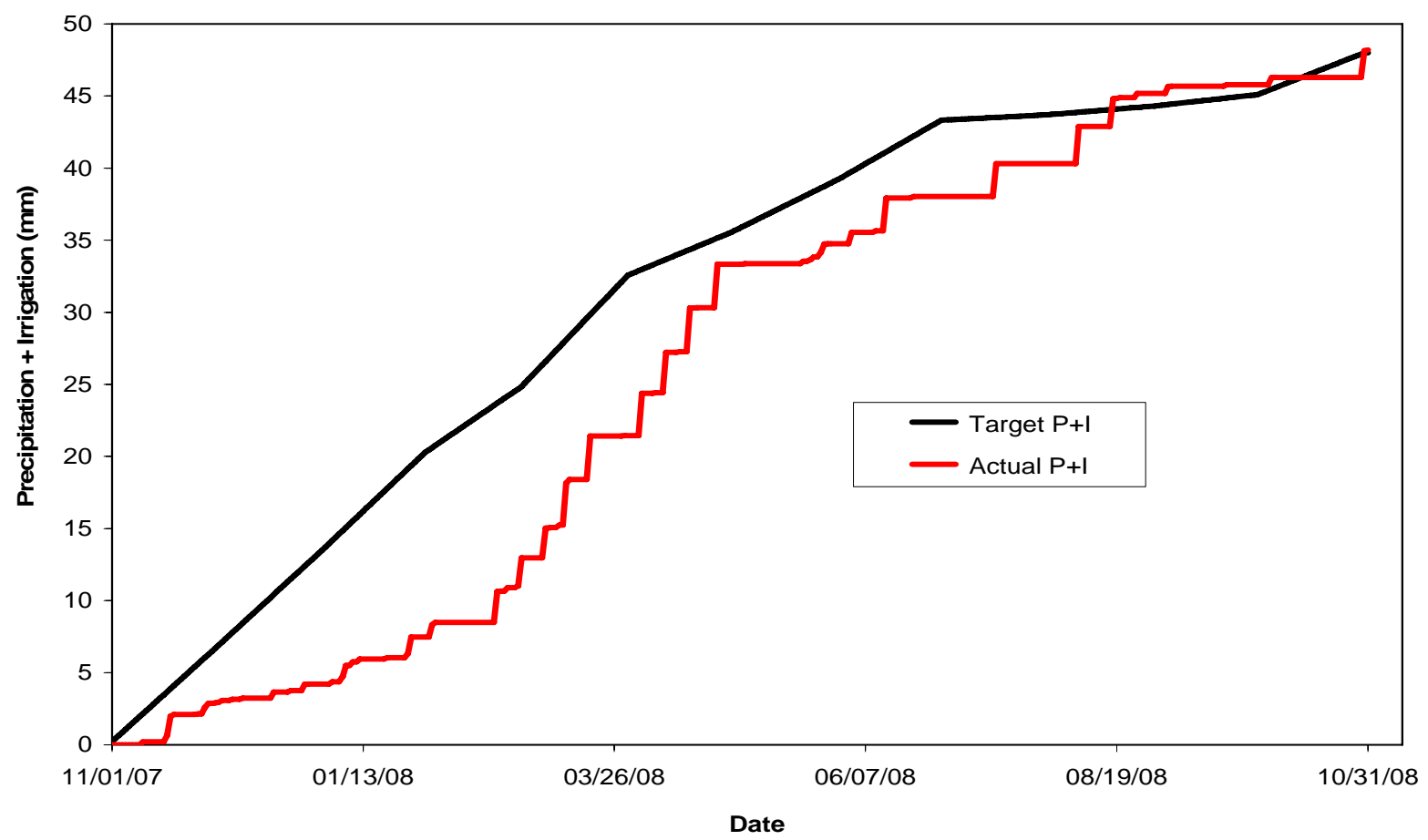

Figure 5.20. FLTF Precipitation Plus Irrigation Water Year 2008 (11/01/07-10/31/08).

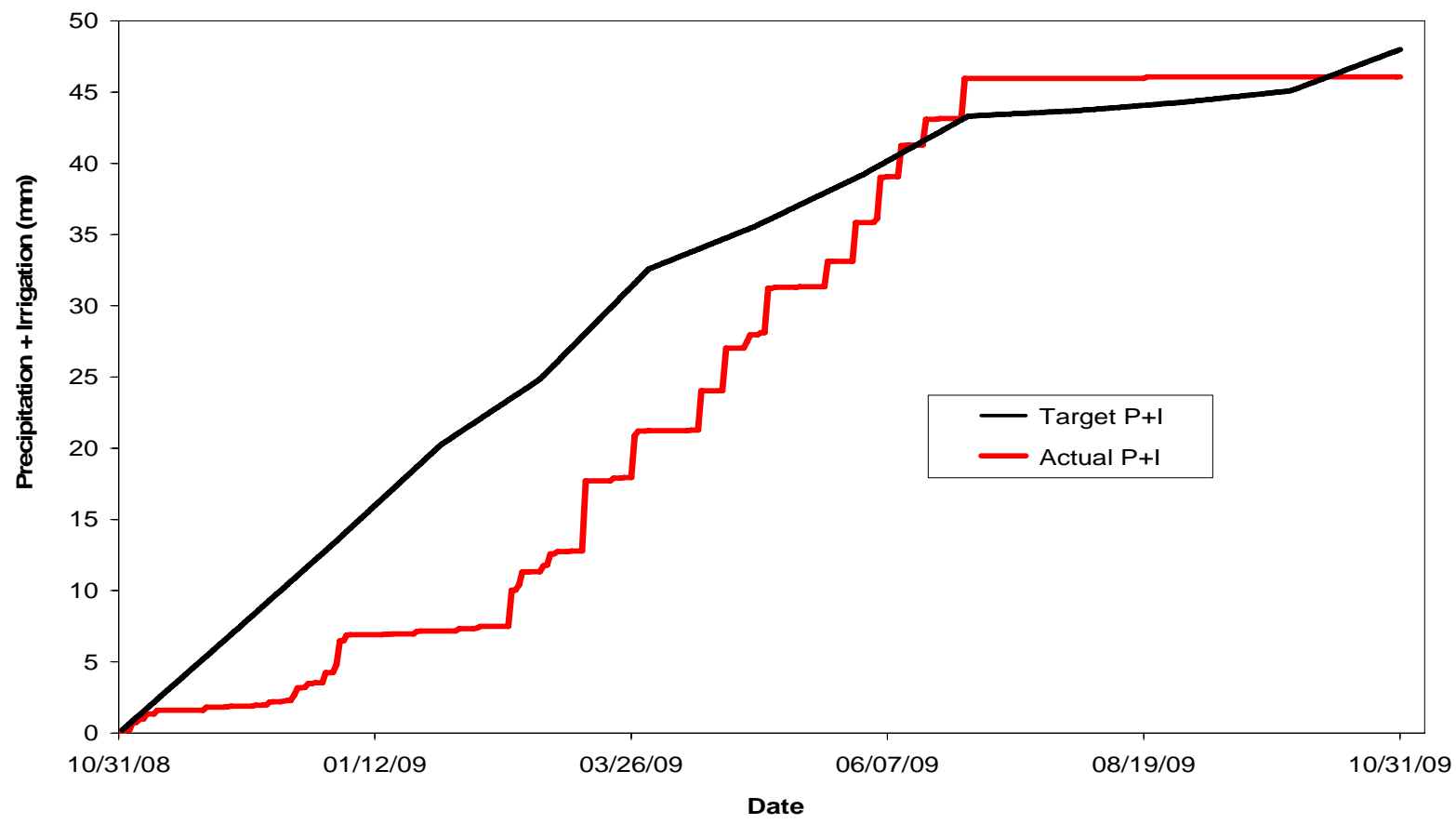

Figure 5.21. FLTF Irrigation Plus Precipitation Water Year 2009 (11/01/08-10/31/09) 
Figure 5.22 shows the cumulative drainage from the Hanford Barrier Erosion/Dune Sand Deposition treatment. Drainage is measured at a rate of $151.6 \mathrm{~mm} / \mathrm{yr}$ under the $3 \mathrm{X}$ precipitation conditions for D12. The same treatment under ambient precipitation conditions (D5) began draining in 2002 and has drained a total of $2.7 \mathrm{~mm}$ for an average drainage rate of $0.2 \mathrm{~mm} / \mathrm{yr}$ calculated since installation $(0.4 \mathrm{~mm} / \mathrm{yr}$ if calculated since drainage onset). Figure 5.23 shows the cumulative drainage from the sand dune migration test. Under enhanced precipitation this treatment produces significant drainage, with a measured drainage rate of $198.2 \mathrm{~mm} / \mathrm{yr}$. The D6 lysimeter (ambient precipitation) did not begin draining until 2004, but has drained steadily since that time for an average drainage rate of $21.9 \mathrm{~mm} / \mathrm{yr}$ calculated since installation ( $38.2 \mathrm{~mm} / \mathrm{yr}$ if calculated since drainage onset). Figure 5.24 shows the cumulative drainage for the sandy gravel (D4) and basalt side slope (D2) treatments under ambient precipitation conditions. Both lysimeters have consistently drained at significant rates since monitoring of these treatments began, with drainage rates of $41.0 \mathrm{~mm} / \mathrm{yr}$ for the basalt treatment and $94.6 \mathrm{~mm} / \mathrm{yr}$ for the sand gravel treatment. Figure 5.25 shows the cumulative drainage for the eroded Hanford Barrier treatment. Drainage from this lysimeter didn't begin until 2003, but has continually drained since, although at decreasing rates every year. Figure 5.26 shows cumulative drainage from the gravel mulch and pit run sand treatments under ambient and enhanced precipitation. Both treatments continued to have significant drainage in 2009. A summary of average drainage rates for each treatment as of September 14, 2007 is presented in Table 3.

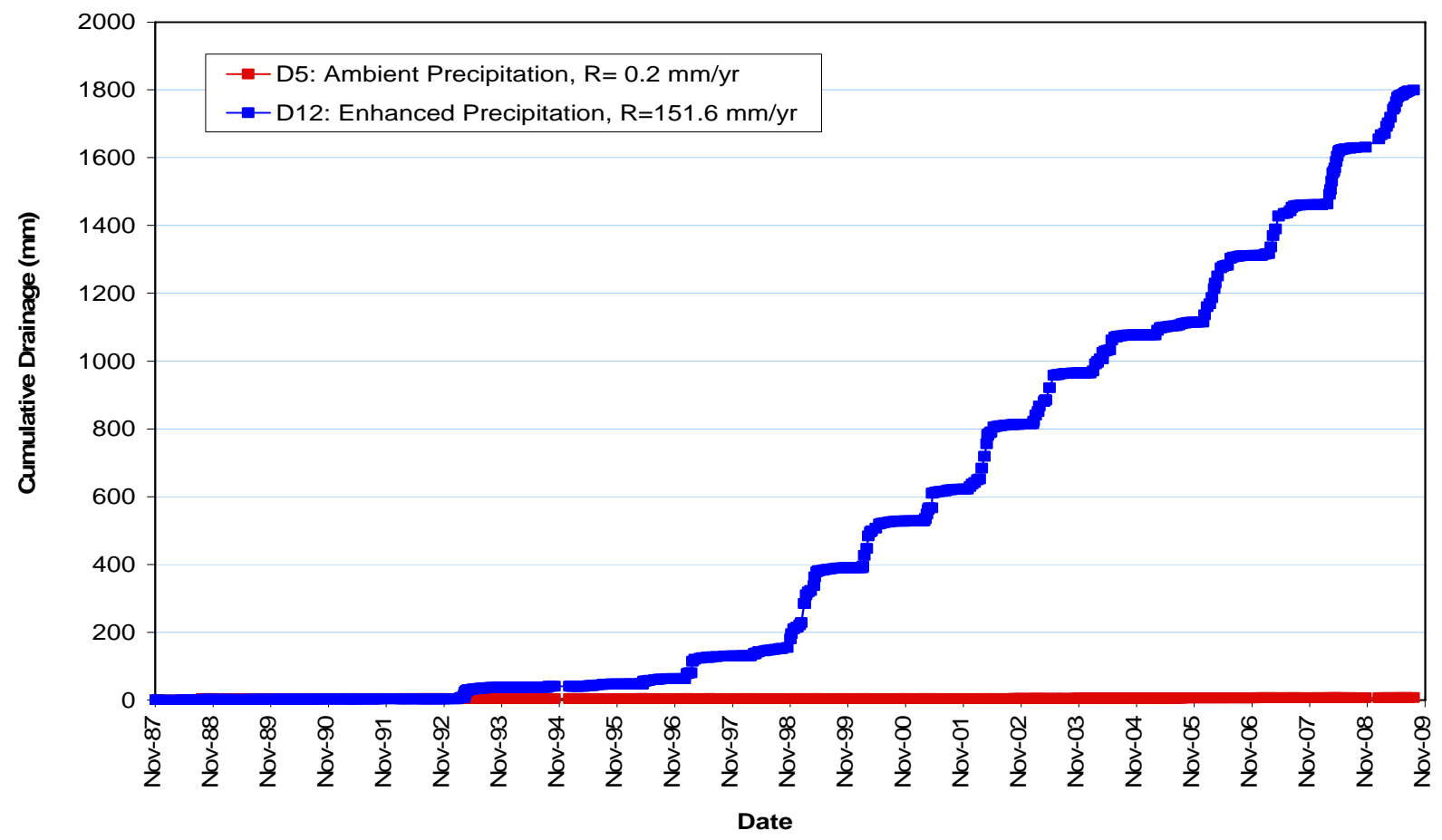

Figure 5.22. FLTF Cumulative Drainage for FLTF Treatments D5 and D12 Representing a Hanford Barrier Dune Sand Deposition Test (Shallow Rooted Vegetation). R is the mean annual drainage rate. 


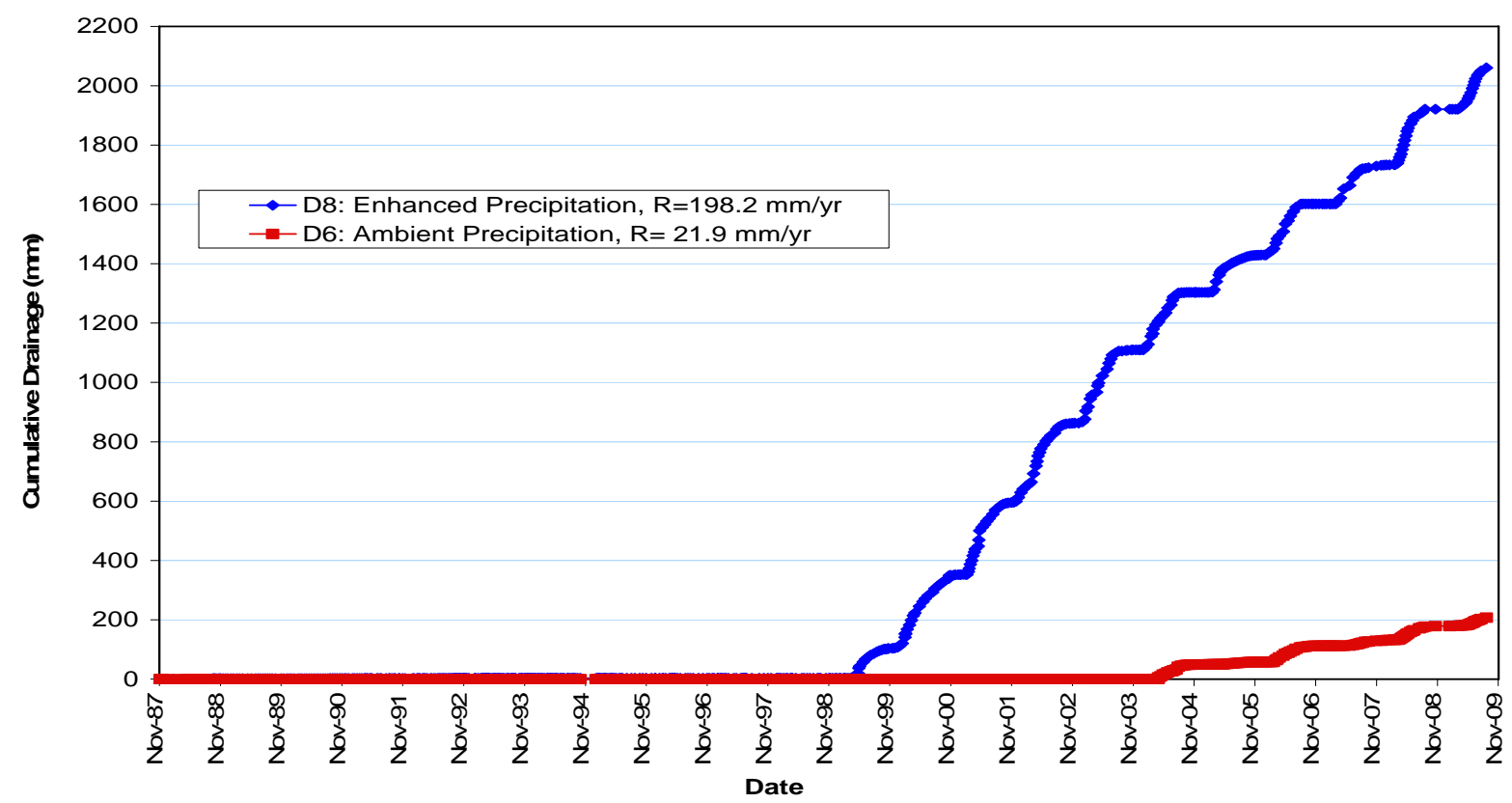

Figure 5.23. Cumulative Drainage for FLTF Treatments D6 and D8 Representing a Sand Dune Migration Test (Shallow Rooted Vegetation). $\mathrm{R}$ is mean annual drainage rate.

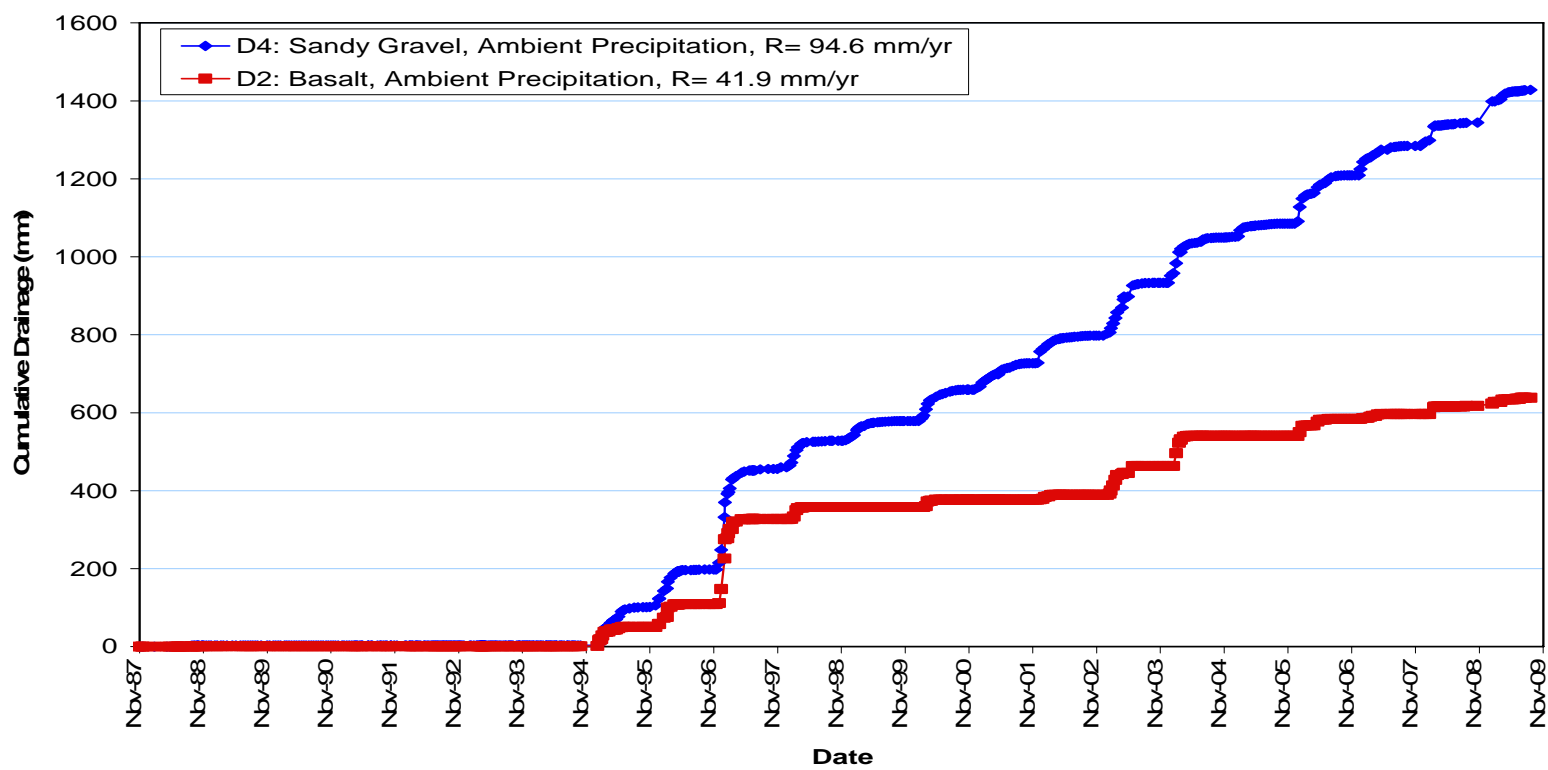

Figure 5.24. Cumulative Drainage for FLTF Treatments D2 and D4 Representing a Barrier Side Slope Test. $\mathrm{R}$ is the mean annual drainage rate. 


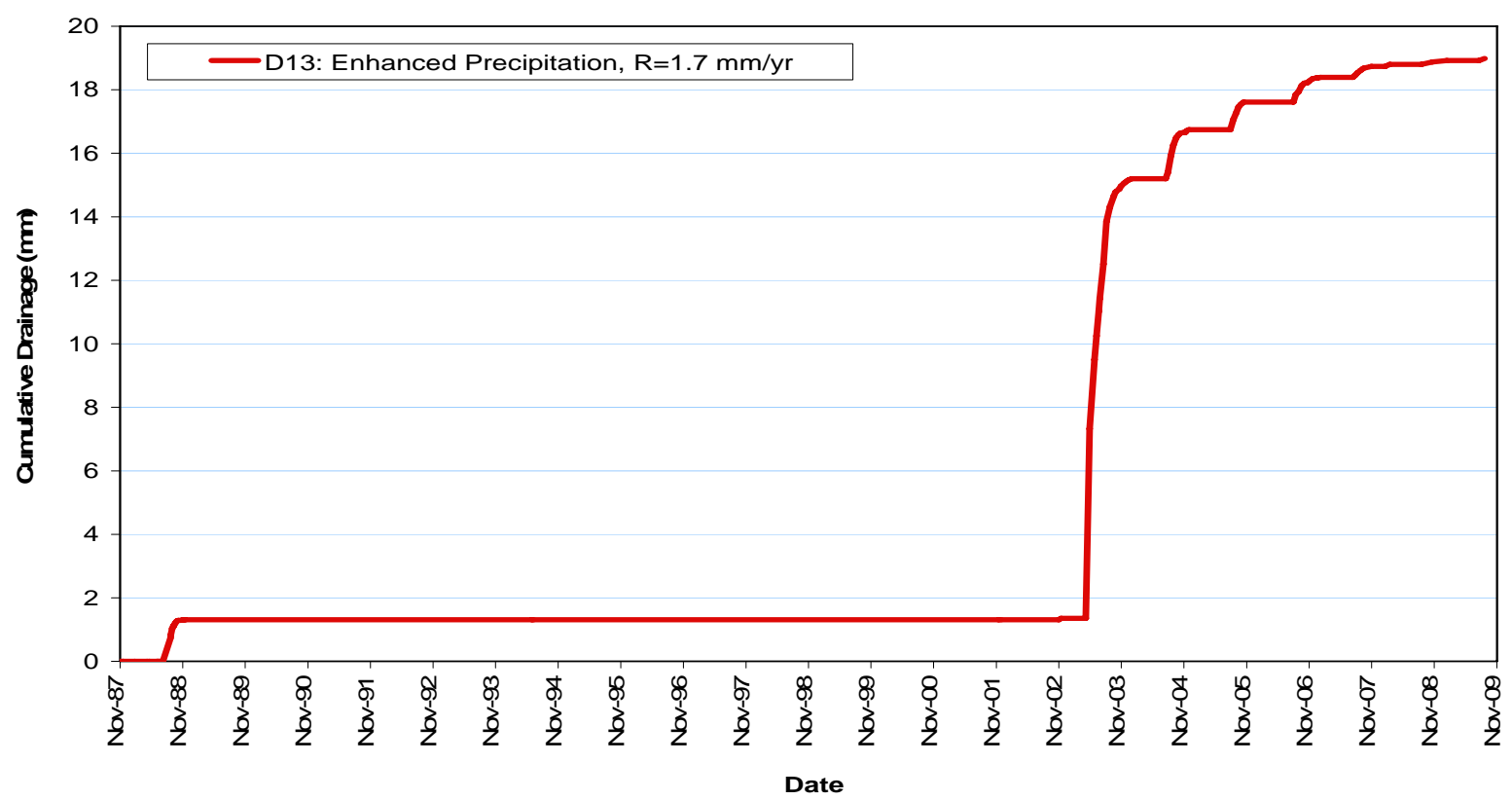

Figure 5.25. Cumulative Drainage for FLTF Treatment D13 Representing an Eroded Prototype Hanford Barrier Test. $\mathrm{R}$ is the mean annual drainage rate.

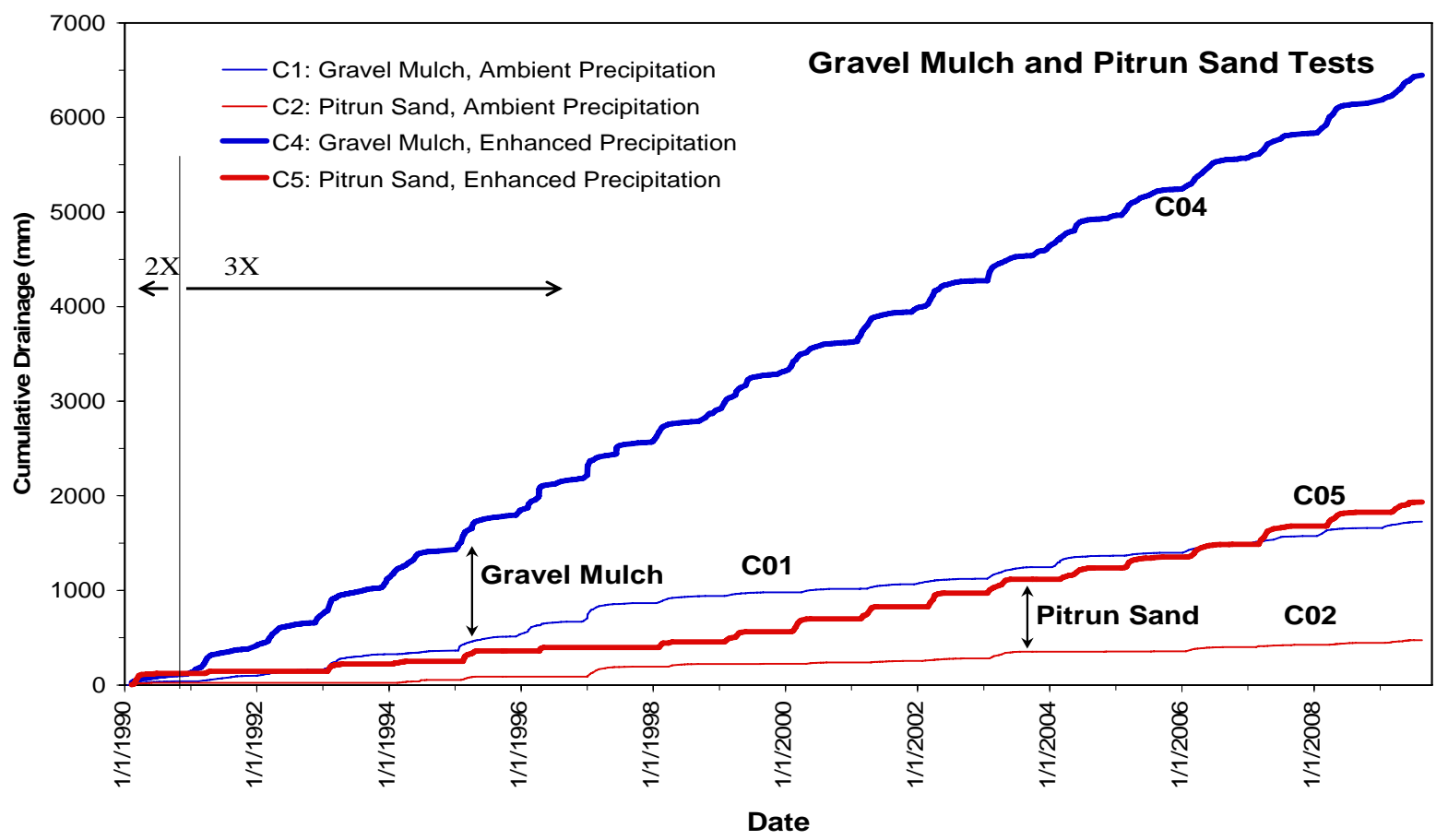

Figure 5.26. Cumulative Drainage for FLTF Treatments C1, C2, C4, and C5. 
Table 5.4. Summary of FLTF Drainage Rates Though August 20th, 2009

\begin{tabular}{|c|c|c|c|c|c|}
\hline \multirow[b]{2}{*}{ Test Description } & \multirow[b]{2}{*}{$\begin{array}{l}\text { Lysimeter } \\
\text { ID }\end{array}$} & \multirow[b]{2}{*}{$\begin{array}{l}\text { Precipitation } \\
\text { Treatment }\end{array}$} & \multirow[b]{2}{*}{$\begin{array}{l}\text { Monitoring } \\
\text { Period } \\
\text { Start }\end{array}$} & \multicolumn{2}{|c|}{ Drainage Rate $(\mathrm{mm} / \mathrm{yr})^{(\mathrm{a})}$} \\
\hline & & & & $\begin{array}{l}\text { Installation } \\
\text { Basis }\end{array}$ & $\begin{array}{c}\text { Drainage } \\
\text { Onset } \\
\text { Basis }\end{array}$ \\
\hline Hanford Barrier & D1 & Ambient & 4-Nov-1987 & 0.00 & NA \\
\hline \multirow[t]{2}{*}{ Eroded Hanford Barrier } & D3 & Ambient & 4-Nov-1987 & 0.00 & NA \\
\hline & D13 & Ambient & 27-May-1998 & 1.70 & 2.6 \\
\hline \multirow[t]{2}{*}{ Gravel Mulch } & $\mathrm{C} 1$ & Ambient & 17-Nov-1989 & 86.9 & 87.6 \\
\hline & C4 & Enhanced & 17-Nov-1989 & 324.8 & 58.5 \\
\hline \multirow[t]{2}{*}{ Pitrun Sand } & $\mathrm{C} 2$ & Ambient & 17-Nov-1989 & 23.5 & 4.2 \\
\hline & C5 & Enhanced & 17-Nov-1989 & 97.8 & 17.6 \\
\hline Basalt Side Slope & D2 & Ambient & 1-Nov-1994 & 41.9 & 41.9 \\
\hline Sandy Gravel Side Slope & D4 & Ambient & 1-Nov-1994 & 94.6 & 94.6 \\
\hline \multirow{3}{*}{$\begin{array}{l}\text { Hanford Barrier Erosion / Dune } \\
\text { Sand Deposition }\end{array}$} & D5 & Ambient & 17-Nov-1997 & 0.20 & 0.20 \\
\hline & D12 & Enhanced & 17-Nov-1997 & 151.6 & 151.6 \\
\hline & W4 & Enhanced & 17-Nov-1997 & 66.7 & 66.7 \\
\hline \multirow[t]{2}{*}{ Sand Dune Migration } & D6 & Ambient & 22-Jul-1998 & 21.9 & 38.2 \\
\hline & D8 & Enhanced & 22-Jul-1998 & 198.2 & 198.2 \\
\hline \multirow{2}{*}{$\begin{array}{l}\text { Modified RCRA SubtitleC } \\
\text { Barrier }\end{array}$} & D7 & Ambient & 23-Feb-1999 & 0.00 & \\
\hline & D9 & Enhanced & 23-Feb-1999 & 0.00 & \\
\hline
\end{tabular}

(a) All drainage rates reported to three significant figures.

The drainage rate is calculated for two bases: first calculating the average annual drainage rate on the basis of time since installation, and second calculating the average annual drainage rate on the basis of time since drainage onset. A newly installed lysimeter requires some time to stabilize and begin to drain at a long-term average rate, so including the time required to reach a long-term moisture profile may not provide the best basis for estimating an annual average drainage rate; hence the reason for the second basis. A lysimeter experiencing higher precipitation (such as for the enhanced precipitation treatments) will stabilize faster, so in those cases the drainage rates calculated under both bases do not differ much or at all. For ambient conditions in less conductive soils, stabilization of the moisture profile takes longer and the difference can be substantial.

Figure 5.27 shows the change in water storage since October 1, 2004 for W1 and W3, as calculated from the weighing lysimeter measurements of mass. As to be expected, water storage increases during the winter and decreases to a minimum in late summer, with a greater change in water storage under enhanced precipitation conditions. 


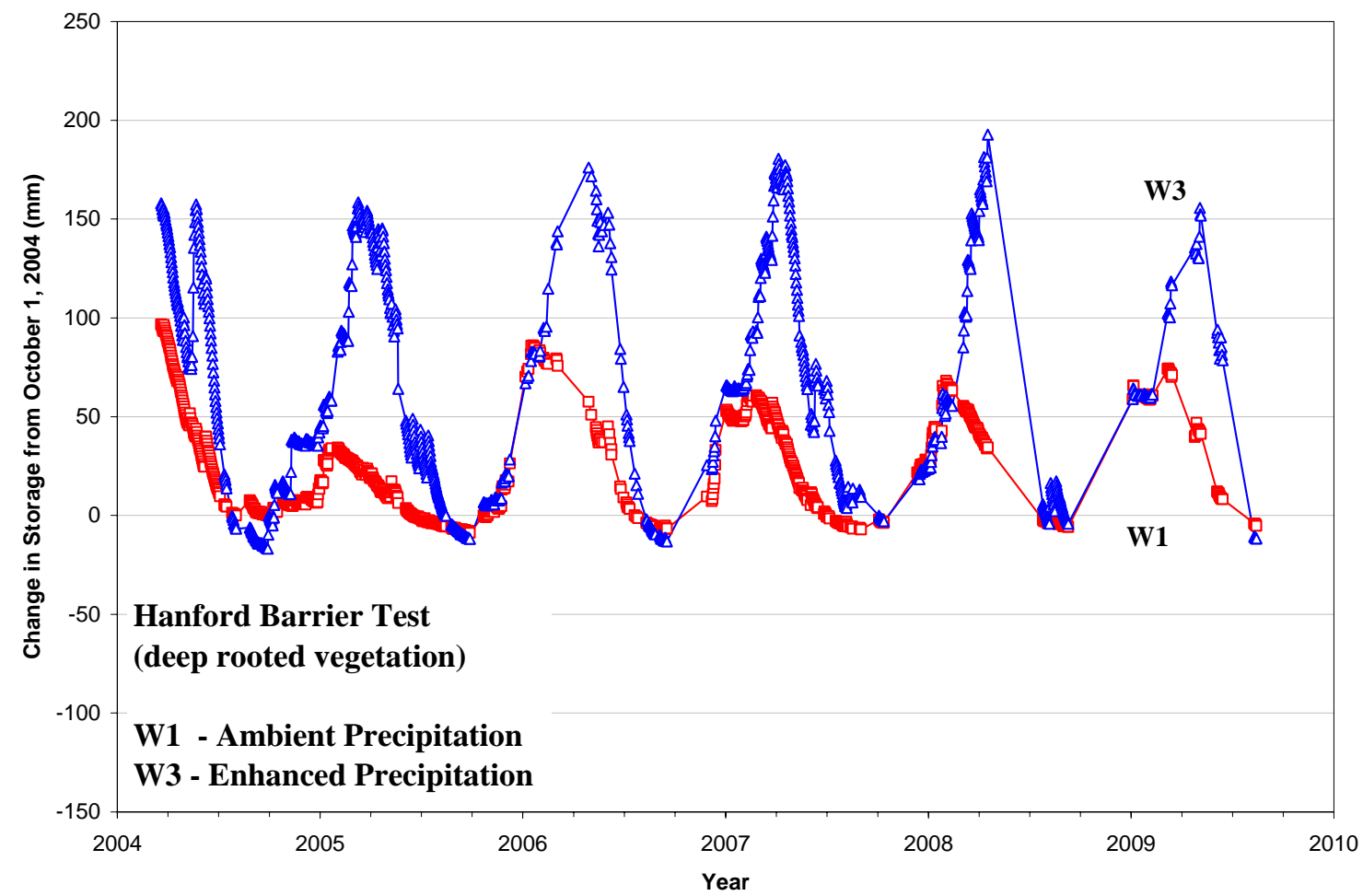

Figure 5.27. Changes in water storage (in equivalent water depth, $\mathrm{mm}$ ) for weighing lysimeters $\mathrm{W} 1$ and W3 at the FLTF.

The scale for W4 was replaced in late 2006. During FY 2007 weighing lysimeters W2 and W4 both responded uncharacteristically. Just after it was installed and calibrated (mid-January 2007), W4 appeared to experience a bind that went unnoticed until late in 2007. Intervention in the form of prying on the scale between the sediment-filled lysimeter box and its enclosure appeared to alleviate the problem at least temporarily.

The CR7 datalogger that records measurements from the weighing lysimeters has been working intermittently for the past 3-4 years resulting in numerous periods without data. This datalogger was slated for replacement in FY 2008 but several issues were identified with using the replacement datalogger, a CR1000 model: the CR7 was determined to be better suited for use with the scales at FLTF. The CR1000 would appear to require voltage amplifiers be built in order to achieve the same precision as the CR7. The lack of wiring diagrams for this old system that includes numerous thermocouples connected to the CR7 datalogger has also hindered such an upgrade. Before commencing such an upgrade, the use and value of the data collected from the weighing lysimeters and thermocouples needs to be reviewed. During FY08 the control module of the CR7 datalogger at FLTF was replaced with one from another CR7 datalogger that was no longer in use. These changes do not appear to have corrected the problems.

During FY2008 lysimeters W2 and W4 continued to respond uncharacteristically. The weighing lysimeter scales were calibrated again in September 2008. The scale readings for W4 in particular were hysteretic, which lead the technician who calibrated the scales to speculate that the scale for W4 has a bad 
load cell. Lysimeters W2 and W4 continue to exhibit uncharacteristic behavior so the data from these lysimeters is not shown here.

At some point a decision should be made about what to do with these two weighing lysimeters (W2 and W4) and the datalogger at FLTF. Drainage from the bottom of the various lysimeters at the FLTF is the key variable of interest, so measuring the changes in water storage recorded by the weighing lysimeters is not considered to be absolutely critical. Nevertheless, changes in water storage represent one component of the soil water balance equation so if these data were reliable they would be very useful for relative comparison, and for validation of numerical models that include the processes of evapotranspiration and root-water update.

Matric potential data for the D12 and W4 lysimeters at $100 \mathrm{~cm}$ and $150 \mathrm{~cm}$ depths are shown in Figures 5.28 and 5.29, respectively. These data exhibit typical seasonal variation, with drying in the summer (more negative matric potentials) and wetting in the winter (less negative matric potentials). At times the matric potential measurements in the W4 lysimeter is positive, likely because saturated conditions in the lysimeter occurred between drainage measurements. Matric potentials within the sand dune migration treatment lysimeters also display typical season variation (Figure 5.30). Measured water potentials for the ambient D6 lysimeter and enhanced precipitation D8 lysimeter are generally comparable.

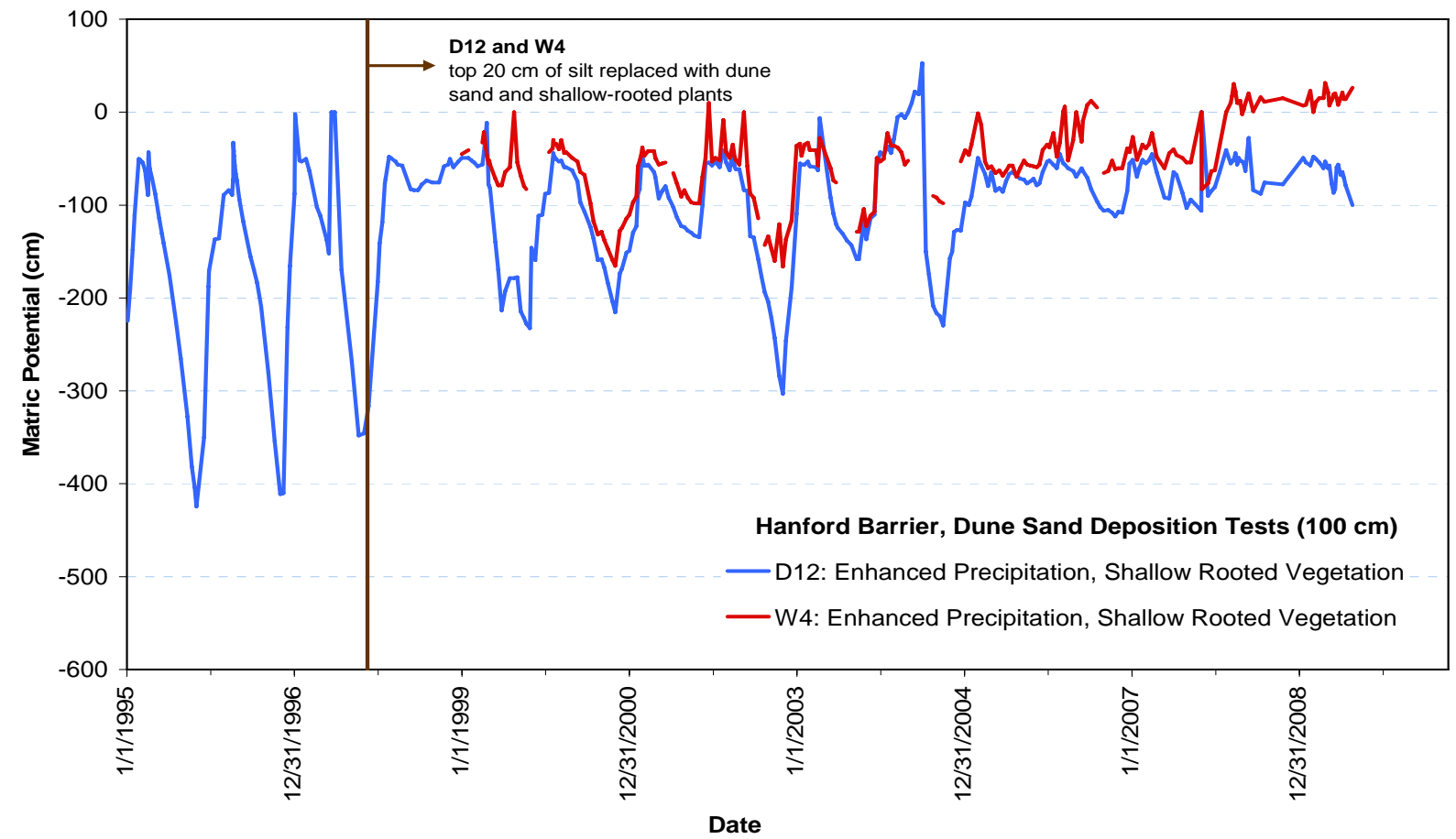

Figure 5.28. FLTF Matric Potentials for Hanford Barrier Erosion/Dune Sand Deposition Test at $100 \mathrm{~cm}$ Depth. 


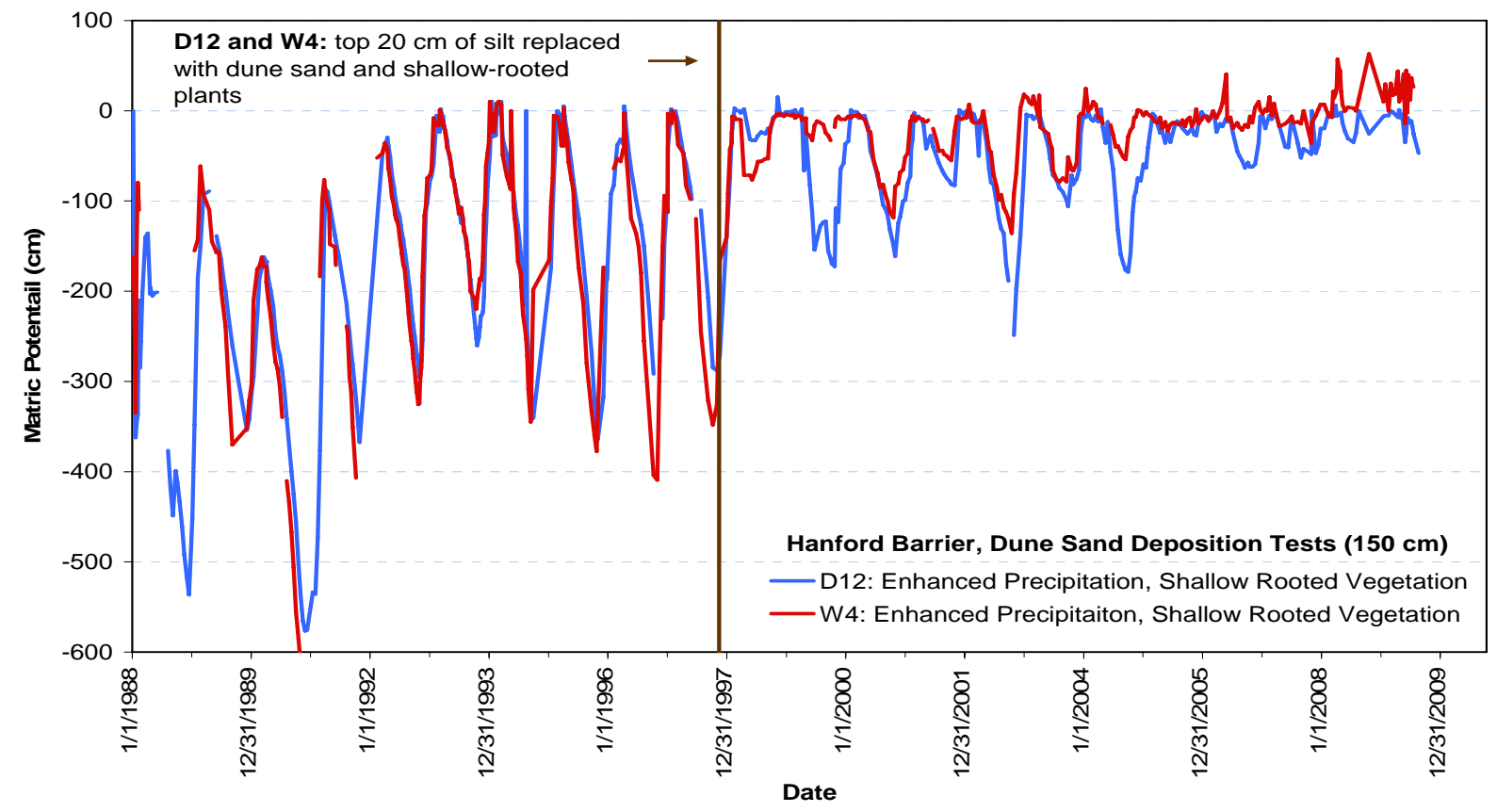

Figure 5.29. FLTF Matric Potentials for Hanford Barrier Erosion/Dune Sand Deposition Test at $150 \mathrm{~cm}$ Depth.

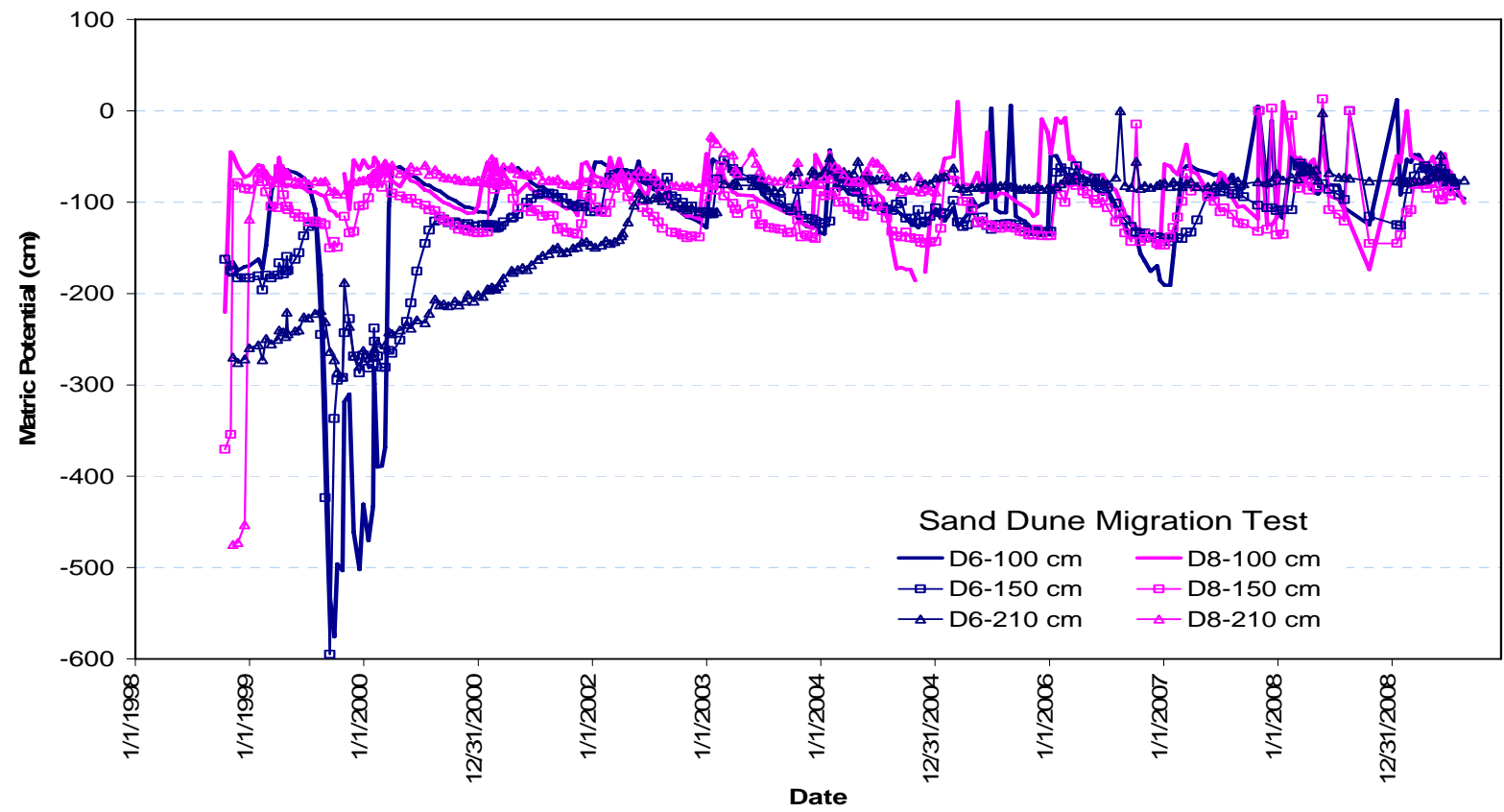

Figure 5.30. FLTF Matric Potentials for Sand Dune Migration Test (100, 150, and $210 \mathrm{~cm}$ Depths).

Efforts were begun in FY 2007 to use chloride concentrations in drainage water from FLTF lysimeters to capture the modern atmospheric chloride deposition rate. The atmospheric chloride deposition rate is important because it is a critical parameter in the calculation of recharge using the chloride mass balance method. The first round of measurements was made in September 2007 and 
measurements have since been taken in September of 2008 and June of 2009. Drainage water was collected from each Lysimeter in high-density polyethylene bottles and taken to the Applied Geology and Geochemistry lab for analysis using ion chromatography. Table 5.5 presents the chloride concentration results. Drainage samples were collected in late June this year, and during September in previous years. Therefore more of the lysimeters were actively draining this year and hence more samples were analyzed for chloride. Of the three lysimeters that were sampled in all three years (C1, D4, and D6), C1 and D4 show relatively low (1.23-2.87 $\mathrm{mg} \mathrm{L}^{-1}$ ) and stable concentrations, while D6 shows high, but declining concentrations (254, 88.9, $\left.67.7 \mathrm{mg} \mathrm{L}^{-1}\right)$. D2 also showed a relatively high concentration (48.2 $\mathrm{mg} \mathrm{L}^{-1}$ ), but all of the other lysimeters had concentrations $<4 \mathrm{mg} \mathrm{L}^{-1}$. The reasons why D2 and D6 have higher concentrations are currently unknown but may be related to the source materials. Both of these lysimeters have ambient precipitation (no irrigation).

Previous studies using ${ }^{36} \mathrm{Cl} / \mathrm{Cl}$ ratios measurements in the soil (Murphy et al. 1996, Prych 1998, Fayer et al. 1999) have estimated Hanford chloride deposition rates ranging from 33 to $40 \mathrm{mg} / \mathrm{m}^{2} / \mathrm{yr}$. One possible explanation for the discrepancy is that geochemical conditions within the lysimeters may not be in equilibrium (as assumed). In particular, the high chloride from D6 may reflect residual chloride being flushed from the sediment. Interestingly, at the 300N Lysimeter Site (Gee et al. 2005) also measured drainage water chloride concentrations that were greater than expected given the documented drainage rate of the lysimeter. In that instance, a 22 percent increase in $q_{c l}$ was required in order for the CMB estimated drainage to match the lysimeter drainage record. The analysis of chloride in drainage water from the FLTF is preliminary and thus inconclusive. Additional drainage water samples will be collected and analyzed for chloride concentrations in the coming years to help resolve this issue of apparent chloride deposition rate variability and uncertainty.

Table 5.5. Chloride Concentrations Measured in FLTF Lysimeter Drainage Waters.

\begin{tabular}{cccc}
\hline Lysimeter & \multicolumn{3}{c}{ Chloride Concentation $\left(\mathrm{mg} \mathrm{L}^{-1}\right)$} \\
\cline { 2 - 4 } ID & Sept. 14, 2007 & Sept. 2, 2008 & June 29, 2009 \\
\hline C1 & 2.87 & 2.43 & 2.20 \\
C2 & 5.39 & 7.82 & --- \\
C4 & --- & --- & 2.00 \\
C5 & --- & --- & 3.92 \\
D2 & --- & -- & 48.20 \\
D4 & 1.23 & 1.36 & 1.35 \\
D6 & 254.06 & 88.90 & 67.70 \\
D8 & --- & --- & 1.87 \\
D12 & --- & --- & 1.70 \\
W4 & --- & --- & 2.88 \\
\hline
\end{tabular}

\subsection{Field Lysimeter Test Facility (FLTF) Pit}

The FLTF Pit site is a collection of four cement caissons containing WFMs packed with different soil types adjacent to the FLTF. The FLTF Pit flux meters, their treatments, monitoring periods, and average drainage rates are presented in Table 5.6. The gravel soil is similar to the gravel material in the FLTF D4 lysimeter (Sandy Gravel Side Slope Test). The silt loam soil is from the same source as that used in the FLTF Hanford Barrier treatments. The sand soil is similar to the FLTF Dune Sand Migration test (D6 and D8 lysimeters) soil. The 5/8-inch minus material is similar to the commercial road base material existing on the surfaces of many Hanford tank farms. All WFMs have the divergence columns at the soil 
surface, with the exception of one silt loam WFM that has the divergence column at $1 \mathrm{~m}$ below the soil surface.

A plot of WFM measured drainage for the sand and sandy gravel material and silt loam at two depths is shown in Figure 5.31. Both silt loam WFMs continue to experience no measurable drainage since 2003. The sand and sandy gravel WFMs readily drain, although the sandy gravel filled WFM has stopped functioning, as displayed by its lack of drainage response when the sand WFM is draining. Only a trace of drainage was measured from the sand WFM in 2009. The road base WFMs and sand/silt loam WFM drainage data are depicted in Figure 5.32. Data from the first quarter of 2005 are a bit suspect, with greater drainage expected from the road base only material relative to the sand/silt loam material. Trouble encountered with data collection and functionality of these three WFMs upon installation and into the first quarter of 2005 may have led to this discrepancy. From January of 2006 to present all three of these WFMs appear to be working properly, with measurable drainage in 2006 and 2007. Note that that average drainage rates reported in Table 5.6 are calculated using data from January 2006 through August 2009. As expected, based on material properties, the road base material WFM has the greatest drainage of WFMs 5, 6, and 6. Addition of silt loam to both the sand and road base material results in an increase in the storage capacity of the soil and reduced drainage.

A general comment about the water flux meters is warranted. In some cases, the WFMs appear to provide reliable data but overall their track record at the Hanford field water balance monitoring sites has not been good. Most of the time, poor performance has been attributed to problems with installation and disturbance of the soil profile such that capillary breaks are created. Therefore we recommend that the WFM data be used with caution. Long-term drainage rates measured from the lysimeter facilities are considered to be much more reliable.

Table 5.6. FLTF Pit WFM Treatments, Monitoring Periods, and Average Drainage Rates (Jan 2006 present). All WFM surfaces in the FLTF pit are unvegetated.

\begin{tabular}{clcc}
\hline $\begin{array}{c}\text { Water Flux } \\
\text { Meter ID }\end{array}$ & \multicolumn{1}{c}{ Soil Description } & Monitoring Period & $\begin{array}{c}\text { Average Drainage } \\
\text { Rate }\left(\mathrm{mm} \mathrm{yr}^{-1}\right)\end{array}$ \\
\hline 1 & Sandy Gravel & Nov 2001 - present & 49.3 \\
2 & Silt Loam & Nov 2001 - present & 0 \\
\hline 3 & Silt Loam (1 m) & Nov 2001 - present & 0 \\
4 & Sand & Nov 2001 - present & 34.3 \\
5 & 80\% Sand, 20\% Silt Loam (wt \%) & Jun 2004 - present & 10.9 \\
6 & 5/8-in minus material & Jun 2004 - present & 21.9 \\
7 & 80\% 5/8-inch minus material & Jun 2004 - present & 11 \\
& 20\% Silt Loam (wt\%) & & \\
\hline
\end{tabular}




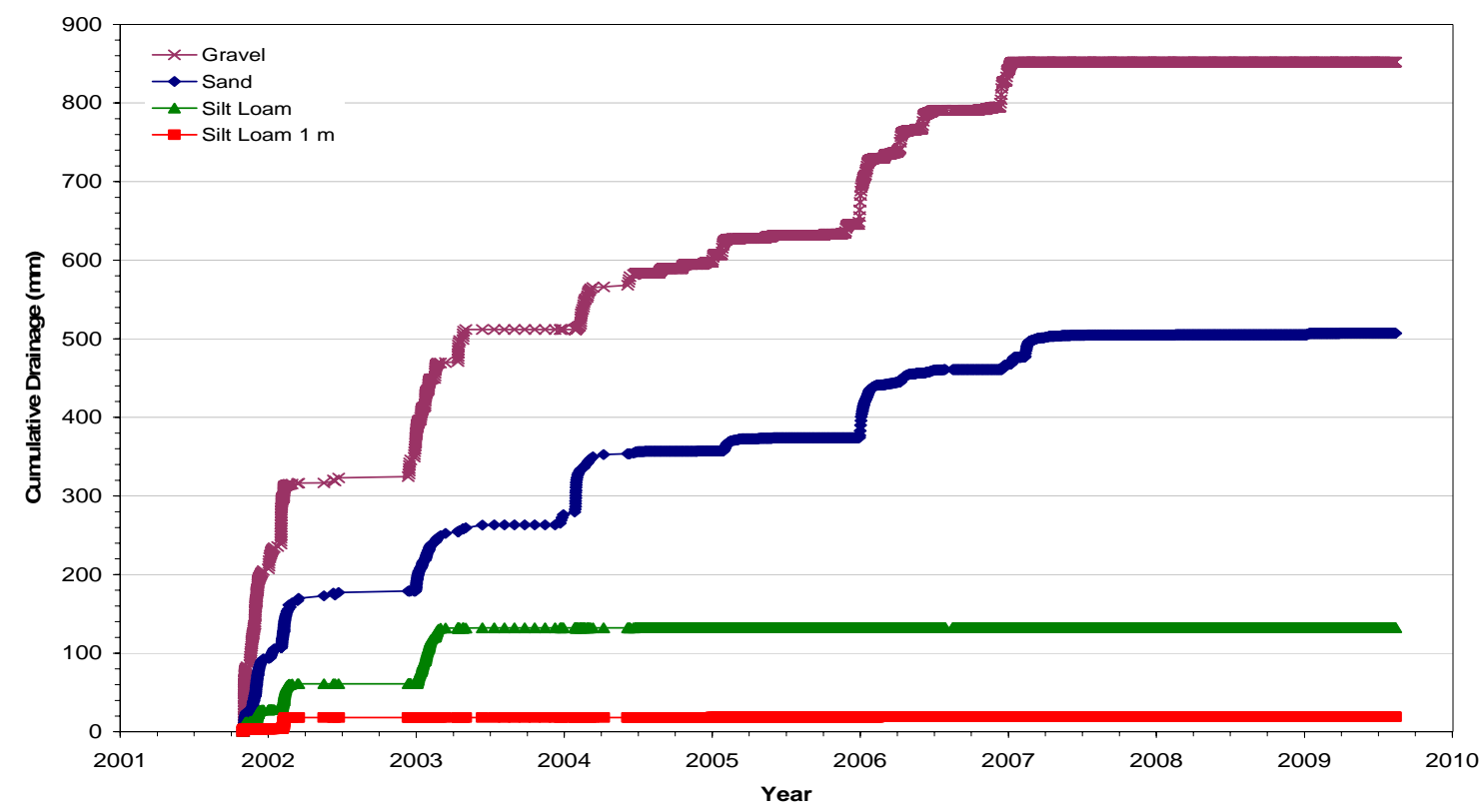

Figure 5.31. Cumulative Drainage Measured at the FLTF Pit Using Water Flux Meters for Silt Loam, Sand, and Gravel Treatments.

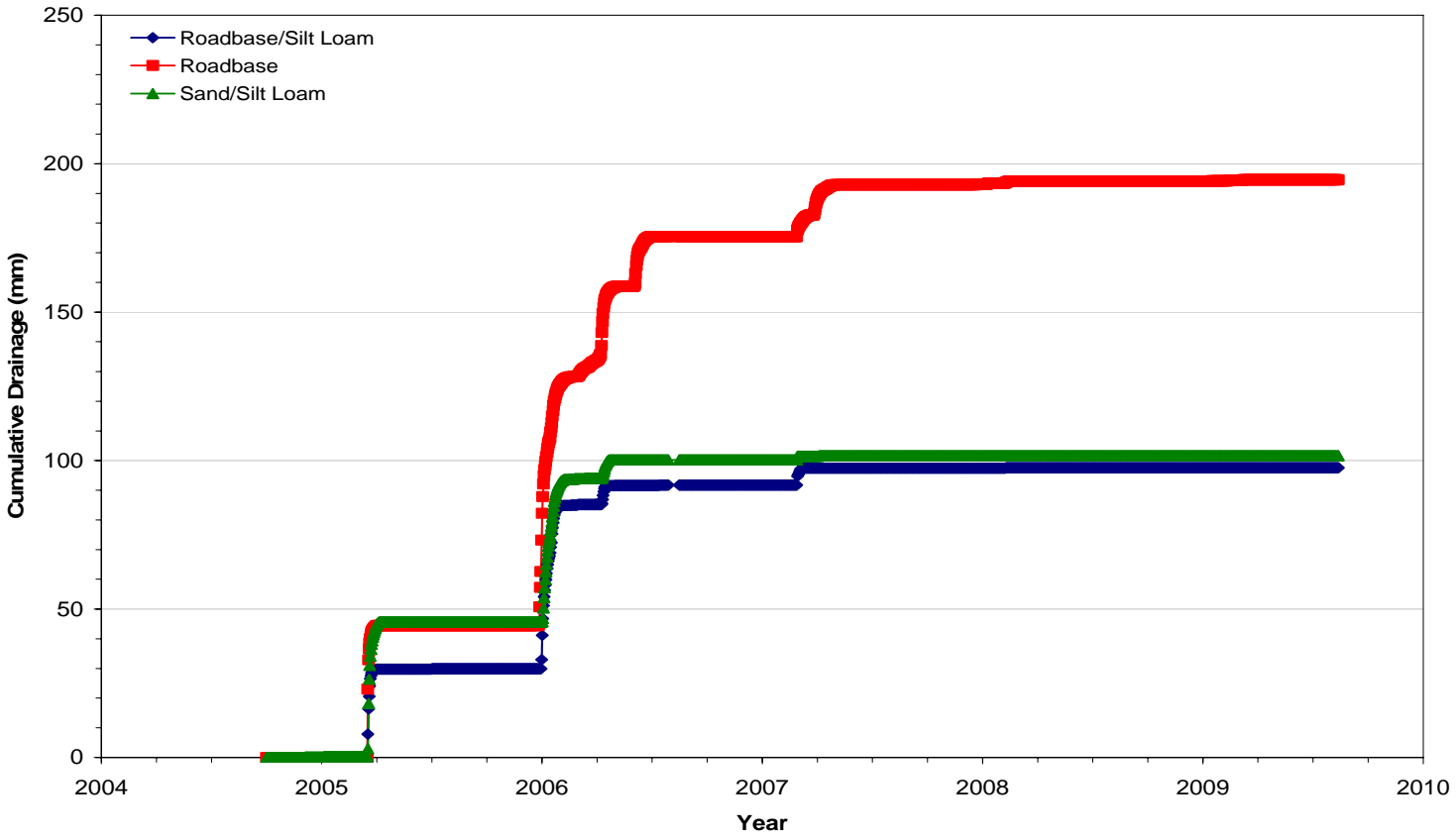

Figure 5.32. Cumulative Drainage Measured at the FLTF Pit Using Water Flux Meters for Road Base/Silt Loam, Sand/Silt Loam, and Road Base Treatments. 


\subsection{Tank Farms}

Single- and double-shell tanks used for radioactive waste storage pose special concerns at the Hanford Site. Characterization of recharge for the surface conditions of these sites has been a subject of great interest. All available evidence suggests that past tank farm management practices of maintaining gravel-covered surface devoid of vegetation maximizes recharge rates and hence increases the rates of transport of leaked contaminants to the groundwater. Several monitoring sites were active in the past at locations adjacent to the B, SX, and TX tank farms (Nichols et al. 2008). These monitoring sites have since been decommissioned owing to inadequate funding for long-term support of these efforts.

PNNL is currently providing recharge monitoring support for an interim cover at the $\mathrm{T}$ farm (Zhang et al. 2009). The interim cover is a polymer that was sprayed over the ground surface. Water that accumulates on the cover is diverted to an adjacent evaporation pond. There are currently four monitoring stations: two under the middle of the cover, one at the edge of the cover, and another located $~ 100 \mathrm{~m}$ away from the edge of the cover that acts as a control. Water contents are being measured at each of these monitoring stations using capacitance and neutron probes. Water potentials are being monitored using heat-dissipation units (HDUs). Water flux meters are also installed at these stations, but they have never functioned properly.

\subsection{East Lysimeter}

As noted by Nichols et al. (2008), a large hole developed adjacent to the 300 East Lysimeter Site in March 2005, presumably because of poor compaction after the site was initially installed. This hole compromised the value of the neutron logging data that were collected within the lysimeter. Nearby neutron probe access tubes in grass and sagebrush areas still had potential value, but access to this general area has become increasingly restrictive due to its designation as a surface contamination area. Therefore the 200 East Lysimeter Site is no longer being monitored. 
[This page intentionally left blank 



\subsection{Conclusions}

The importance of recharge and available measurement techniques were presented. Data collected at several recharge measurement sites in FY 2004 through 2009 are presented and discussed. These data are available for use in refining and improving recharge rate estimates for soils of the Hanford Site, with emphasis on the soils of the Central Plateau. Critical gaps in the knowledge of recharge at the Hanford Site were presented. These listed gaps serve as a guide to assist in prioritizing future Hanford recharge work towards developing more defensible recharge estimates.

The field soil water balance and recharge measurement sites have been monitored over the past several years with a very low level of effort that relies heavily on automated acquisition and uploading of data and periodic review of the data streams. Disruption of funding in FY09 due to the change in site contractors prevented any site visits or data reviews until early February. This funding disruption and a sensor failure at one site that does not have automated data uploading resulted in the loss of several months worth of data from that site (SWL). Problems also occurred at several other sites. Water content sensors at the $300 \mathrm{~N}$ lysimeter were disturbed when a new project was started at that site, but this problem went unnoticed for several months. Two of the weighing lysimeters and the datalogger for these lysimeters at the FLTF have continued to exhibit anomalous behavior and it is speculated that one of the load cells on one of the weighing lysimeters is bad. Although no lysimeter drainage (or recharge) data were compromised, the problems that have occurred this year suggest that a longer-term strategic plan for the FLTF and other water balance and recharge monitoring sites is probably warranted to ensure that high-quality, long-term records of recharge and related water balance data continue to be generated. 
[This page intentionally left blank] 


\subsection{References}

Bacon DH and BP McGrail. 2002. Effect of Design Change on Remote-Handled Trench Waste Form Release Calculations. PNNL-13947, Richland, Washington, Pacific Northwest National Laboratory.

Baldwin M, CE Kellogg and J Thorpe. 1938. "Soil Classification". Soils and Men, U. S. Department of Agriculture: 979-1001.

Campbell MD, GW Gee, MJ Kanyid and ML Rockhold. 1990. Field Lysimeter Test Facility: Second year (FY 1989) test results. PNL-7209, United States.

Chatters JC and KA Hoover. 1992. "Response of the Columbia River fluvial System to Holocene Climatic Change." Quaternary Research 37:42-59.

Cleveland, R. B., W. S. Cleveland, J.E. McRae, and I. Terpenning (1990) STL: A Seasonal-Trend Decomposition Procedure Based on Loess. Journal of Official Statistics, 6, 3-73.

DePaolo DJ, ME Conrad, K Maher and GW Gee. 2004. "Evaporation Effects on Oxygen and Hydrogen Isotopes in Deep Vadose Zone Pore Fluids at Hanford, Washington." Vadose Zone Journal 3:220-232.

Downs JL, WH Rickard, CA Brandt, LL Cadwell, CE Cushing, DR Geist, RM Mazaika, DA Neitzel, LE Rogers, MR Sackschewsky and JJ Nugent. 1993. Habitat Types on the Hanford Site: Wildlife and Plant Species of Concern. PNL-8942, Pacific Northwest Laboratory, Richland, Washington.

Enfield CG and JJC Hsieh. 1971. "Application of Thermocouple Psychrometers to Soil Water Transport." Water Resources Research 7:(5):1349-1353.

Enfield J, JC Hsieh and AW Warrick. 1973. "Evaluation of Water Flux Above a Deep Water Table Using Thermocouple Psychrometers." Soil Science Society of America Proceedings 37:968-970.

Fayer MJ and GW Gee. 2006. "Multiple-Year Water Balance of Soil Covers in a Semiarid Setting." Journal of Environmental Quality 35:366-377.

Fayer MJ and JM Keller. 2007. Recharge Data Package for Hanford Single-Shell Tank Waste Management Areas. PNNL-16688, Pacific Northwest National Laboratory, Richland, Washington.

Fayer MJ, FO Khan, EM Murphy, CW Lindenmeier, JL Downs and BN Bjornstad. 1999. Recharge Data Package for the Immobilized Low-Activity Waste 2001 Performance Assessment. PNNL-13033, Pacific Northwest National Laboratory, Richland, Washington.

Fayer MJ and JE Szecsody. 2004. Recharge Data Package for the 2005 Integrated Disposal Facility Performance Assessment. PNNL-14744, Pacific Northwest National Laboratory, Richland, Washington.

Fayer MJ and TB Walters. 1995. Estimated Recharge Rates at the Hanford Site. PNL-10285, Pacific Northwest Laboratory, Richland, Washington. 
Freeman HD and GW Gee. 1989. Hanford Protective Barriers Program Asphalt Barrier Studies- FY 1988. PNL-6874, Pacific Northwest Laboratory, Richland, Washington.

Gaylord DR and LD Stetler. 1994. "Aeolian-Climatic Thresholds and Sand Dunes at the Hanford Site, South-Central Washington." Journal of Arid Environments 28:(2):95-116.

Gee GW. 1987. Recharge at the Hanford Site: Status Report. PNL-6403, Pacific Northwest Laboratory, Richland, Washington.

Gee GW, MJ Fayer, ML Rockhold and MD Campbell. 1992. "Variations in recharge at the Hanford Site." Northwest Science 66:14.

Gee GW, MJ Fayer, ML Rockhold, PJ Wierenga, MH Young and BJ Andraski. 1994. "Variations in Water Balance and Recharge Potential at Three Western Desert Sites." Soil Science Society of America Journal 58:Pages: 63-72.

Gee GW, DG Felmy, JC Ritter, MD Campbell, JL Downs, MJ Fayer, RR Kirkham and SO Link. 1993. Field Lysimeter Test Facility Status Report IV: FY 1993. PNL-8911, Pacific Northwest Laboratory, Richland, Washington.

Gee GW and TL Jones. 1985. Lysimeters at the Hanford Site. Present Use and Future Needs. PNL5578, Pacific Northwest Laboratory, Richland, Washington.

Gee GW, JM Keller and AL Ward. 2005. "Measurement and Prediction of Deep Drainage from Bare Sediments at a Semiarid Site." Vadose Zone Journal 4:(1):9.

Gee GW, RR Kirkham, JL Downs and MD Campbell. 1989. The Field Lysimeter Test Facility (FLTF) at the Hanford Site: Installation and Initial Tests. PNL-6810, Pacific Northwest National Laboratory, Richland, Washington.

Gee GW, AL Ward, LL Cadwell and JC Ritter. 2002. "A Vadose Zone Water Fluxmeter with Divergence Control." Water Resources Research 38:(8):1141-.

Gee GW, AL Ward, JB Sisson, JM Hubbell, DA Myers and HH Sydnor. 2003a. Hydrologic Characterizations Using Vadose Zone Monitoring Tools: Status Report PNNL-14115, Pacific Northwest National Laboratory, Richland, Washington.

Gee GW, ZF Zhang and AL Ward. 2003b. "A Modified Vadose Zone Fluxmeter with Solution Collection Capability." Vadose Zone Journal 2:627-632.

Hajek BF. 1966. Soil Survey: Hanford Project in Benton County, Washington. BNWL-243, Pacific Northwest Laboratory, Richland, Washington.

Hoitink DJ, KW Burk, JV Ramsdell, Jr, and WJ Shaw. 2005. Hanford Site Climatological Summary 2004 with Historical Data. PNNL-15160, Pacific Northwest National Laboratory, Richland, WA. 
Hsieh JJC, LE Brownell and AE Reisenauer. 1973. Lysimeter Experiment Description and Progress Report on Neutron Measurements. BNWL-1711, Battelle Pacific Northwest Laboratories, Richland, Washington,

Keller JM, CE Strickland, DL Saunders and RE Clayton. 2007. Remediation Decision Support ProjectRecharge Measurement Task FY07 Status Report. Richland, Washington, Pacific Northwest National Laboratory

Kocher AE and AJ Strahorn. 1919. Soil Survey of Benton County, Washington. U. S. Government Printing Office, Washington, D.C.

Last GV, EJ Freeman, KJ Cantrell, MJ Fayer, GW Gee, WE Nichols, BN Bjornstad and DG Horton. 2006. Vadose Zone Hydrogeology Data Package for the 2004 Composite Analysis. PNNL-14702 Rev. 1, Pacific Northwest National Laboratory, Richland, Washington.

Maher K, DJ DePaolo and JN Christensen. 2006. "U-Sr Isotopic Speedometer: Fluid Flow and Chemical Weathering Rates in Aquifers." Geochima et Cosmochimica Acta 70:4417-4435.

Maher K, DJ DePaolo, ME Conrad and RJ Serne. 2003. "Vadose Zone Infiltration Rate at Hanford, Washington, Inferred from Sr Isotope Measurements." Water Resources Research 39:(8):1204-1208.

McCord JT, CA Gotway and SH Conrad. 1997. "Impact of Geologic Heterogeneity on Recharge Estimation Using Environmental Tracers: Numerical Modeling Investigation." Water Resources Research 33:(6):1229-1240.

Murphy EM, TR Ginn and JL Phillips. 1996. "Geochemical Estimates of Paleorecharge in the Pasco Basin: Evaluation of the Chloride Mass Balance Technique." Water Resources Research 32:(9):28532868.

Murphy EM, JE Szecsody and SJ Phillips. 1991. A Study Plan for Determining Recharge Rates at the Hanford Site Using Environmental Tracers. PNL-7626, Pacific Northwest Laboratory, Richland, Washington.

Nichols WE, SK Wurstner and PW Eslinger. 2007. "Vadose Zone-Attenuated Artificial Recharge for Input to a Ground Water Model." Ground Water 45:(4):491-498.

Nichols WE, ML Rockhold, and JL Downs. 2008. Compendium of Data for the Hanford Site (Fiscal Years 2004 to 2008) Applicable to Estimation of Recharge Rates. PNNL-17841. Pacific Northwest National Laboratory, Richland, Washington.

Phillips FM. 1994. "Environmental Tracers for Water Movement in Desert Soils of the American Southwest." 58:(1):15-24.

Phillips SJ, AC Campbell, MD Campbell, GW Gee, HH Hoober and KO Schwarzmiller. 1979. A Field Test Facility for Monitoring Water/Radionuclide Transport Through Partially Saturated Geologic Media: Design, Construction, and Preliminary Description. PNL-3226, Pacific Northwest Laboratory, Richland, Washington. 
Prych EA. 1998. Using Chloride and Chlorine-36 as Soil-Water Tracers to Estimate Deep Percolation at Selected Locations on the U.S. Department of Energy Hanford Site, Washington. Water-Supply Paper 2481, U.S. Geological Survey, Denver, Colorado.

Rickard WH and BE Vaughn Eds. 1988. Chapter 6: Plant Communities: Characteristics and Responses. In Shrub-Steppe, Balance and Change in a Semi-Arid Terrestrial Ecosystem. Elsevier, New York.

R Development Core Team (2009). R: A language and environment for statistical computing. R Foundation for Statistical Computing, Vienna, Austria. ISBN 3-900051-07-0, URL http://www.Rproject.org.

Rockhold ML, MJ Fayer, CT Kincaid and GW Gee. 1995. Estimation of Natural Ground Water Recharge for the Performance Assessment of a Low-Level Waste Disposal Facility at the Hanford Site. PNL-10508, Pacific Northwest National Laboratory, Richland, Washington.

Routson RC, MR Fuchs and WA Jordan. 1988. Recharge Estimate for the Hanford Site 200 Areas Plateau. WHC-EP-0046, Westinghouse Hanford Company, Richland, Washington.

Scanlon BR. 2000. "Uncertainties in Estimating Water Fluxes and Residence Times using Environmental Tracers in an Arid Unsaturated Zone." Water Resources Research 36:(2):395-409.

Scanlon BR, RW Healy and PG Cook. 2002. "Choosing Appropriate Techniques for Quantifying Groundwater Recharge." Hydrogeology Journal 10:18-39.

SCS. 1951. Soil Survey Manual. Handbook No. 18, Soil Conservation Service, U. S. Department of Agriculture, Washington, D.C.

SCS. 1960. Soil Classification, A Comprehensive System, 7th Approximation. Soil Conservation Service, U.S. Department of Agriculture, Washington, D.C.

Sheppard SC, WG Evenden and CR Macdonald. 1998. "Variation Among Chlorine Concentration Ratios for Native and Agronomic Plants." Journal of Environmental Radiation(43):65-76.

Singleton MJ, K Maher, DJ DePaoloa, ME Conrad and PE Dresel. 2006. "Dissolution Rates and Vadose Zone Drainage from Strontium Isotope Measurements of Groundwater in the Pasco Basin,

WA Unconfined Aquifer." Journal of Hydrology 321:(1-4):39-58.

Sisson JB, GW Gee, JM Hubbell, WL Bratton, JC Ritterb, AL Ward and TG Caldwell. 2002. "Advances in Tensiometry for Long-term Monitoring of Soil Water Pressures." Vadose Zone Journal 1:310-315.

Smoot JL, JE Szecsody, B Sagar, GW Gee and CT Kincaid. 1989. Simulations of Infiltration of Meteoric Water and Contaminant Plume Movement in the Vadose Zone at Single-Shell Tank 241-T-106 at the Hanford Site. WHC-EP-0332, Westinghouse Hanford Company, Richland, WA.

Thomas GW and AR Swoboda. 1970. "Anion Exclusion Effects on Chloride Movement in Soils." Soil Science 110:(3):163-166. 
Tyler SW, BR Scanlon, GW Gee and GB Allison Eds. 1999. Water and Solute Transport in Arid Vadose Zones. In Vadose Zone Hydrology. Oxford University Press, New York.

Waichler SR, MS Wigmosta and A Coleman. 2004. Natural Recharge to the Unconfined Aquifer System on the Hanford Site from the Greater Cold Creek Watershed: Progress Report 2004. PNNL-14717, Pacific Northwest National Laboratory, Richland, Washington.

Ward AL, GW Gee and SO Link. 1997. Hanford Prototype-Barrier Status Report: FY 1997. PNNL11789, Pacific Northwest National Laboratory, Richland, Washington.

Ward AL, JK Linville, JM Keller and GH Seedahmed. 2005. 200-BP-1 Prototype Hanford Barrier Annual Monitoring Report for Fiscal Year 2004. PNNL-14960, Pacific Northwest National Laboratory, Richland, Washington.

Wing NR and GW Gee. 1994. The development of surface barriers at the Hanford Site. WHC-SA-2377, Westinghouse Hanford Company, Richland, Washington.

Wing NR, KL Petersen, C Whitlock and RL Burk. 1995. Long-term climate Change Effects Task for the Hanford Site Permanent Isolation Barrier Development Program: Final Report. BHI-00144, Bechtel Hanford, Inc., Richland, Washington.

Wittreich CD and CR Wilson 1991. Use of Lysimeters to Monitor a Sanitary Landfill. Proceedings of the International Symposium on Lysimetery, In Lysimeters for Evapotranspiration and Environmental Measurements, American Society of Civil Engineers.

Zhang ZF, CE Strickland, JG Field, DL Parker. 2009. T Tank Farm Interim Surface Barrier Demonstration - Vadose Zone Monitoring FY08 Report. Pacific Northwest National Laboratory, Richland, Washington. 
[This page intentionally left blank] 


\section{Distribution}

CHPRC

Scott Petersen

PNNL

ML Rockhold

DL Saunders

CE Strickland

SR Waichler

RE Clayton

MJ Fayer

MD Freshley 





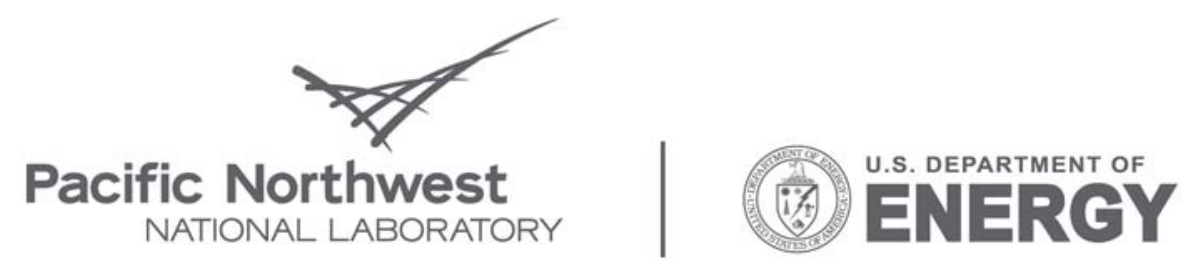

Proudly Operated by Battelle Since 1965

902 Battelle Boulevard

P.O. Box 999

Richland, WA 99352

1-888-375-PNNL (7665)

www.pnl.gov 